\title{
SOLAR APPLICATIONS OF THERMAL ENERGY STORAGE
}

FINAL REPORT

H-CO199-79-753F

by
Charles Lee, Lawrence Taylor, John DeVries, and
Stephen Heibein

January 1979

Contract Number EC-78-C-01-4275

Prepared for:

U.S. Department of Energy

office of Conservation and Solar Applications

HITTMAN ASSOCIATES, INC.

COIUMBIA, MARYLAND 21045

This document is

PUBLICLY RELEASABLE

Gang Stene

Authorizing Official

Date: $7-(9-6)$ 


\section{NOTICE}

This report was prepared as an account of work sponsored by the United States Government. Neither the United States nor the Department of Energy, nor any of their employees, nor any of their contractors, subcontractors, or their employees, makes any warranty, expressed or implied, or assumes any legal liability or responsibility for the accuracy, completeness, or usefulness of any information, apparatus, product, or process disclosed, or represents that its use would not infringe privately owned rights. 


\section{DISCLAIMER}

This report was prepared as an account of work sponsored by an agency of the United States Government. Neither the United States Government nor any agency Thereof, nor any of their employees, makes any warranty, express or implied, or assumes any legal liability or responsibility for the accuracy, completeness, or usefulness of any information, apparatus, product, or process disclosed, or represents that its use would not infringe privately owned rights. Reference herein to any specific commercial product, process, or service by trade name, trademark, manufacturer, or otherwise does not necessarily constitute or imply its endorsement, recommendation, or favoring by the United States Government or any agency thereof. The views and opinions of authors expressed herein do not necessarily state or reflect those of the United States Government or any agency thereof. 


\section{DISCLAIMER}

Portions of this document may be illegible in electronic image products. Images are produced from the best available original document. 


\section{ACKNOWLEDGMENTS}

The authors would like to express their appreciation to all those who provided guidance and assistance in the preparation of this report. In particular we would like to thank Mr. Michael Davis of the Department of Energy who supervised and guided the entire program, and Dr. Henry Curran of Hittman Associates and Dr. Allan Michaels of Argonne National Laboratory who have thoroughly reviewed the draft report and provided us with many valuable comments. Some of Dr. Michaels' comments requiring additional information could not be pursued in the preparation of the final report due to time and budget constraints. Hopefully these comments could be incorporated into the continuing effort of this program. 


\section{TABLE OF CONTENTS}

\section{Page}

NOTICE $\ldots \ldots \ldots \ldots \ldots \ldots \ldots \ldots \ldots \ldots \ldots i_{i}$

ACKNOWLEDGMENT $\ldots \ldots \ldots \ldots \ldots \ldots \ldots \ldots \ldots \ldots \ldots \ldots \ldots \ldots \ldots$

TABLE OF CONTENTS ...................... iv

LIST OF FIGURES $\ldots \ldots \ldots \ldots \ldots \ldots \ldots \ldots \ldots \ldots \ldots \ldots$

LIST OF TABLES ......................... vii

I. EXECUTIVE SUMMARY.................... 1

A. Characteristics of Solar Thermal Energy

Storage.......................

B. Storage Requirements in Solar Applications.. 4

C. Matching Storage Units to Each Application.. 9

D. Development of Preliminary Design Criteria.. 9

II. CHARACTERISTICS OF THERMAL ENERGY STORAGE...... 11

A. Sensible Storage of Thermal Energy in

Liquids......................... 11

B. Sensible Storage in Solids.............21

C. Phase-Change Materials................ 24

D. Thermochemical Energy Storage........... 39

III. STORAGE REQUIREMENTS FOR SOLAR APPIICATIONS..... 51

A. Storage Temperature Range............. 51

B. Energy Storage Capacity Requirements....... 51

C. Length of Storage Time................ 54

D. Energy Losses.................... 54

E. Acceptable Cost.................... 56 
TABLE OF CONTENTS (CONTINUED)

Page

IV. DEVELOPMENT OF PRELIMINARY DESIGN CRITERIA..... 58

A. Matching Storage Units to Solar Components.. 58

B. Development of Preliminary Design Criteria.. 58

V. REFERENCES ......................... 91

APPENDIX A - DATA SHEETS FOR SELECTED STORAGE UNITS. . 97

APPENDIX B - STORAGE REQUIREMENTS FOR SOLAR APPLICA- 


\section{LIST OF FIGURES}

Number

Page

Survey of Available Information for Thermal Storage Units..................... 2

Matching of Thermal Storage Units with SHACOB Paths.................. 5

Matching of Thermal Storage Units with AIPH Paths.......................6 6 SHACOB Path Schematics.............. 7 AIPH Path Schematics............... 8

Sun-Lite Storage Tube.............. 13

Sunwave Energy System Storage Tank........ 14

"SOLATHERM" Solar Storage Tank 2000

Gallon Capacity.................... 15

Owens-Corning 4000 Gallon Fiberglass Water Storage Tank Model D-3................. 17

Solar STOR 2000 Gallon (Total) Storage Tank......................... 18

11 Cross Section of University of New Mexico Solar Pond......................... 20

12 Solid Cross Section of Solar One Thermal

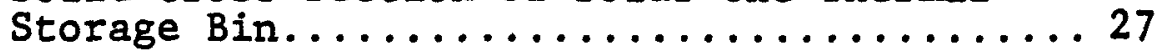

13 Solarmatic Heat Battery.................29

14 Encrusted Conglomerate Valmont Energy Storage Unit........................... 30

15 SOL-AR-TILE With Cross Section.......... 32

16 Rolling Cylinder Thermal Storage Unit ..... 33

17 Add-A-Sun Storage Chamber................ 35 
21.a Seasonal Sulfuric Acid-Water System for Heating and Cooling of Buildings........ 46

21.b Seasonal Sulfuric Acid-Water System for Heating and Cooling of Buildings........ 47

22 Vapor Pressure-Temperature Relationship for a Water-Magnesium Chloride System..... 48

23 Magnesium Chloride Hydrate System Chemical Heat Pump................. 50

24 SHACOB Path Schematics.............. 52

25 AIPH Path Schematics................ 53

26 Matching of Thermal Energy Storage with SHACOB Paths....................... 59

27 Matching of Thermal Energy Storage with AIPH Paths........................ 60

28 Survey of Available Information for Thermal Storage Units................ 61 System........................ 66 


\section{EXECUTIVE SUMMARY}

The objective of this study is to prepare a technology assessment on solar energy systems which use thermal energy storage. The study includes characterization of the current state-of-the-art of thermal energy storage, an assessment of the energy storage needs of solar energy systems, and the synthesis of this information into preliminary design criteria which would form the basis for detailed designs of thermal energy storage. Since the goal of the solar thermal energy storage program is to provide optimum storage units for solar thermal energy systems, this study has focused on storage concepts that are either commercially available or will be commercially available by 1979. The methodology used for this study was as follows:

- Characterize solar thermal energy storage

- Define the storage requirements for each solar application

- Match the storage to each solar application

- Develop the preliminary design criteria. report.

The following sections summarize the results of this

\section{A. Characteristics of Solar Thermal Energy Storage}

A major survey including a literature search, telephone conversations, and computer access to DOE/RECON data bases was conducted. Depending on the storage medium, the storage concepts were divided into four categories:

(1) Liquid storage

(2) Solid storage

(3) Phase-change storage

(4) Thermochemical storage.

The survey results are presented in Section II and Appendix A. The type of avallable information surveyed is also indicated in Figure 1. 


\begin{tabular}{|c|c|c|c|c|c|c|c|c|c|c|c|c|c|c|c|c|c|c|}
\hline $\begin{array}{l}\text { STORAGE } \\
\text { UNITS }\end{array}$ & 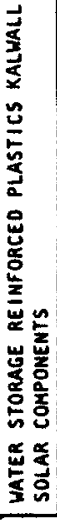 & 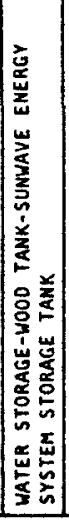 & 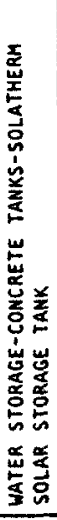 & 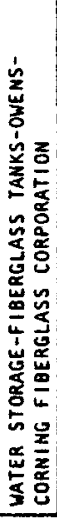 & 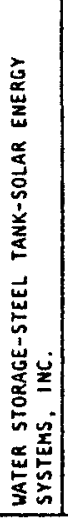 & 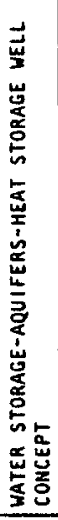 & 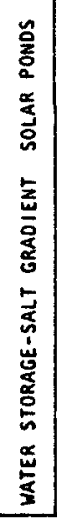 & 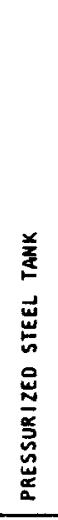 & 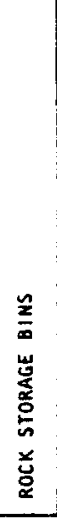 & 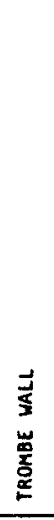 & 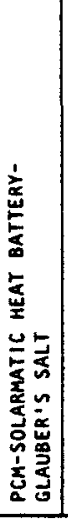 & 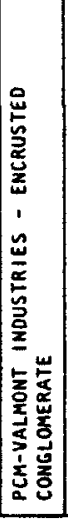 & 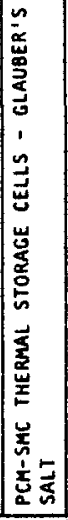 & 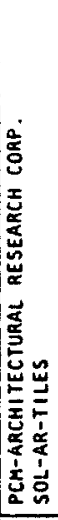 & 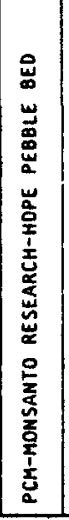 & 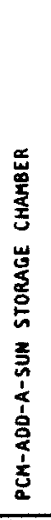 & 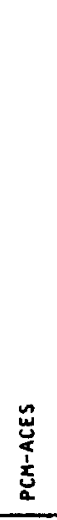 & 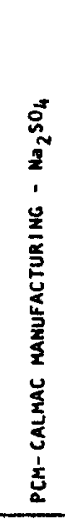 \\
\hline CONTAIMERIZATION & - & $\bullet$ & $\bullet$ & $\bullet$ & - & 0 & - & $\bullet$ & - & $\bullet$ & & 0 & 0 & - & & 0 & o & o \\
\hline STORAGE RATERIAL & $\bullet$ & - & $\bullet$ & $\bullet$ & $\bullet$ & $\bullet$ & o & $\bullet$ & - & - & o & & & - & - & 0 & $\bullet$ & $\circ$ \\
\hline INTERFACE REQUIREMENTS & - & • & - & - & - & 0 & ○ & - & $0^{1}$ & • & & & & 0 & 0 & & 0 & 0 \\
\hline UMIT PERFORMANCE & ० & $\bullet$ & $\bullet$ & - & $\bullet$ & 0 & 0 & 0 & - & 0 & & & & - & & & 0 & o \\
\hline $06 \mathrm{M}$ & $\bullet$ & 0 & - & - & $\bullet$ & & 0 & 0 & - & $\bullet$ & & & & 0 & & & 0 & \\
\hline DESIGN GUIDAMCE & & $e^{3}$ & $0^{3}$ & $e^{3}$ & $0^{3}$ & & $\mathbf{0}$ & 0 & $0^{1}$ & o & & & & 0 & & & 0 & 0 \\
\hline $\cos T$ & - & - & 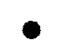 & $\bullet$ & - & & 0 & & 0 & 0 & • & & - & - & 0 & - & 0 & 0 \\
\hline COMMERCIAL AVAILABILITY & Now & NOW & nOW & HOW & Now & NOW & NOW & NOW & NOW & NOW & NOW & 1979 & 1979 & 1979 & $\operatorname{NOW}^{2}$ & Now & NOW & now ${ }^{2}$ \\
\hline
\end{tabular}

1 - Some types, such as thermosyphon designs, are not fully researched.

2 - Storage material is available, not the unit package.

3 - Heat pump interface information is scarce.

Luttle on mo imfonutiom avallable

O SOME InFORMation AVAILABLE

- adequate imformation avallable

Figure 1. Survey of Avallable Information for Thermal Storage Units 


\section{Liquid Storage}

Among various liquids, water remains one of the most useful thermal storage materials because of its low cost, availability, nontoxicity, and high specific heat. The major component of water storage is the container. There are large quantities of commercially available containment vessels suitable for water storage. However, these containers are not necessarily designed specifically for water storage. One example of each type of container material has been selected for illustrative purposes. The selected container materials are reinforced plastics, wood, concrete, fiberglass, and steel.

For seasonal storage, a large underground water tank, aquifer, or salt-gradient solar pond offer attractive alternatives. Depending on the storage temperature, the storage could supply energy either directly to end use or combine with a heat pump to satisfy load requirements.

\section{Solid Storage}

Rock and the Trombe Wall were selected as typical examples of solid storage. Rock is one of the most useful solid storage media because of its abandance, low cost, long life, and favorable heat transfer characteristics when coupled with air heating collectors. Ample experience and knowledge is available for constructing rock storage in space heating applications. The Trombe Wall is an example of thermal mass storage that can be used for passive systems or active systems using forced convection over the surface of the wall. These storage methods are seldom found on the commercial market. Depending on each application, storage can be more cost effective to build on-site than to purchase as a unit.

\section{Phase-Change Storage}

In solar thermal storage applications, phase-change materials have two potentlal advantages over solid or liquid sensible storage materials. These are:

(a) The energy density (Btu/Ib or $B t u / f t^{3}$ ) for a given temperature swing across phase-change temperature can be higher. 
(b) The phase-change materials, having the ability to store thermal energy within a narrow temperature range, act as a temperature regulator by storing or releasing thermal energy at phase-change temperature.

The selected phase-change storage methods that are commercially available now or will be available by 1979 have been indicated in Figures 1,2 , and 3.

The sodium sulfate pebble of Calmac Manufacturing Corporation is a solid-to-solid transformation material storing thermal energy at a temperature range of 400 to $600^{\circ} \mathrm{F}$. The heat battery of Solarmatic, Inc., the encrusted conglomerate of Valmont Industry, and the thermal storage celis of Solar Marketing, Inc., are all using Glauber's salt as the thermal energy storage material, changing phase at approximately $90^{\circ} \mathrm{F}$.

Add-A-Sun of Addison Products Company is using "slack wax" as the energy storage material changing phase at $115^{\circ} \mathrm{F}$. Monsanto Research Corporation has used the high density polyethylene (HDPE) pellets as the storage material changing phase at $266^{\circ} \mathrm{F}$. An interesting product for passive design is Sol-Ar-Tile of Architectural Research Corporation. SolAr-Tile uses a eutectic mixture with Glauber's salt, and can be mounted as ceiling tile operating at the phase-change temperature of $73^{\circ} \mathrm{F}$.

\section{Thermochemical Storage}

The development of thermochemical storage is st1ll in the beginning stage. No example has been selected for developing preliminary design criteria. The sulfuric acidwater system and the magnesium chloride-dihydrate system discussed in Section II are selected for 11lustrative purpose only.

\section{B. Storage Requirements in Solar Applications}

The solar applications studied were the paths indicated on DOE's program. Figure 4 shows the solar heating and cooling of buildings (SHACOB) path schematics, and Figure 5 represents the agricultural and industrial process heat (AIPH) path schematics. On these path schematics the potential thermal storage locations within each path have been indicated. The requirements of storage in solar applications were characterized by the following evaluating criteria: 


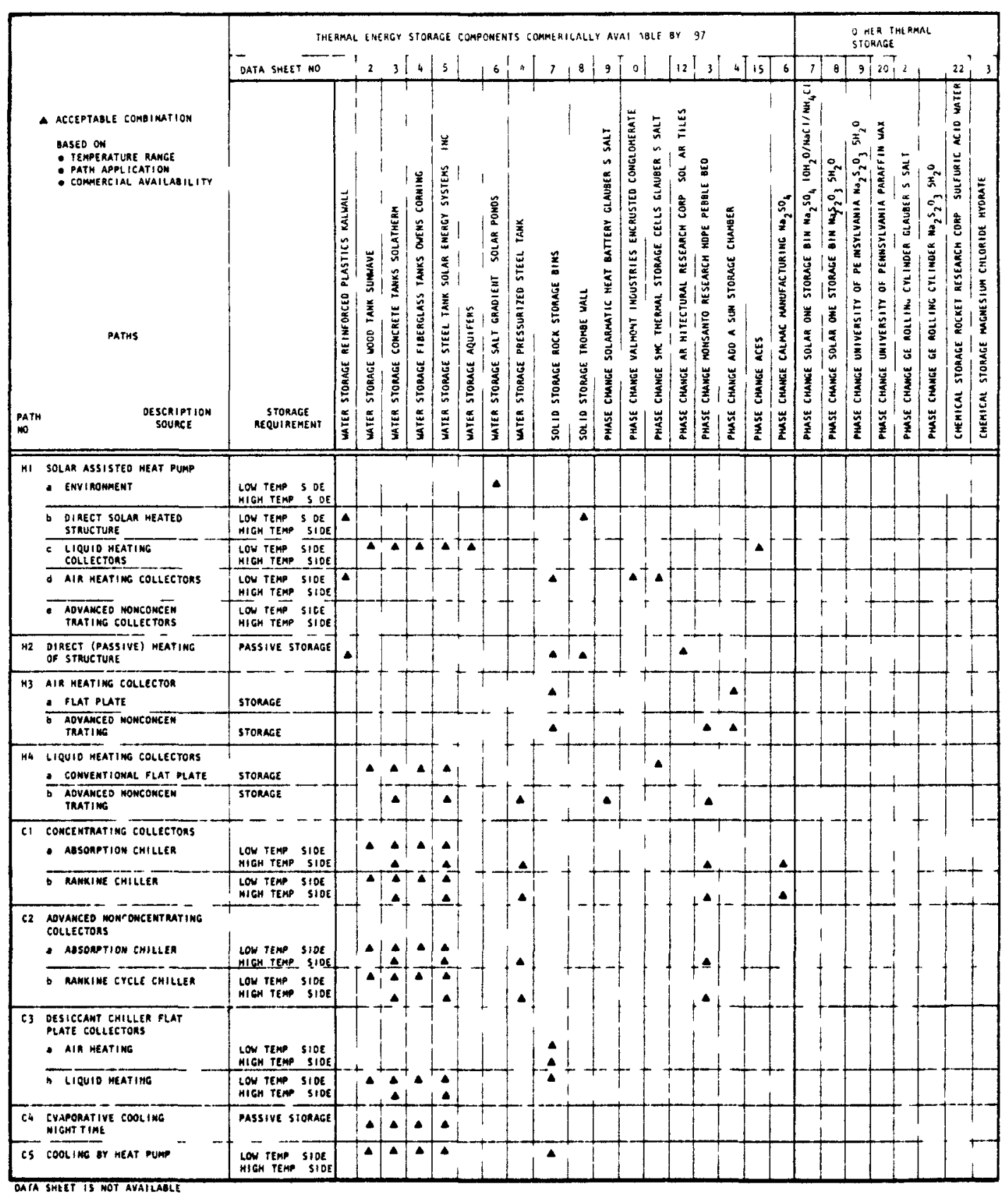

Figure 2. Matching of Thermal Storage Units With SHACOB Paths 


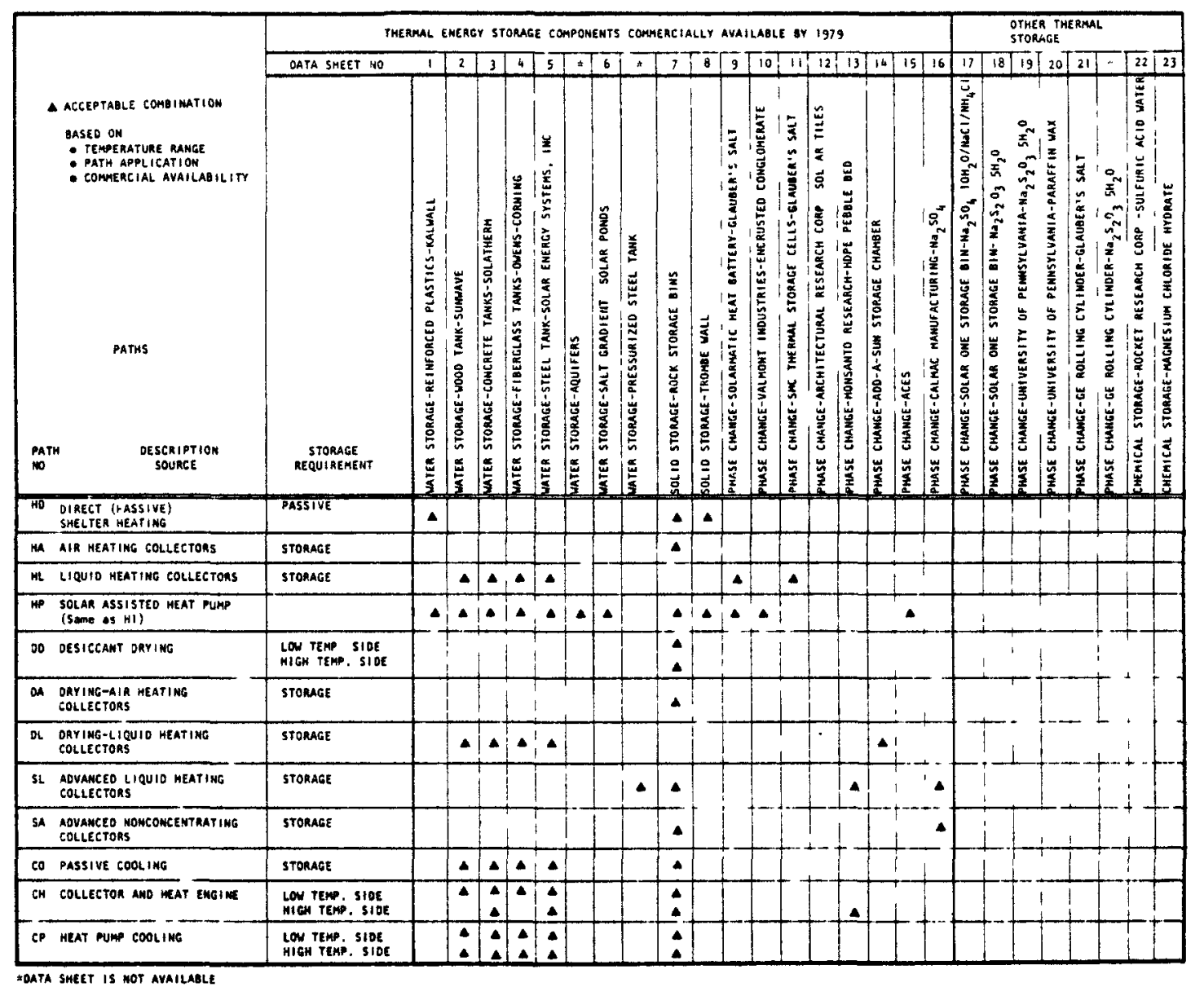

Figure 3. Matching of Thermal Storage Units With AIPH Paths 
PATH DESCRIPTION/SOURCE

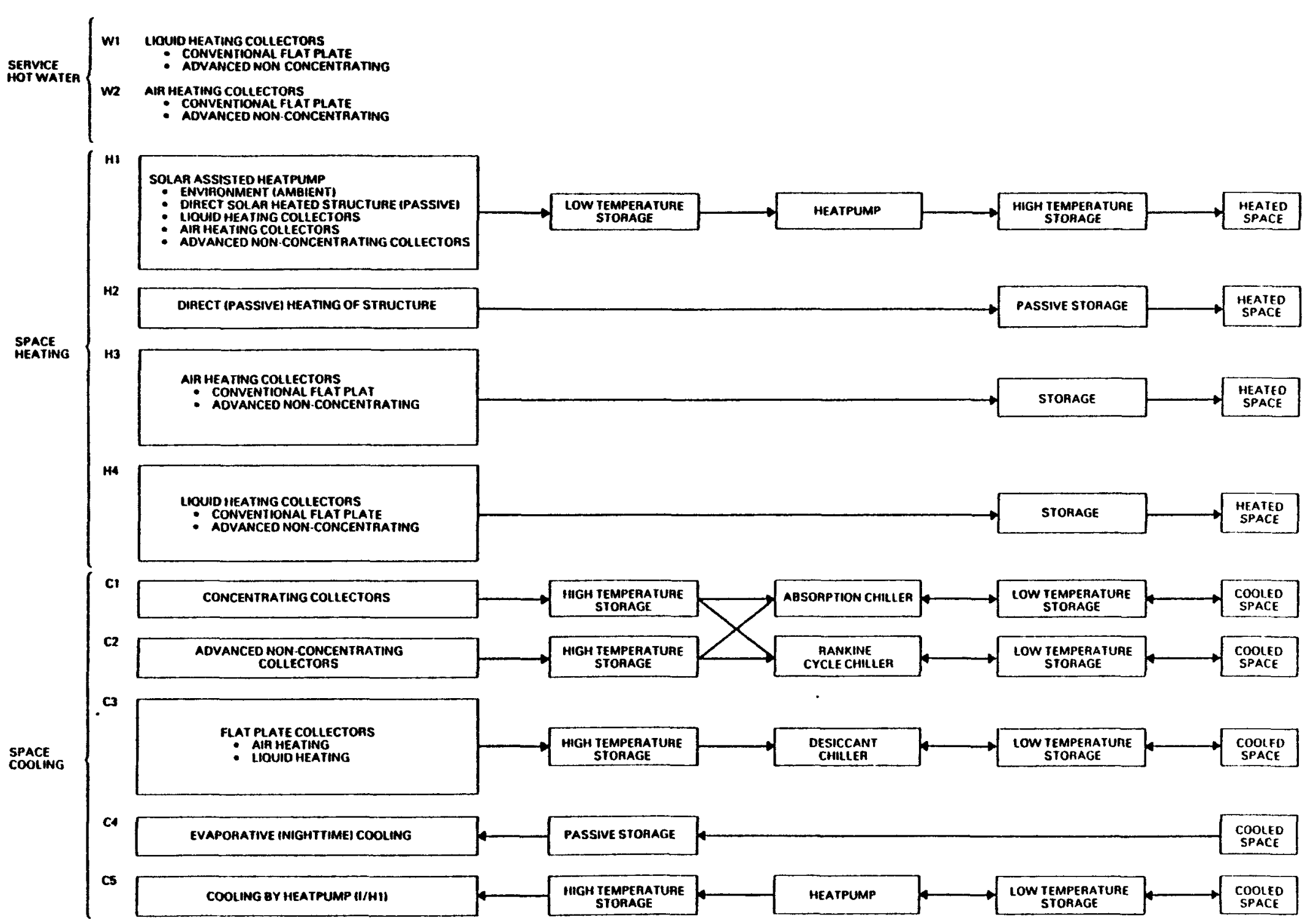

Figure 4. SHACOB Path Schematics (1) 
PATH DESCRIPTION

THEAMAL STORAGE

CONDITIONING

THEAMAL STORAGE

END USE

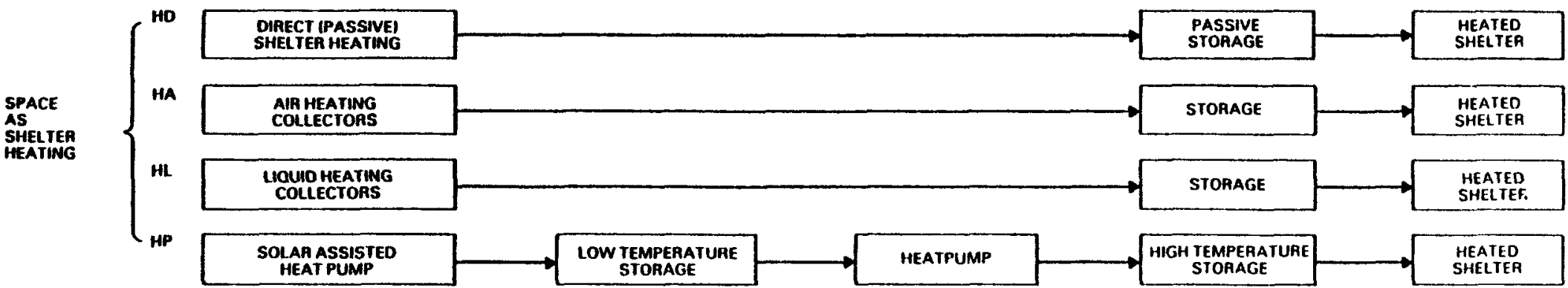

DAYING

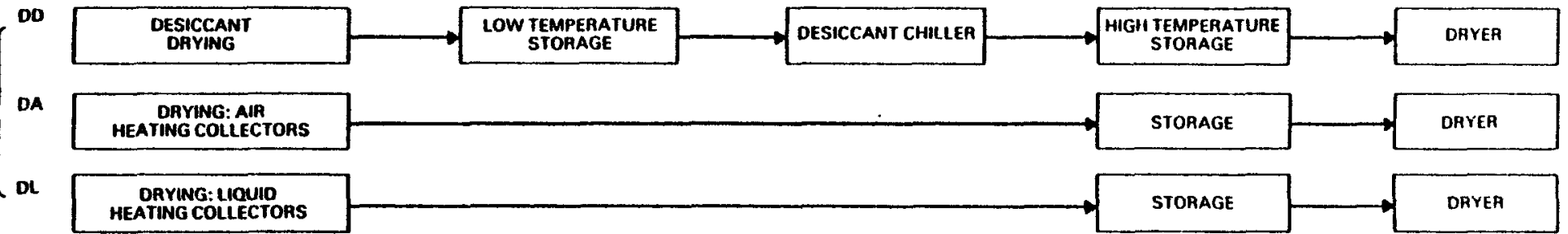

$\infty$
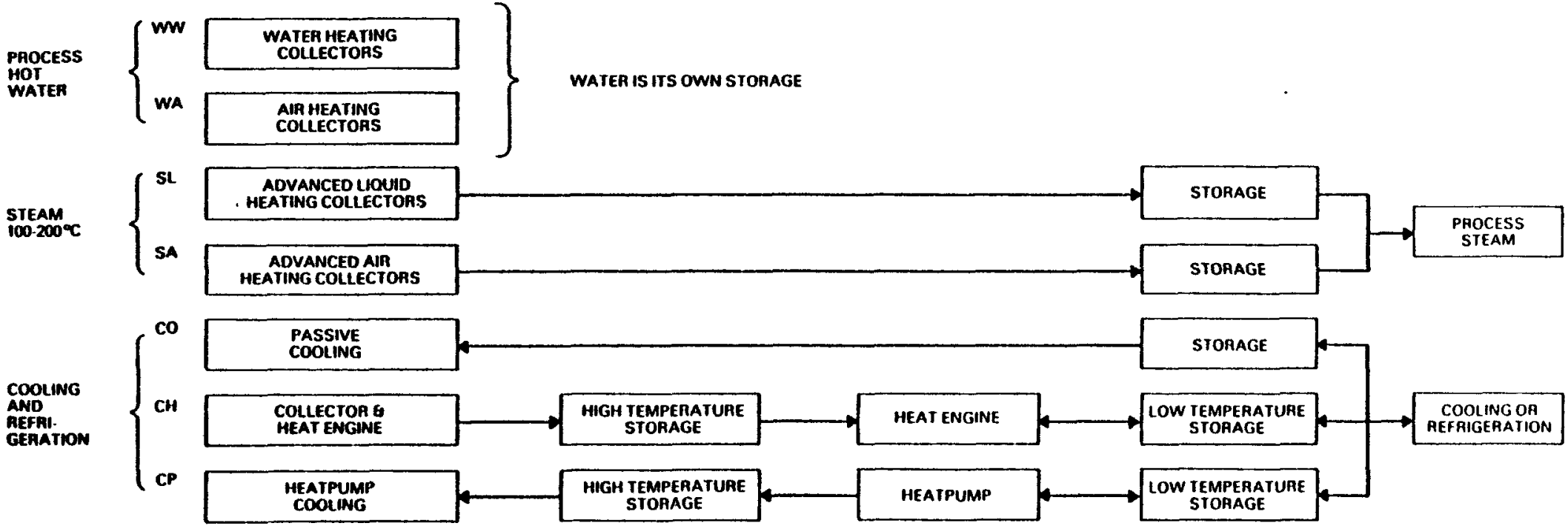

Figure 5. AIPH Path Schematics (1) 
(1) Storage temperature range

(2) Energy storage capacity

(3) Length of storage time

(4) Charge time per cycle

(5) Discharge time per cycle

(6) Thermal energy losses

(7) Acceptable cost level.

The results are presented in Section III and Appendix $B$.

C. Matching Storage Units to Each Application

Potentially attractive energy storage alternatives were identified by matching the characteristics of the storage units with the storage requirements in each application. The main criteria used for matching were commercial availability, temperature range, and path application. The results are presented in Figures 2 and 3 cited above.

\section{Development of Preliminary Design Criteria}

A selected number of storage applications from Figures 2 and 3 have been developed into preliminary design criteria. In these criteria, the following information was discussed:

(1) Storage type, material, stage of development, and container type

(2) Interface requirements

(3) Storage performance

- Operating principle

- Temperature range

- Storage requirements

- Charge rate

- Discharge rate

- Thermal energy 
(4) Operation and maintenance

(5) Cost

(6) Other design considerations.

The goal of the preliminary design criteria is to provide first-cut information showing the limitation in a path application. The results are presented in Chapter IV. 


\section{CHARACTERISTICS OF THERMAL ENERGY STORAGE}

The purpose of this chapter is to identify the characteristics of the major available thermal energy storage units. Depending on the storage medium the storage units are divided into four major types: liquid, solid, phasechange, and thermochemical storage. Selected thermal energy storage for each category is discussed. The characteristics of each selected storage alternative are presented in Appendix $A$.

\section{A. Sensible Storage of Thermal Energy in Liquids}

Since water is the dominating material in liquid storage, only water storage will be discussed. Because of its low cost, availability, nontoxicity, and high relative specific heat, water is regarded as one of the most useful thermal storage materials currently available. At the present stage of development, the storage tanks and associated ancillary equipment (pumps, pipes, heat exchangers, valves, controls, etc.) are readily available as off-theshelf items. Also, the professionals and skilled tradespeople who are involved in the design and construction of water systems are likely to be familiar with water-handling technology and its associated hardware.

Along with the advantages are some associated disadvantages to using water as a thermal energy storage medium. Water causes chemical and electrochemical corrosion. Either corrosion-inhibiting materials must be added to the water, or container materials which resist corrosion must be used. In cases where the storage vessel may be subjected to freezing temperatures, provision must be made for draining the tank, preventing the water from freezing by adding thermal energy from an auxiliary source and insulating the tank, or adding anti-freeze to the water.

\section{The Thermal Storage Characteristics of Water}

Water has a higher heat capacity than any other substance except hydrogen (2). Its specific heat in the temperature range 32 to $212^{\circ} \mathrm{F}$ is essentially $1 \mathrm{Btu} / \mathrm{Ib}-{ }^{\circ} \mathrm{F}$. Water has a latent heat of fusion of $144 \mathrm{Btu} / \mathrm{lb}$ at $32^{\circ} \mathrm{F}$, and a latent heat of vaporization of $947.4 \mathrm{Btu} / \mathrm{Ib}$ at $212^{\circ} \mathrm{F}$ at 14.7 psia. 
A water system storing 250,000 Btu in the temperature range 110 to $160^{\circ} \mathrm{F}$ would require 5000 lbs of water occupying approximately 82 cubic feet of space (4'x $\left.4^{\prime} x 5.1^{\prime}\right)$. Expressing this on a per-unit basis, one cubic foot of water can store about 62 Btu for every Fahrenheit degree increment.

\section{Water Storage in Containers}

There is a wide variety of commercially available vessels suitable for water storage. A recent issue of Solar Engineering lists 14 manufacturers of steel tanks and 17 manufacturers of plastic or fiberglass tanks (3). There are undoubtedly many more. To try to present information on all the available containment vessels is not necessary. A commercially available storage vessel was selected to represent each type of construction material and its characteristics.

a. Reinforced Plastics. The Solar Components Division of the Kalwall Corporation manufactures a standard line of water storage tanks using a fiberglass-reinforced plastic $(4,5)$. The containers are marketed under the name "Sun-lite Storage Tube" and are available in the standard sizes of $3,6,9$, and 18-cubic feet (see Figure 6). They were designed as combined solar collectors and thermal storage units, with passive applications in mind. Ambient room air circulates over plastic tubes filled with hot water. With a temperature rise of $40^{\circ} \mathrm{F}$, the 18 cubic-foot unit stores $44,080 \mathrm{Btu}$. For additional details refer to Data Sheet 1 in Appendix $A$.

b. Wood Tanks. Acorn Structures, Inc., is currently marketing, in kit form, a cylindrical tank constructed of 3/8inch exterior plywood reinforced with galvanized steel bands $(6,7)$. The tank, shown in Figure 7 , supports an inner viny 1 liner. Insulation is provided by a 3-1/2 inch fiberglass batt on the vertical section and on the top of the tank. A combination of 3 inches of vermiculite and 1 inch of styrofoam insulate the bottom of the tank. Tempered hardboard 1/8inch thick surrounds the insulation. The tank is rated to $160^{\circ} \mathrm{F}$. Using an operating range of 110 to $160^{\circ} \mathrm{F}$, the 2000 gallon tank will store 815,507 Btu of usable thermal energy. For additional details refer to Data Sheet 2 in Appendix A.

c. Concrete Tanks. The Solatherm Corporation is currently marketing rectangular solid precast concrete storage tanks for hot water storage in 1000-, 1500-, 2000-, and $2500-$ gallon capacities $(8,9)$. The tank consists of a reinforced concrete shell with foam insulation and a waterproof liner (see Figure 8). The tank is designed to be buried. The standard insulation supplied with the tank has an R-value of 18 . The tank has a rated operating temperature for hot water storage of $210^{\circ} \mathrm{F}$. Allowing for a tem- 


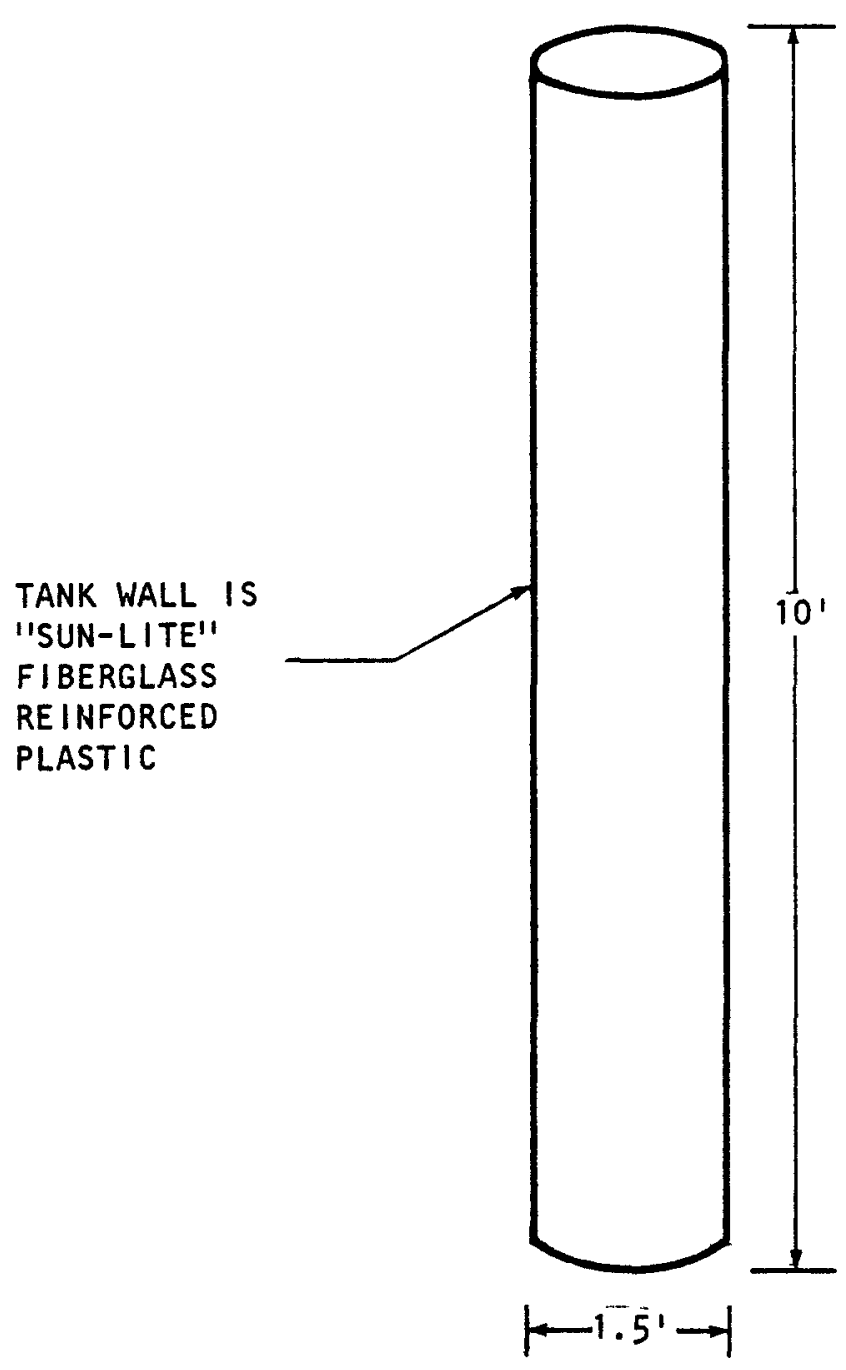

Figure 6. Sun-Lite Storage Tube $17.67 \mathrm{ft}^{3}$ 


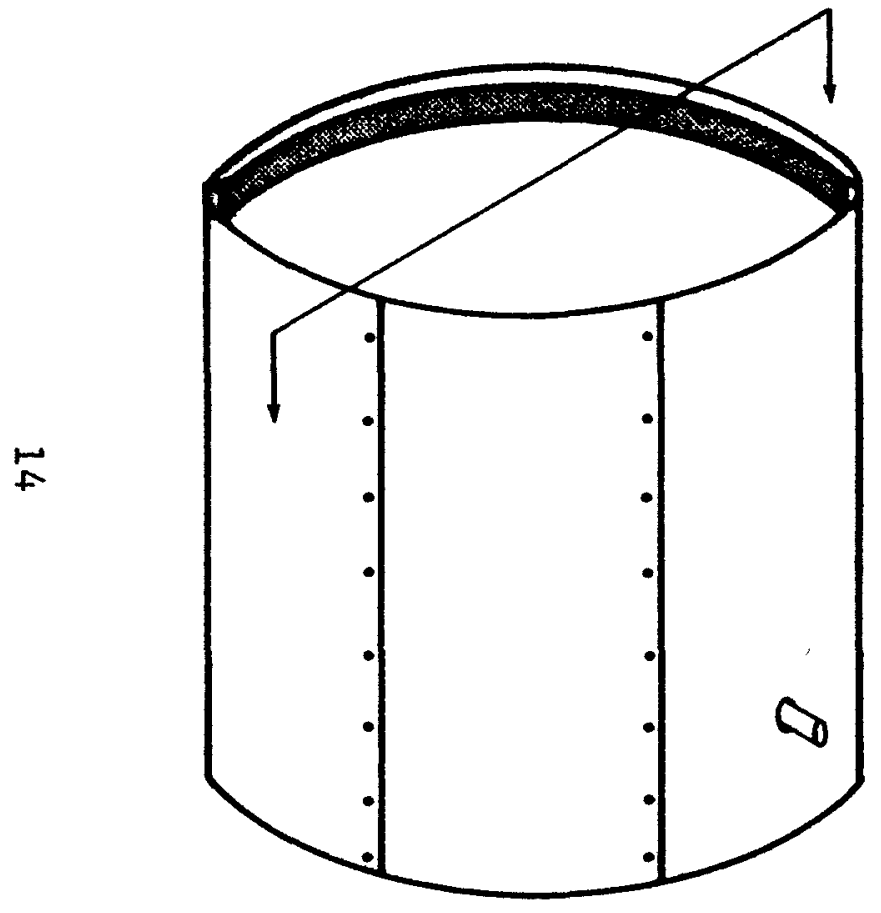

A. FREE STANDING TANK

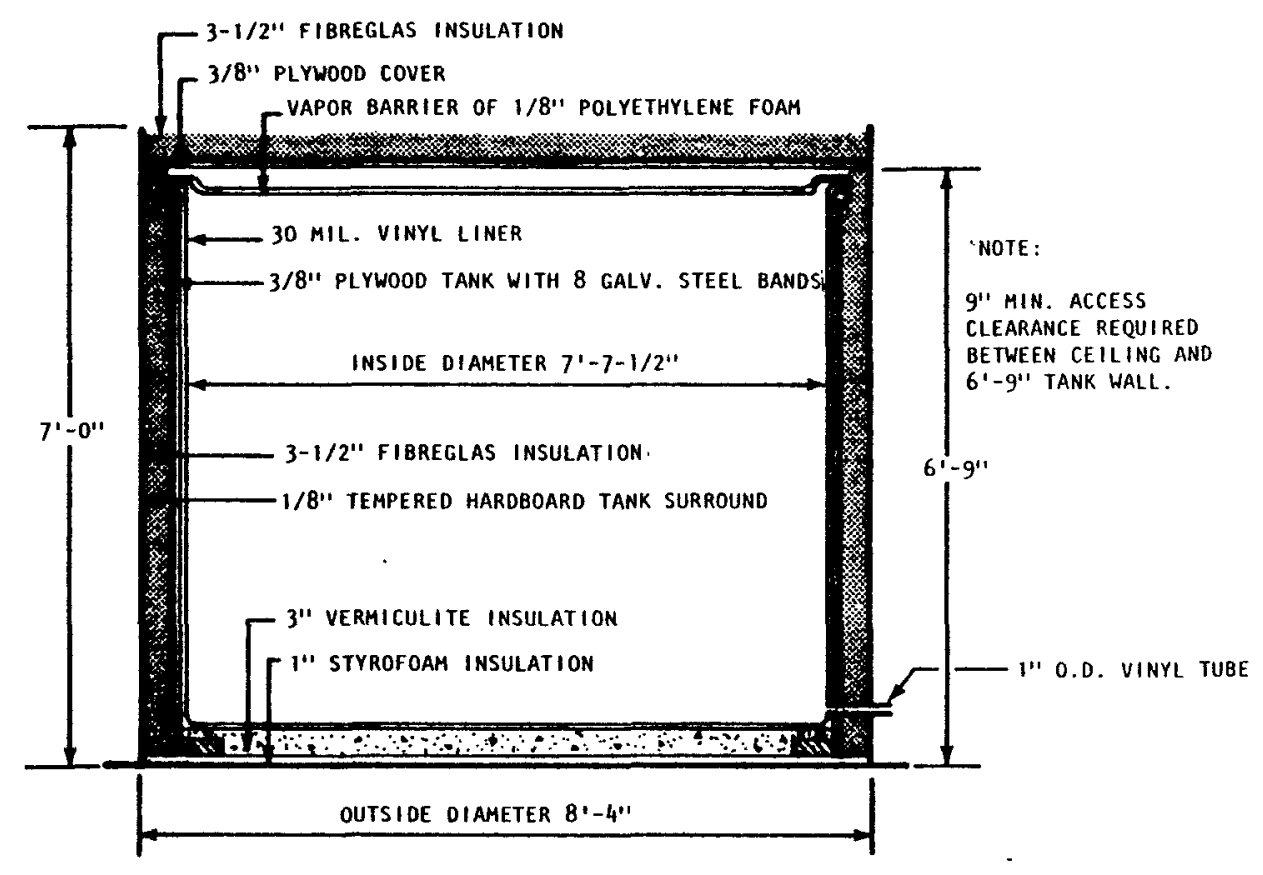

B. SECTION THROUGH StORAGE TANK

Figure 7. Sunwave Energy System Storage Tank 


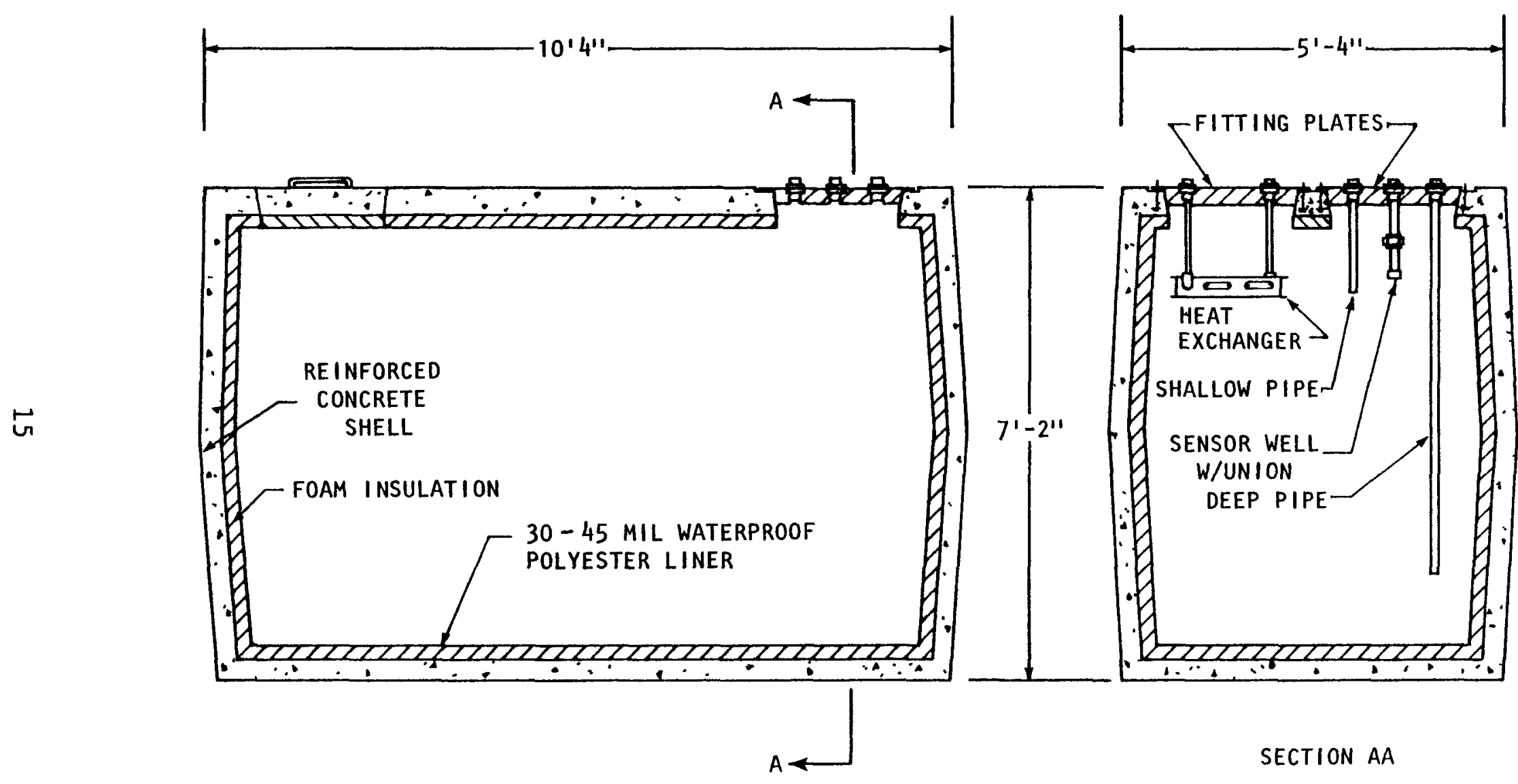

Source: SOLATHERM Corp.

Figure 8. "SOLATHERM" Solar Storage Tank 2000 Gallon Capacity 
perature swing of $100^{\circ}$ ( 110 to $210^{\circ} \mathrm{F}$ ), the 2000 -gallon tank will store about 1.6 million Btu of usable thermal energy. For additional details see Data Sheet 3 in Appendix A.

d. Fiberglass Tanks. The Owens-Corning Fiberglass Corporation manufactures a complete line of fiberglass tanks suitable for underground hot water storage (10). The tanks are available in standard sizes ranging from 550 gallons to 48,000 gallons (see Figure 9). The standard tanks are rated up to $150^{\circ} \mathrm{F}$ using the standard buried configuration with pea gravel backfill. An insulating backfill must be used to control thermal energy 1oss. A material such as K-Crete is recommended as it has the desired backfill characteristics for the tank and the insulating value of 1 inch of fiberglass for each foot of the material used (11). The tanks are also available with a high-temperature biphenol resin which raises the maximum sustained storage temperature rating to $180^{\circ} \mathrm{F}$ using the pea gravel backfill. Refer to Data Sheet 4 in Appendix $A$.

e. Steel Tank Storage. Solar Energy Systems, Inc., manufactures a standard line of steel tanks for the underground storage of solar heated water (12). The tanks, shown in Figure 10, are standard steel tanks such as those used for underground gasoline storage. They are available in sizes of 1,000 to 10,000 gallons of capacity. The tank is sold with an anticorrosive phenolic lining and 2 inches of polyurethane insulation on the outside. The tank is divided into three sections; two are for storage and one serves as a manhole area and dry area for the pumps, piping, and differential thermostats. The primary storage section is for solar-heated fluids, while the secondary storage section can be equipped with an immersion-type electric heating element. This solar energy storage unit, with an electric resistance backup, is designed to provide total hot water and space heating requirements. Water up to $200^{\circ} \mathrm{F}$ can be stored in the tank. For additional details refer to Appendix A, Data Sheet 5 .

\section{Hot Water Storage in Aquifers}

Recently, there has been considerable interest in the technical community in using aquifers as storage reservoirs for heated water in the moderate-to-high temperature range $\left(140\right.$ to $\left.400^{\circ} \mathrm{F}\right)$. An aquifer is defined as an underground stratum or zone that is water bearing (13). In order to store hot water in an aquifer, a well is drilled down from the surface to the aquifer. This well is then used to force the heated water into the aquifer. When the hot water is needed, it is pumped out of the aquifer through the well. Two wells can be used, one for injecting and one for withdrawing the hot water. 


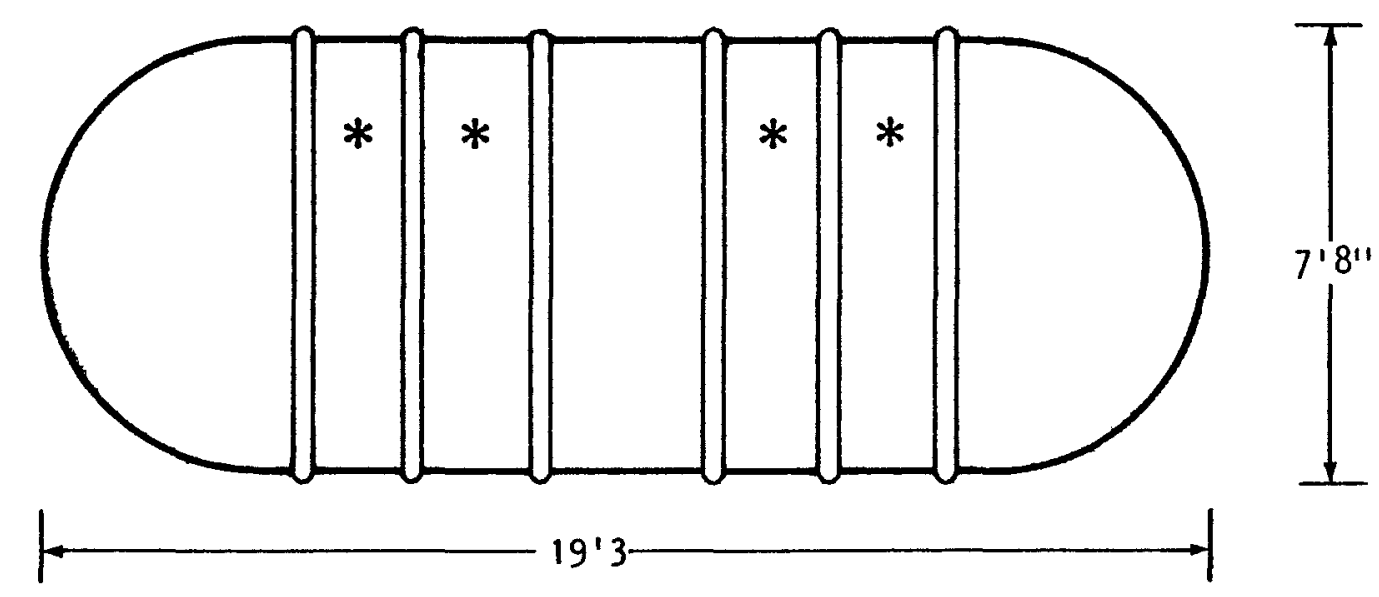

LEGEND

4" NPT STANDARD

FITTING POSITIONS

Figure 9. Owens-Corning 4000 Gallon Fiberglass Water Storage 


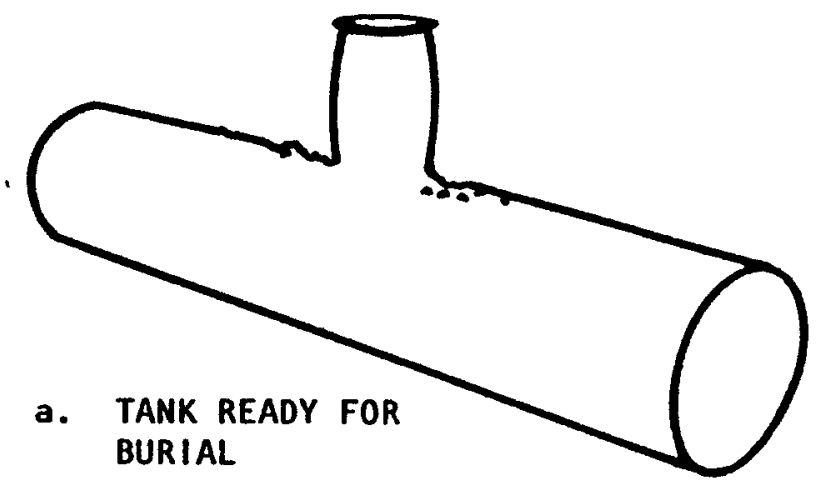

BURIAL

MANHOLE COVER
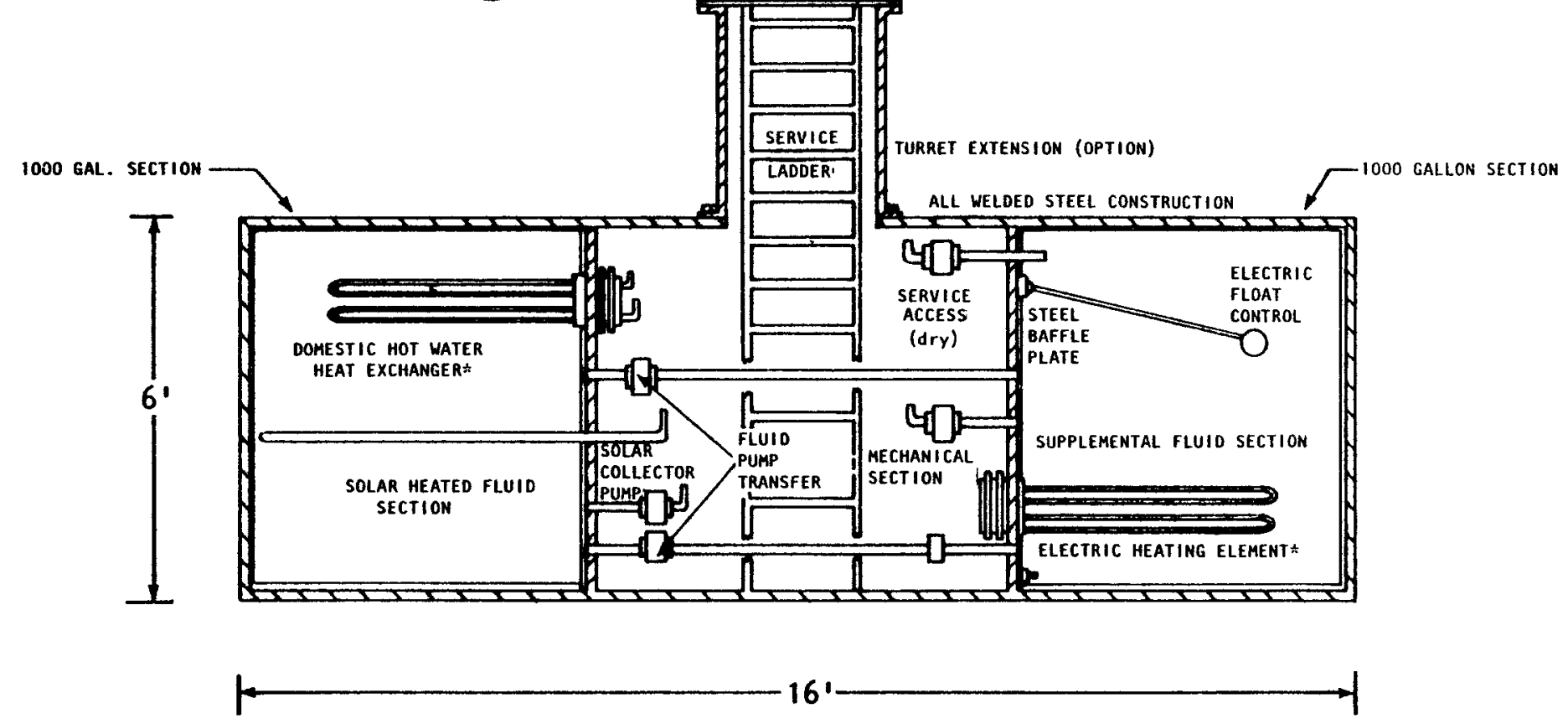

b. CROSS SECTION OF STORAGE TANK

SOURCE: SOLAR ENERGY SYSTEMS, INC.

Figure 10. Solar STOR 2000 Gallon (Total) Storage Tank 
A test of this concept has been performed by the Water Resources Research Institute of Auburn University near the Alabama Power Company's Barry Steam Plant (14). An injection well was drilled 160 feet below the surface 30 feet into the chosen aquifer. Two million gallons of heated water $\left(97^{\circ} \mathrm{F}\right)$ were stored for 36 days. The calculated energy recovery factor was 68 percent. For commercialization of the hot water storage well, further research on ground water impact to environment is needed.

\section{Hot Water Storage in Salt Gradient Solar Ponds}

A body of water exposed to sunlight will absorb a large amount of solar energy through the course of the year, but the water temperature tends to remain below that of the daytime ambient air. Convection currents in the body of water convey the absorbed energy to the surface, where it is quickly lost. It was observed that certain naturally occurring salty lakes had bottom temperatures substantially higher than their surface temperatures. It was found that these lakes had nonuniform vertical distribution of salts resulting in a vertical density gradient. These density gradients are nonconvective and prevent circulation. The solar flux (in the visible and ultraviolet wave lengths) is absorbed in the bottom of the lake or pond. Because circulation is cut off and because water is a poor conductor of thermal energy and opaque to infrared reradiation, the solar thermal energy is effectively trapped.

Such a pond was built at the University of New Mexico in 1975 (15). The pond was constructed with a top diameter of 492 feet, a depth of 8.2 feet, and a bank angle of $34^{\circ}$ from horizontal (see Figure 11). The total capacity of the pond was 8123 cubic feet, with an average storage capacity of 4592 cubic feet. The pond was created using sodium chloride as the salt. A convective layer 71-inches thick containing high-salinity brine by weight was established. gradient region 28 -inches thick was established. Peak recorded temperature was $196^{\circ} \mathrm{F}$ on August 6, 1977; minimum temperature was $88^{\circ} \mathrm{F}$ recorded on January 30,1977 . Heat extraction can be accomplished by pumping heated brine in the convective layer through a heat exchanger and flowing back in a closed loop system. For additional details refer to Data Sheet 6 in Appendix A. 


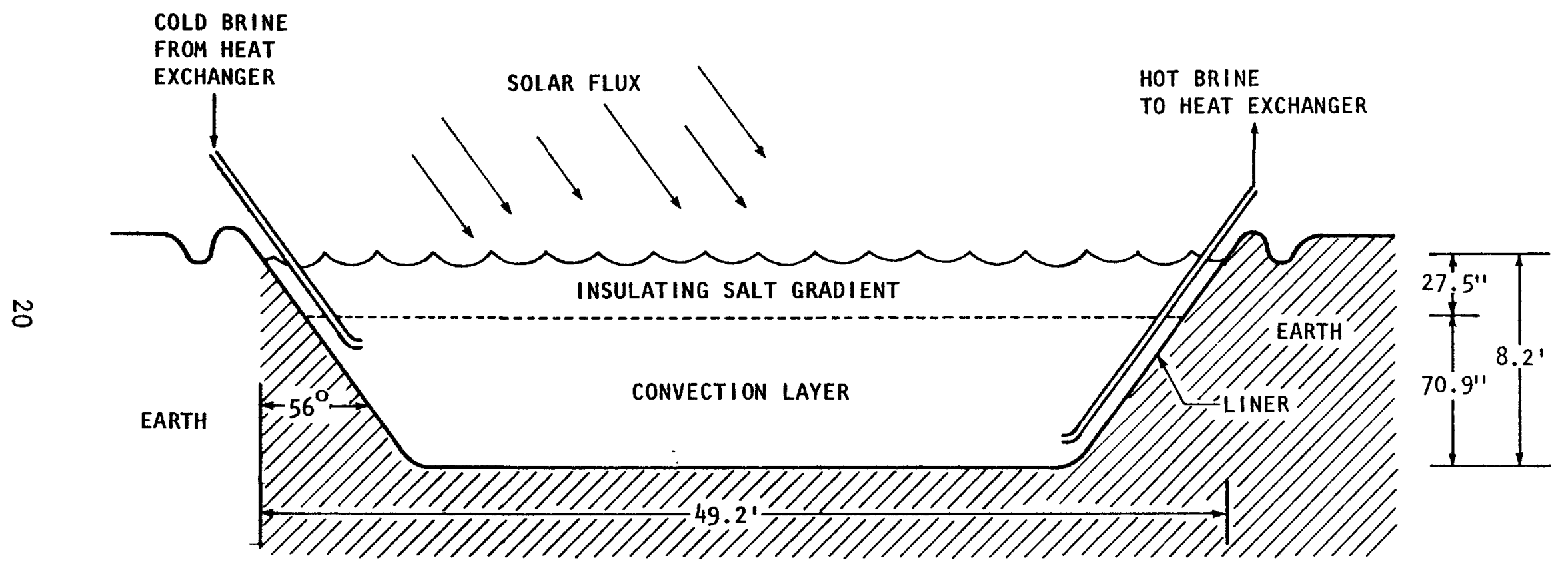

Figure 11. Cross Section of University of New Mexico Solar Pond 


\section{B. Sensible Storage in Solids}

\section{Rock Storage}

Rock storage was one of the earliest methods used in solar applications; it remains popular in residential construction. The popularity of this low-technology method stems from the fact that rock storage, when used in an air system, offers the following benefits:

(a) High storage capacity per unit cost

(b) Plentiful storage medium in nature

(c) Container/system leaks present little problem because air leaks are safe

(d) Corrosion problems are eliminated

(e) Container can be constructed of common building materials

(f) Excessive insulation is not needed because of low conductivity of the rock

(g) Temperature stratification in rocks allows for heat removal at temperatures greater than the average temperature for the rock bed

(h) Need for heat exchangers is eliminated

(i) System requires little or no maintenance

(j) Lifetime of system is commensurate with that of building.

Rock storage units are not without their drawbacks. The most common problems of rock storage are:

(a) Low storage capacity per unit volume

(b) Systems are not easily interfaced with domestic hot water heating systems

(c) Airborne dust and particulate matter can result from using rocks that have not been properly cleaned 
(d) Care must be taken to insure uniform size of rocks to avoid having smaller rocks fill in the voids between larger rocks, thus restricting air flow.

Few commercial rock storage units exist today because it is less expensive to have contractors construct the storage bin on-site than to have the containers factoryconstructed, shipped, and installed. This is because no special tools, materials, or quality control are needed for the construction of rock storage units. Ample experience and knowledge exist for estimating performance of and constructing rock storage units for domestic space heating systems. Further study is needed of unit applicability for annual storage, high-temperature storage, and heat pump assistance. Commercialization of any of the aforementioned applications is restrained only by testing and cost studies, since the equipment and technology needed already exist. Some theoretical work is being done on high-temperature and large-scale storage in rocks; as yet, however, little has been done in the way of constructing and testing actual systems $(16,17,18,19)$. For additional details see Data Sheet 7 in Appendix A.

\section{Thermal Mass Storage}

Thermal mass storage can be one of the simplest methods of storing solar radiation because the storage medium can also be the collector. These systems can be passive, utilizing natural convective currents and/or radiation, or they can be active, using forced convection over the surface of the mass. The Trombe Wall is an example of thermal mass storage that was originally designed as a passive system but has recently been incorporated in several hybrid systems that actively remove excess daytime thermal energy for storage in rock beds or use in remote rooms of the building. The Trombe Wall is basically a glass wall placed in front of a darkened concrete wall that has openings in the bottom to permit circulation of room air. The air is heated, rises, and reenters the room through openings at the top of concrete wall. The wall also radiates thermal energy to occupied spaces. Since 1956, when the first prototype using a Trombe Wall was constructed in France, its performance has been extensively documented. Forty percent of the building heating requirement can be supplied by solar energy when a passive Trombe Wall is used (20). Data Sheet 8 in Appendix A provides more information.

Another application of thermal mass storage can be seen in the use of brick and other masonry materials for floor surfaces. The floor collects, stores, and releases the solar energy that enters the windows during the day. The 
thermal lag of the materials decreases the auxiliary heating needed until the sleeping hours, when thermostat setback can take place.

The above storage methods are available today and have been found to be feasible as low-technology applications to assist home heating.

Other solids have been examined for use in sensible storage of thermal energy in much the same way as rock is used. These solids could be melted and processed into spheres of uniform size, or cast into grid shapes, to allow air to circulate and remove or add thermal energy. A small list of possibilities is shown in Table 1 . The table provides a comparison between various solids for energy storage.

TABLE 1. CANDIDATES FOR SENSIBLE STORAGE OF THERMAL ENERGY FROM $77^{\circ} \mathrm{F}$ TO $900^{\circ} \mathrm{F}$ (21)

\begin{tabular}{|c|c|c|c|c|c|}
\hline Material & $1 \mathrm{~b} / \mathrm{ft} \mathrm{t}^{3}$ & Btu/1b & $\underline{B t u} / \mathrm{ft}^{3+}$ & $\$ / 1001 \mathrm{~b} *$ & $\begin{array}{l}\text { Output } \\
\text { (Btu/S) } *^{+}\end{array}$ \\
\hline $\mathrm{Al}$ & 168 & 200 & 34,000 & 53.00 & 380 \\
\hline Steel & 489 & 99 & 48,300 & 20.00 & 490 \\
\hline $\mathrm{Al}_{2}\left(\mathrm{SO}_{4}\right)_{3}$ & 169 & 202 & 34,000 & 6.85 & 2,950 \\
\hline $\mathrm{Al}_{2} \mathrm{O}_{3}$ & 250 & 200 & 50,000 & 5.50 & 3,640 \\
\hline MgO & 223 & 208 & 46,000 & 6.00 & 3,470 \\
\hline $\mathrm{KCl}$ & 124 & 140 & 17,400 & 2.00 & 7,000 \\
\hline $\mathrm{K}_{2} \mathrm{SO}_{4}$ & 167 & 180 & 30,000 & .10 & 180,000 \\
\hline $\mathrm{NaCl}$ & 136 & 180 & 24,500 & 2.75 & 6,545 \\
\hline Rocks & 140 & 180 & 25,200 & .50 & 36,000 \\
\hline
\end{tabular}

The use of hollow steel ingots for storing high-temperature solar energy has also been modelled in the laboratory. It has yet to be tested in practical applications. 


\section{Phase-Change Materials}

Thermal energy storage using phase-change materials (PCMs) is an attractive alternative to sensible storage in rocks and water. Storage using PCMs exploits the well-known property of substances to absorb heat isothermally when undergoing a change of phase.

From the standpoint of the design of thermal energy storage equipment, phase-change materials have two primary advantages (and associated disadvantages) over sensible storage materials. First, the energy density is higher; the amount of thermal energy that can be stored in a given volume over the same temperature variation is greater. Water, for example, has a specific heat of $1 \mathrm{Btu} / \mathrm{lb}-{ }^{\circ} \mathrm{F}$. This means that one Btu is required to raise the temperature of one pound of water one degree Fahrenheit (effectively 1 Btu has been stored). To melt the same pound of water from its solid phase as ice to its liquid phase isothermally at $32^{\circ} \mathrm{F}$, requires $144 \mathrm{Btu}$ (effectively storing $144 \mathrm{Btu}$ ). When space is at a premium in a particular application and when large containers are cost prohibitive, PCMs have a distinct advantage over sensible storage materials.

Second, PCMs have the ability to store thermal energy over a narrower temperature range than do sensible storage materials. When integrated into a building structure, PCMs will act as temperature regulators, absorbing and releasing thermal energy at the phase-change temperature. An additional disadvantage of sensible systems occurs when the storage temperature gets close to the collector operating temperature resulting in a decrease in collection efficiency. By absorbing thermal energy isothermally, PCMs store thermal energy without lowering temperature differentials. In a heat pump application the coefficient of performance (COP) of a heat pump tends to decrease as the heat source temperature decreases. If the heat source is a sensible storage system, the COP tends to go down as the thermal energy is extracted from storage. Using a PCM storage allows the designer to optimize heat pump performance by using a single temperature for the heat source. Along with these advantages there is one disadvantage of PCM for thermal energy storage. Since each PCM has a characteristic temperature, a PCM must be identified for each temperature application and a system designed and built around its particular characteristics.

Researchers at the Institute of Gas Technology have devised the following general temperature range breakdown in order to describe potential storage applications more conveniently (22). 
Temperature Range

Application
40 to $60^{\circ} \mathrm{F}$
Cooling
60 to $200^{\circ} \mathrm{F}$
Heating and cooling
200 to $600^{\circ} \mathrm{F}$
Commercial/industrial applications
$600^{\circ} \mathrm{F}$ and above
Power generation and high-tempera- ture processing

Phase-change transformations may be classified as follows (23):

(1) Liquid-gas transformation

(2) Solid-gas transformation

(3) Solid-liquid transformation

(4) Solid-solid transformation.

Although the liquid-gas and solid-gas transformations do store large amounts of thermal energy, the large volume changes associated with them require complicated storage vessel designs. Because of this, not much emphasis has been placed on studying potential materials in those classes of thermal storage materials. Hence, this effort has involved the study of solid-liquid and solid-solid transformations, where the volume changes associated with the phase change are smaller.

\section{Solid-Liquid Transformation}

Considerable work has been done to identify potential phase-change materials at various temperatures. Researchers at Dow Chemical have identified over 200 substances which melt at temperatures from 50 to $194^{\circ} \mathrm{F}$ with characteristics worthy of laboratory evaluation (24). A recent compilation by the National Bureau of Standards provides a compendium of melting points and compositions of 6,000 molten salt eutectic mixtures which melt in the range of -216 to $3072^{\circ} \mathrm{F}$ (25). Researchers at General Electric have identified 81 potential PCMs for storage in the 40 to $60^{\circ} \mathrm{F}$ range (26).

In the late forties, $\mathrm{Dr}$. Maria Telkes constructed and designed a thermal energy storage unit for a solar house using sodium sulfate decahydrate as the phase-change material (27). More recently $\mathrm{Dr}$. Telkes has been responsible for the 
development of the thermal energy storage system on "Solar One," a solar test house built at the University of Delaware (28).

The Solar One system, shown in Figure 12, combined heating and cooling capacity storage using two phase-change materials. Heating capacity storage was provided by 294 plastic $21 \times 21 \times 1$-in rectangular trays. Each pan contained 23.8 Ibs of sodium thiosulfate pentahydrate $\left(\mathrm{Na}_{2} \mathrm{~S}_{2} \mathrm{O}_{3}\right.$. $\left.5 \mathrm{H}_{2} \mathrm{O}\right)$ with a melting point of $120^{\circ} \mathrm{F}$ and a heat of fusion of $90 \mathrm{Btu} / \mathrm{Ib}$. The trays were constructed with plastic separators to allow air to flow freely through the bin. Cooling capacity storage was provided by an eutectic salt mixture of sodium sulfate decahydrate, sodium chloride, and ammonium chloride $\left(\mathrm{Na}_{2} \mathrm{SO}_{4} \cdot 10 \mathrm{H}_{2} \mathrm{O} / \mathrm{NaCl} / \mathrm{NH}_{4} \mathrm{Cl}\right.$ ) melting at $55^{\circ} \mathrm{F}$ with a heat of fusion of $78 \mathrm{Btu} / \mathrm{Ib}$. The eutectic salt was contained in twenty 1.25-in (outside diameter) by 72-in tubes, each containing 4.02 Ibs of the mixture. The tubes were stacked using plastic separators so air could flow freely through the bin. The two storage arrays were integrated into a single $6 \times 6 \times 6$-ft container. With a rise in temperature of 70 to $126^{\circ} \mathrm{F}$, the total thermal energy stored in the bin was $807,000 \mathrm{Btu}$. The total cooling capacity stored or the thermal energy that the unit would absorb when the temperature rose from 50 to $75^{\circ} \mathrm{F}$ was 242,000 Btu. See Data Sheets 17 and 18 in Appendix $A$ for specific information.

Researchers at the University of Pennsylvania have designed and constructed two thermal energy storage systems using PCMs (29). The first system melted sodium thiosulfate pentahydrate $\left(\mathrm{Na}_{2} \mathrm{~S}_{2} \mathrm{O}_{3} \cdot 5 \mathrm{H}_{2} \mathrm{O}\right.$ ) at $119^{\circ} \mathrm{F}$ with a heat of fusion of $90 \mathrm{Btu} / 1 \mathrm{~b}$. The PCM was placed in a $1 \times 1 \times 4-\mathrm{ft}$ plastic module. The total system contained a stack of sixteen modules. The thermal energy storage capacity of the unit was 500,000 Btu in 64 cubic feet using 5,560 lbs of sodium thiosulfate pentahydrate. The heat transfer was accomplished by circulating a water and ethylene glycol mixture through the center of the module. See Data Sheet 19 in Appendix A for additional details and system parameters.

The second thermal energy storage unit in the University of Pennsylvania study melted Sunoco 116 paraffin wax at $116^{\circ} \mathrm{F}$ with a heat of fusion of $90 \mathrm{Btu} / 1 \mathrm{~b}\left(4400 \mathrm{Btu} / \mathrm{ft}^{3}\right)$. The paraffin was placed in $0.54 \times 12 \times 50$-in trays. These trays were stacked in $12 \times 12 \times 50$-in modules using plastic spacers to allow circulation of the heat transfer fluid. A 250,000-Btu unit was made up of twenty such modules initiating up to $83 \mathrm{ft}^{2}$. The unit contained 2,000 lbs of 116 paraffin (see Data Sheet 20 for additional details).

Researchers at the Dayton Laboratory of the Monsanto Research Corporation have developed a form-stable crys- 


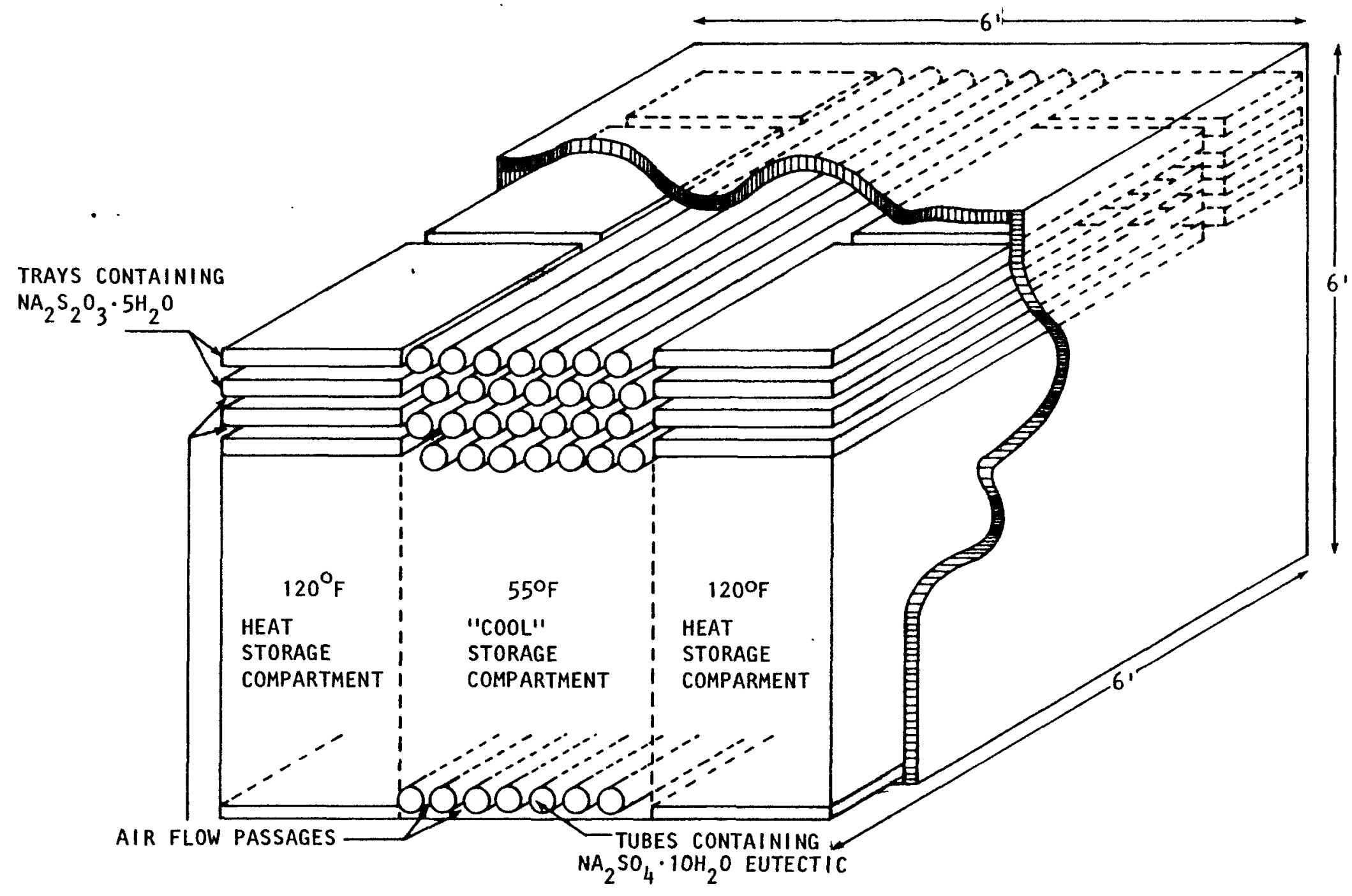

Figure 12. Solid Cross Section of Solar One Thermal Storage Bin 
talline polymer-pellet thermal storage material with a high heat of fusion ( $83 \mathrm{Btu} / \mathrm{lb}$ ) at a melting temperature of $266^{\circ} \mathrm{F}$ (36). The polyethylene pellets were rendered form-stable upon melting through cross-linking, allowing them to be used as a pellet bed for fluid or for air direct-flow heat transfer. Samples of the pellets have been put through 400 melt/freeze cycles with little degradation of their initial heat of fusion value, excellent retention of their formstability characteristics, and little or no interparticle adhesion. A 60-gal pressurized storage system using 250 1bs of the PCM and storing 29,400 Btu was constructed and tested. Results indicated that a thermal storage system based on this concept would be practical. It was determined that a 0.25 in-diameter pellet provided no heat transfer problems. Additional information is provided in Data sheet 13 .

Solarmatic, Inc., a division of OEM Products, is currently marketing a heat storage unit called a "Heat Battery." A 6-ft cylinder, with a 3-ft diameter, stores 340,000 Btu using Glauber's salt as the phase-change material. This unit is also compatible with hypo as the phase-change material. The tank (see Figure 13) is filled with Glauber's salt up to the 4-1/2-ft level. A floating filter interface a few inches thick is then poured on the salt. The remainder of the tank is filled with a low-viscosity oil. A coil of copper tubing inserted into the oil layer is used as a heat exchanger. A novel pump feed pipe has been devised to circulate heat in the tank. The hot oil is bubbled through the pipes up through the salt until it rises back to the oil level. The heat transfer media, oil, is in direct contact with salt during the bubbling process. For more details refer to Data Sheet 9 in Appendix A.

Valmont Industries, in a joint venture with the American Technological University in Texas, is planning to market by a thermal storage component using an encrusted conglomerate of Glauber's salt as the phase-change material by late 1978 (30). The encrusted conglomerate consists of 97 percent Glauber's salt and 3 percent additives. This mixture, developed by $\mathrm{Dr}$. Maria Telkes, stores $100 \mathrm{Btu} / 1 \mathrm{~b}$ at $89^{\circ} \mathrm{F}$ in a phase-change transformation. The additives create a honeycomb structure of closed cells locking the Glauber's salt crystal into a rigid latticework (see Figure 14). These cells remain rigid as the Glauber's salt is alternately melted and solidified. It is claimed that this solves many of the problems associated with the segregration by gravity of the eutectic mixture when in the 1iquid phase. The conglomerate will be packaged in high-impact polyethylene trays containing 20 lbs of the mixture. Refer to Data Sheet 10 in Appendix $A$. 


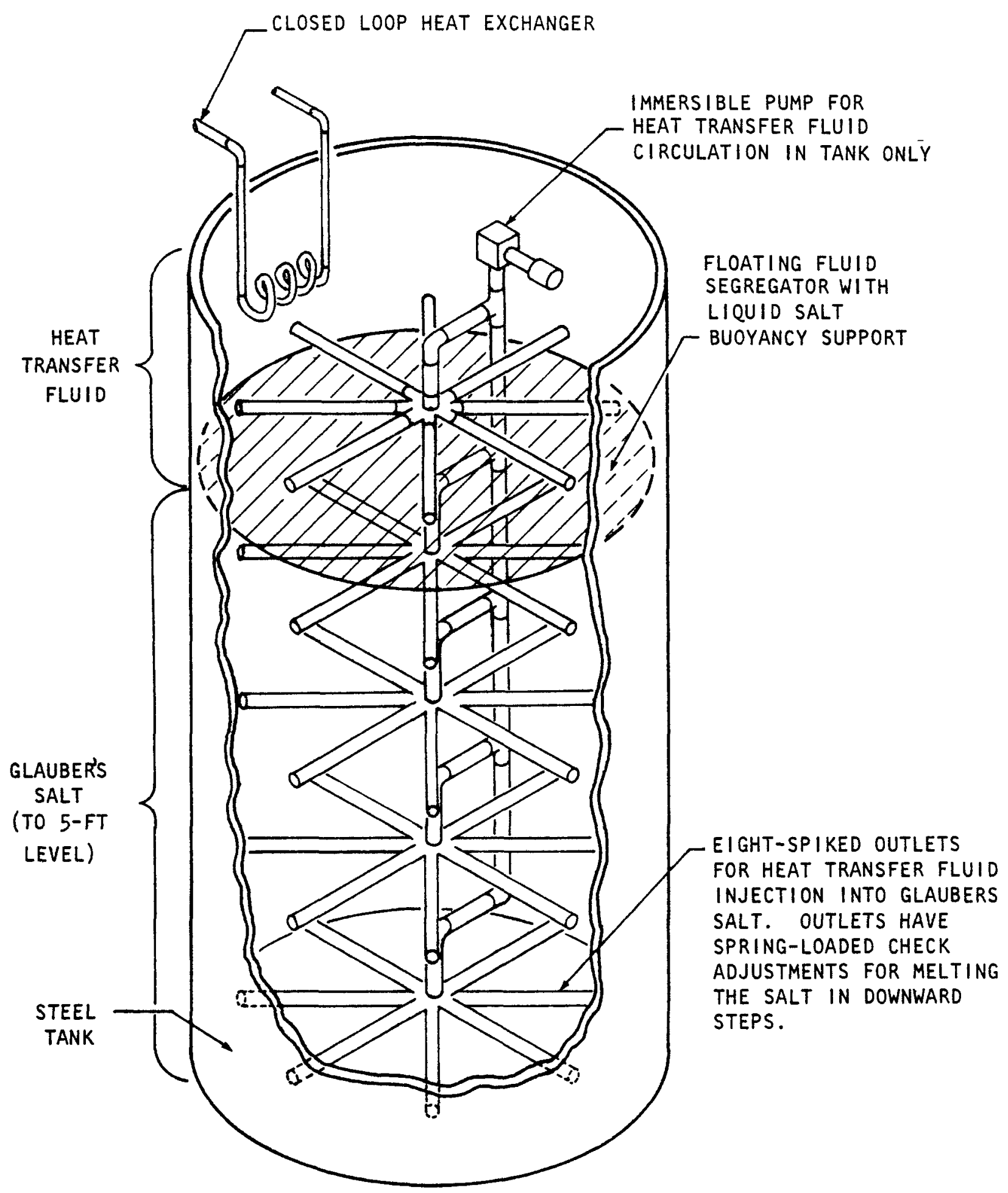

Figure 13. Solarmatic Heat Battery 


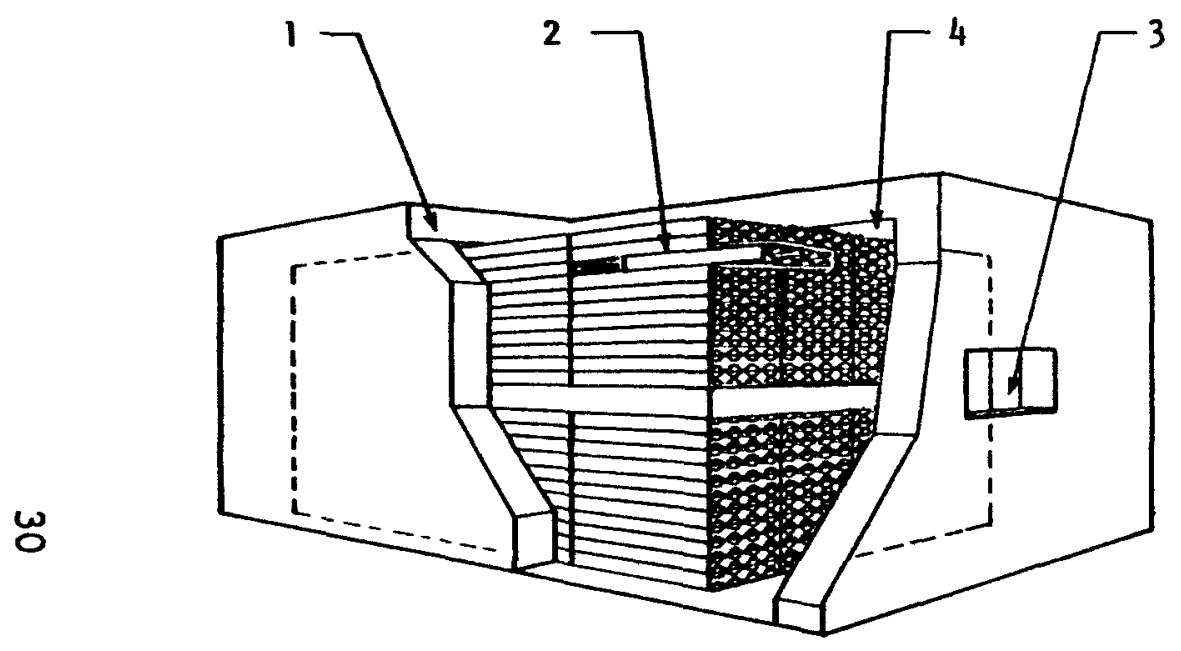

A. STORAGE GONCEPT

1. InSUlated StORAGE CABINET

2. EUTECTIC SALT STORAGE CONTAINERS

3. AIR DUCT CONNECTION

4. AIR CHAMBER WITH ACCESS

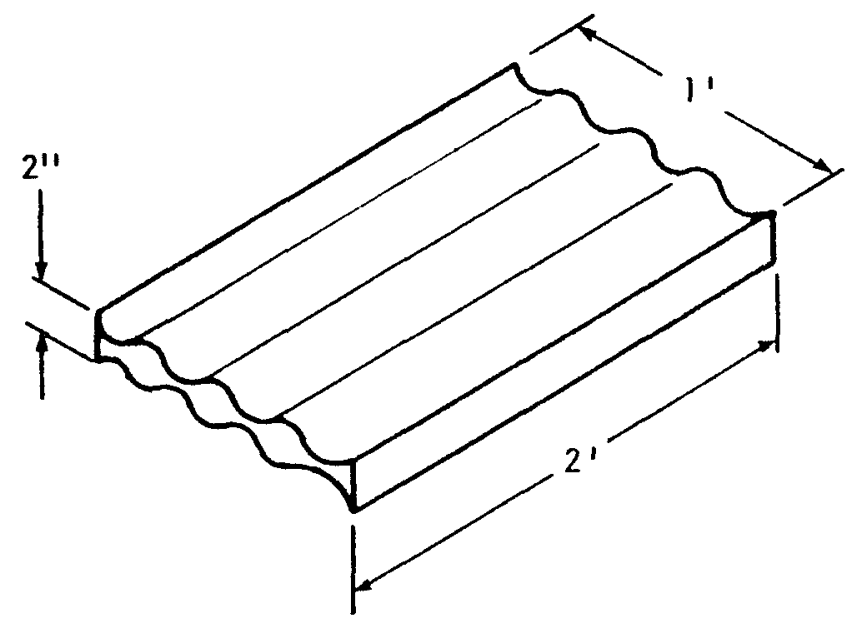

B. CONTAINER TRAY 20lbs. EACH

Figure 14. Encrusted Conglomerate Valmont Storage Unit 
Solar Marketing Corporation in Nebraska is planning to make available a storage product they call SMC Thermal Storage Cells by the end of 1978 (31). The phase-change material is Glauber's salt melting at $90^{\circ} \mathrm{F}$, storing 91 $\mathrm{Btu} / \mathrm{lb}$ as heat of fusion. The cells will be sold as units containing 3.85 lbs of the eutectic mixture enclosed in high-density polyethylene. The cells are designed to be charged and discharged using hot-air heat transfer. Refer to Data Sheet 11 in Appendix A for system parameters.

Architectural Research Corporation is currently marketing a ceiling tile, shown in Figure 15, which uses a eutectic mixture with Glauber's salt as the active material with the phase-change at $73^{\circ} \mathrm{F}$. The tiles, which are $24 \times 24$ x 1-1/4-in and weigh 44 lbs, store 880 Btu per tile over a range of $10^{\circ} \mathrm{F}\left(68\right.$ to $\left.78^{\circ} \mathrm{F}\right)$. The tile is a sandwich of 24 lbs of the eutectic contained in two plastic bags, each $3 / 8-$ in thick. Twenty pounds of polyester concrete surround the eutectic. The system is now designed to be used as a passive building element to be charged by direct (or reflected) insolation or to absorb and store "waste" thermal energy from bodies and appliances $(32,33)$. Refer to Data Sheet 12 in Appendix A.

Researchers at the General Electric Research and Development Center are developing a thermal energy storage unit using Glauber's salt as the PCM. A cylindrical drum, shown in Figure 16, is 95-percent filled with Glauber's salt and rotated along its axis at $3 \mathrm{rpm}$ by a small motor (34). During thermal energy extraction, this slow rotation provides enough agitation to keep the salt temperature uniform and prevent the salt from solidifying on the wall of the container and slowing down the heat transfer process. A recent technical publication by General Electric Company's Research and Development Division lists the following experimental results (35):

(a) One hundred percent crystallization of $\mathrm{Na}_{2} \mathrm{SO}_{4} \cdot 10 \mathrm{H}_{2} \mathrm{O}$.

(b) Repeatable freeze-thaw cycling without degradation after 150 cycles.

(c) Satisfactory repeatable nucleation.

(d) High heat transfer rates -- solids do not adhere to the heat transfer surface.

(e) High volumetric efficiency. 


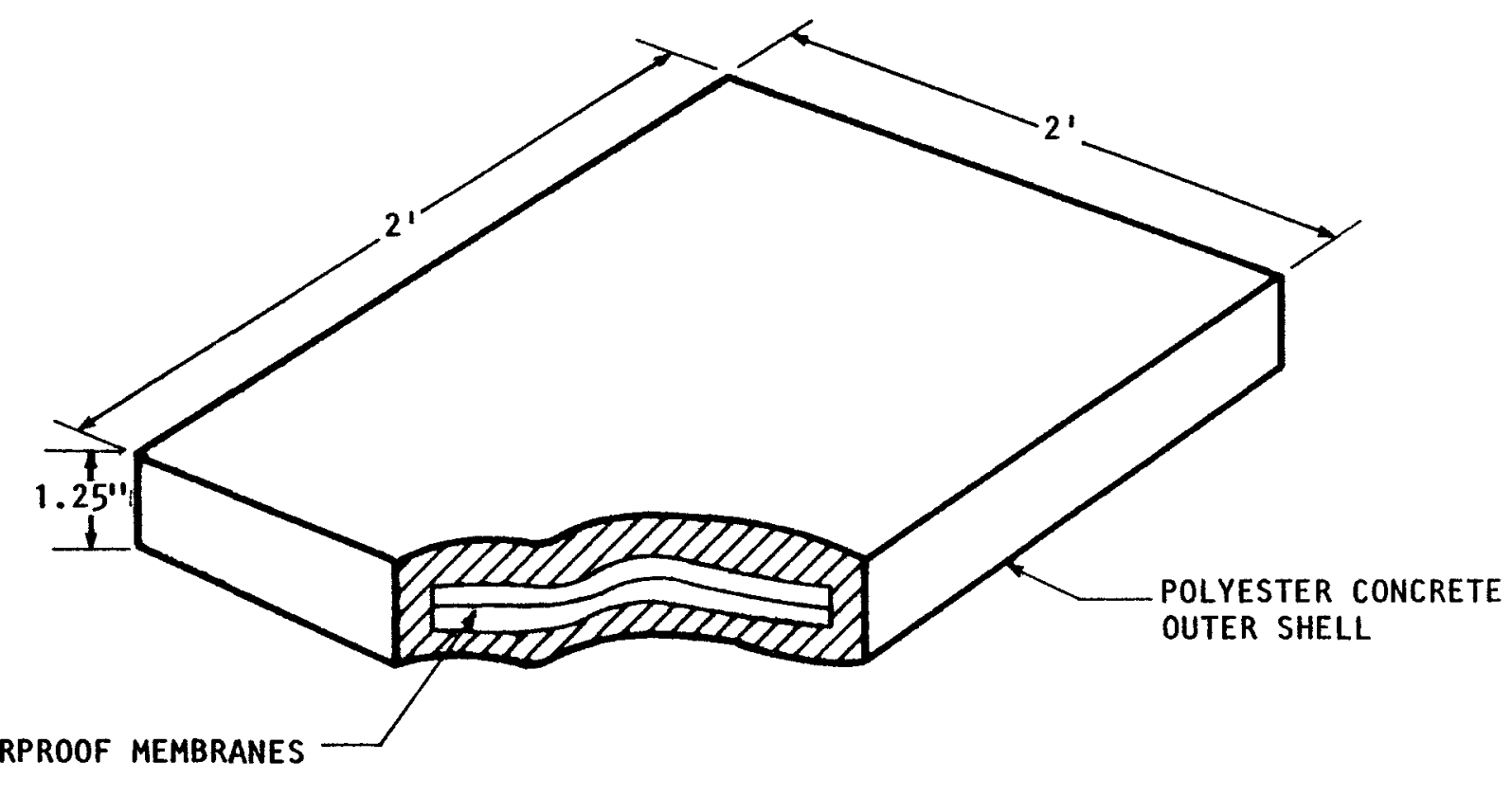

3/8" EACH 


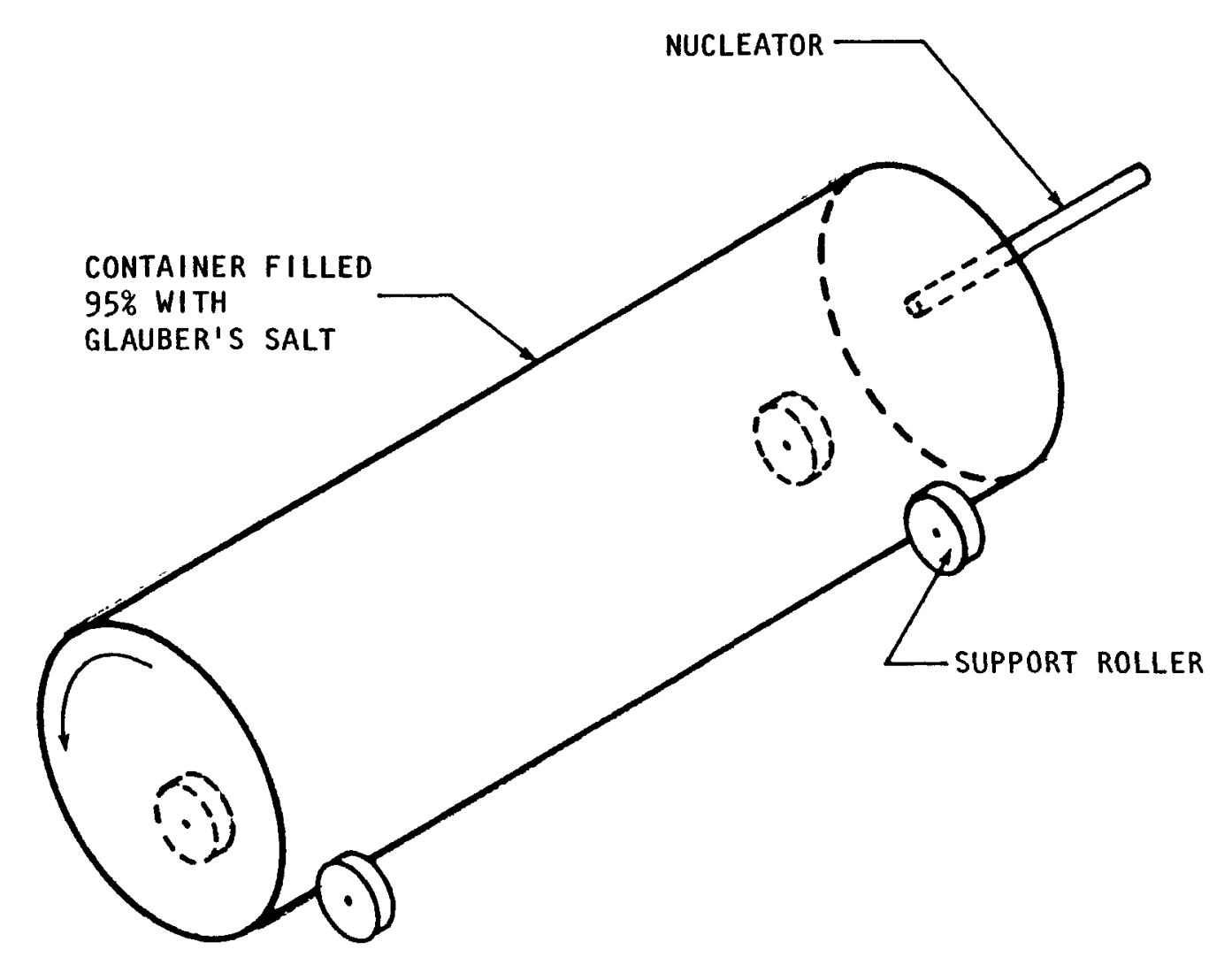

SOURCE: GENERAL ELECTRIC

Figure 16. Rolling Cylinder Thermal Energy Storage Unit 
(f) Melt-thaw volume change is not a problem.

(g) Corrosion in the metal-walled vessel has been controlled by additives without affecting the crystallization behavior.

(h) Noise levels have been low. No noise problem is evident.

A storage system built on this concept would require an 850gallon cylinder filled to 94 percent capacity with Glauber's salt to store $1 \times 106 \mathrm{Btu}$. GE is now involved in a project to design, build, and test a prototype system using the rolling cylinder with a capacity of approximately 200,000 Btu. Refer to Data Sheet 21 for additional details.

The Addison Products Company of Addison, Michigan, is currently marketing a thermal energy storage unit using a "slack wax" as the PCM $(37,38)$. The wax changes phase at about $115^{\circ} \mathrm{F}$. The wax is sealed in standard one-gallon metal cans. These cans are stacked twenty to a shelf with seven shelves per storage chamber. The chamber enclosure is a $6 \mathrm{x}$ $6 \times 3-\mathrm{ft}$ bin with 4 inches of polystyrene for insulation in the walls. Hot air enters at the top and flow through each shelf in succession, exiting through the bottom of the opposite side (see Figure 17). Storage capacity of the chamber is about 125,000 Btu. See Data Sheet 14 in Appendix A for additional details.

The Annual Cycle Energy System (ACES) is a residential and commercial heating and air-conditioning system that also provides domestic water heating. Water is frozen during the winter season and the stored ice provides "free" air-conditioning during the summer (39). The major elements of an ACES are:

(a) A high efficiency heat pump with refrigerant-tobrine heat exchangers on both the evaporating and condensing sides.

(b) An ice storage tank to store ice.

(c) Ice building coils to make ice.

(d) A forced-air circulating system with a fan coil for space heating and cooling.

(e) A tank for storing domestic hot water. 


\section{TOP VIEW CROSS SECTION}

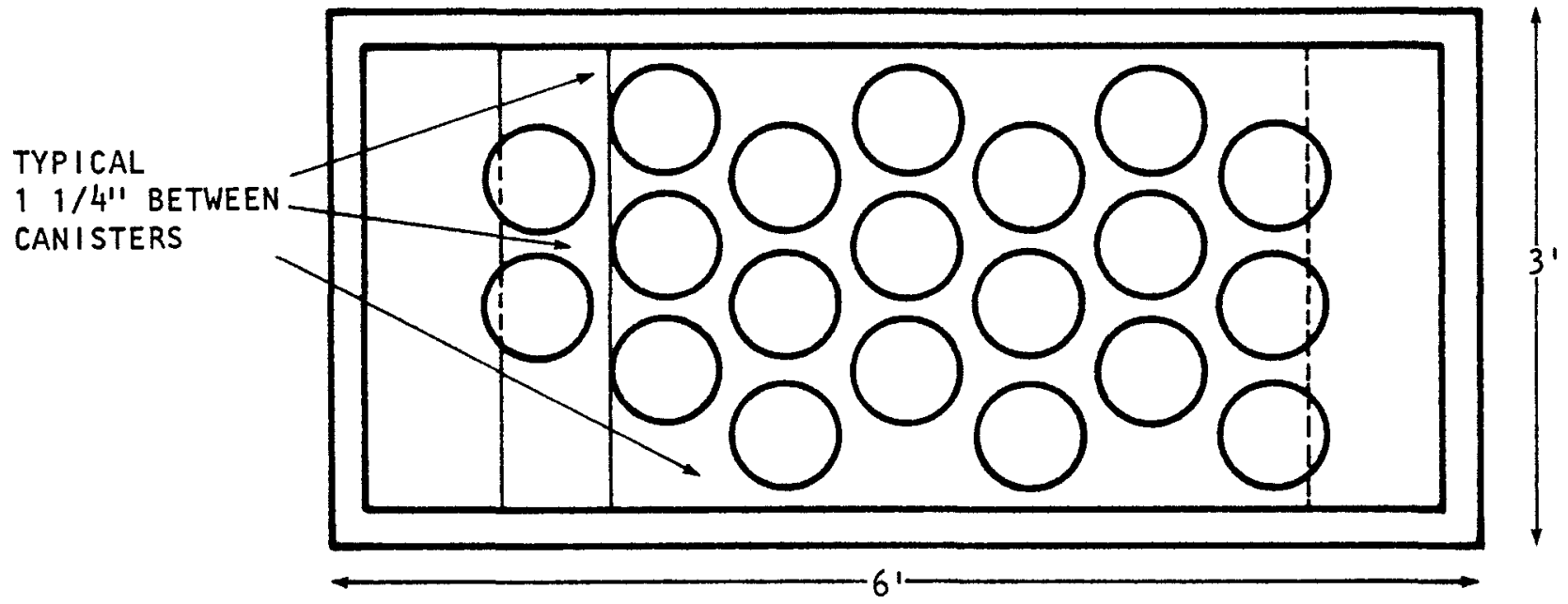

SIDE VIEW CROSS SECTION

HEATED

AIR FROM

COLLECTORS

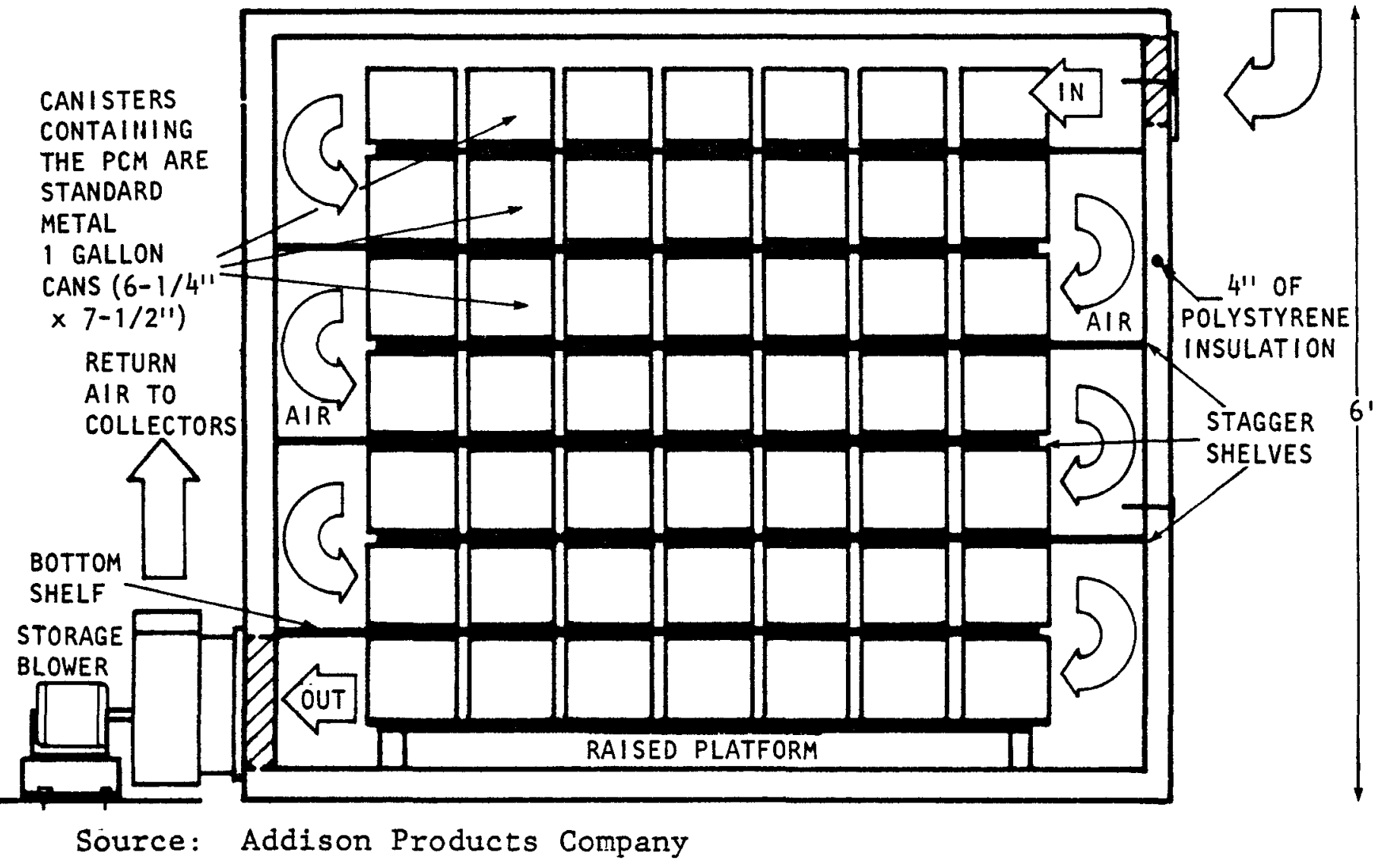

Figure 17. Add-A-Sun Storage Chamber 
(f) A refrigerant-to-water heat exchanger.

The ACES is shown schematically in Figure 18. Space heating is accomplished by circulating brine from the heating condenser through the fan coil and transferring the heat to the living space by the circulating air system. Space cooling is accomplished by circulating brine from the ice storage tank through a fan coil unit to lower the temperature of circulating air distributed to space. The selector valves choose the brine circuit for heating or cooling as required. The domestic water is heated by recirculation through the hot-water condenser.

The criteria used for selecting the ice bin size vary. In climates where the heating load considerably exceeds the cooling load the ice bin is sized to store adequate ice for the cooling season but is not large enough to provide full heating requirements. The deficiency of available heat from the ice bin is made up by the radiant/convector panel. In climates where the cooling load exceeds the heating load, the ice bin is sized based on the heating load. If the ice is exhausted before the end of the cooling season, the compressor will be permitted to operate at night when the air temperature falls below a predetermined temperature of about $80^{\circ}$ to chill the water and perhaps make ice.

The demonstration house is a $2,000 \mathrm{ft}^{2}$ single family housing unit with an ice inventory of $2,000 \mathrm{ft}^{3}$. The c001ing and heating capacities of the system is $25,000 \mathrm{Btu} / \mathrm{hr}$ at $25^{\circ} \mathrm{F}$ brine outlet and $30,000 \mathrm{Btu} / \mathrm{hr}$ at $105^{\circ} \mathrm{F}$ condensing. See Data Sheet 15 for additional information.

\section{Solid-Solid Transformation}

Calmac Manufacturing Corporation, under a grant from NASA, has developed a PCM storage unit using sodium sulfate (Na2SO4) for high-temperature storage (41). The sodium sulfate was formed, using a proprietary process developed by Calmac, into compressed pebbles hard enough to use as a pebble bed. The unit, shown in Figure 19, stores thermal energy over a range of 400 to $600^{\circ} \mathrm{F}$. The phase change is a solid-to-solid transition which occurs at $465^{\circ} \mathrm{F}$. The thermal energy storage principle is a combination of sensible heat storage of solid and the latent heat storage of the phase changing. Although a liquid (Therminol-X) was used as the heat-transfer fluid (being circulated through the tank over the pebble bed), use of an air-heat transfer system is possible. Pebbies of prepared sodium sulfate are commercially available from Calmac in industrial lots. For construction and unit performance parameters, refer to Data Sheet 16 in Appendix A. 


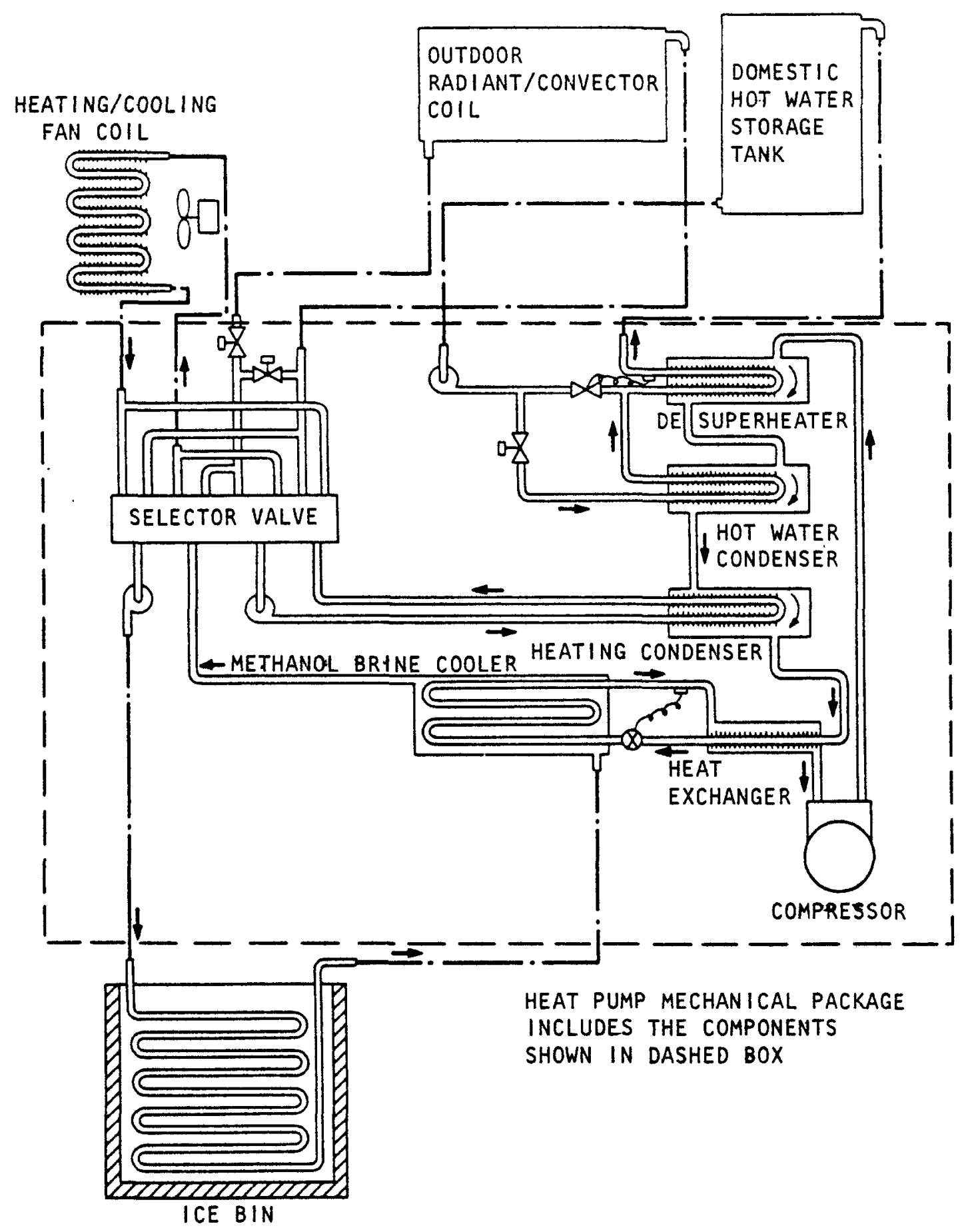

Figure 18. System Schematic (ACES) 


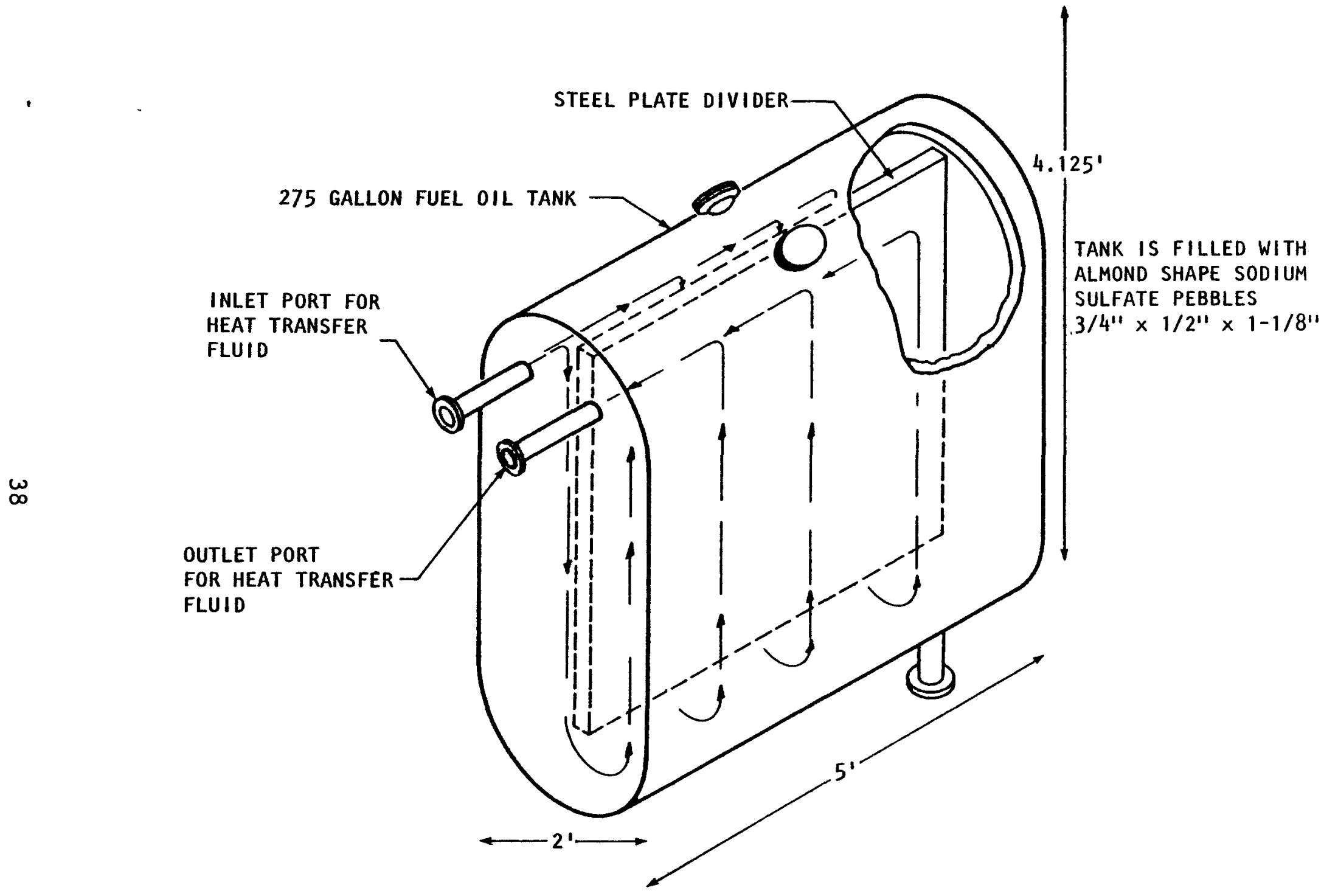

Figure 19. Calmac's Sodium Sulfate Storage Tank 


\section{Thermochemical Energy Storage}

\section{Introduction}

Energy storage using the principle of reversible chemical reactions is thermochemical energy storage (TCES). The primary interests in thermochemical energy storage technology have been in solar thermal electric power plant and nuclear power plant applications $(42,43,44,45)$. Chemical heat pipes using thermochemical technology are of considerable interest in energy transmission and distribution for coal gasification plants (open loop heat pipe), high-temperature nuclear reactor (high-temperature heat pipe), and moderate temperature source applications including nuclear, solar and fossil energies (low-temperature heat pipe) (42). Chemical heat pump storage with its reversible chemical reaction is also attractive in solar heating and cooling for buildings. TCES offers several basic advantages.

(a) Chemicals can be stored separately under atmospheric conditions and the storage time can be extended indefinitely without using insulation.

(b) Energy density (energy content per unit mass) for TCES is relatively high.

(c) TCES can be used as a heat pump.

\section{Storage Principle}

The basic principle of TCES can be described by the following example. A chemical compound, $A B$, decomposes into reactants $A$ and $B$ at a higher temperature level. The chemical reaction:

$$
\mathrm{AB} \rightarrow \mathrm{A}+\mathrm{B}
$$

is endothermic where energy is stored into the chemical reactants $A$ and $B$. The reactants $A$ and $B$ can be stored separately and then recombined at a later time. The chemical reaction:

$$
A+B \rightarrow A B
$$

is exothermic where the stored energy is released at a lower temperature level. For effective application of TCES the reversible chemical reaction: 
selected should have controllable chemical reactions at the desired temperature range. The reactants $A$ and $B$ should be easily separable immediately after decomposition to avoid recombination. The candidate reactions are listed in Tables 2 and 3 .

\section{Discussion}

The storage of thermal energy in reversible chemical reactions is a relatively new field. The technology is just beginning to be explored, and only limited information is available.

Some of the work being done on TCES is listed in Table 4 (47). Most of the TCES reactions require operating temperatures above $300^{\circ} \mathrm{C}$. Only sulfuric acid systems are in the temperature range of 90 to $150^{\circ} \mathrm{C}$. A selected sufuric acidwater system will be discussed in Section 4 of this chapter.

Chemical heat pumps (CHP) are of considerable interest. A chemical heat pump has the advantage of a reversible thermal chemical reaction but does not require any moving parts to operate. A CHP is driven by the pressure difference generated between two interconnected chemical reactors. Using a heat pump analogy, reactor $A$ is an evaporator where a chemical compound is decomposed and energy is added either by solar or by other means. The vapor pressure of decomposed gaseous reactant will drive the gaseous reactant itself through the passage to the reactor $B$ where a lower temperature will be maintained. Reactor $B$ is a condenser where the gaseous reactant is condensed to liquid. The energy released due to condensation is removed either by air or by water depending on the available source. The charge cycle is then complete and the energy is stored in reactor B. During the discharge cycle, the chemical reaction is reversed. When the temperature of reactor A drops, the vapor pressure of the gaseous reactant in reactor $A$ will be lower than that of reactor $B$. The gaseous reactant will flow from reactor $B$ through the passage to reactor $A$ where the chemical compound is formed and energy is released. This energy could be a source for space heating. At reactor $B$, however, gaseous reactant evaporates and energy is drawn from a space where cooling may be needed.

The potential candidate reactions for CHP are many. Inorganic salt substrate with methanol gas $\left(\mathrm{CH}_{3} \mathrm{OH}\right)$, water vapor absorption with magnesium chloride dihydrate $\left(\mathrm{MgCl}_{2} \cdot 2 \mathrm{H}_{2} \mathrm{O}\right)$,
sulfuric acid with water dilution, and paired ammoniated 


\section{TABLE 2. ENERGY CONTENT OF CANDIDATE CHEMICAL ENERGY STORAGE REACTIONS, SYSTEMS EXCLUDING \\ SOLID CONSTITUENTS (45)}

\begin{tabular}{|c|c|c|c|c|}
\hline \multirow{2}{*}{ - $\quad \begin{array}{c}\text { Reaction } \\
\text { exothermic }\end{array}$} & \multicolumn{2}{|c|}{$\begin{array}{l}\text { Reaction Enthalpy } \\
\text { at } 298^{\circ} \mathrm{K}\left(77^{\circ} \mathrm{F}\right)\end{array}$} & \multicolumn{2}{|c|}{ Temperature $\left({ }^{\circ} \mathrm{K}\right)$ at which } \\
\hline & $W_{s / g}{ }^{a}$ & Btu/lb & $90 \%$ Formed & $90 \%$ Dissociated \\
\hline $\mathrm{CO}(\mathrm{G})+3 \mathrm{H}_{2}(\mathrm{G}) \rightleftharpoons \mathrm{CH}_{4}(\mathrm{G})+\mathrm{H}_{2} \mathrm{O}(\mathrm{L})$ & 7,345 & 3,160 & - & _ \\
\hline $\mathrm{CO}(\mathrm{G})+3 \mathrm{H}_{2}(\mathrm{G}) \rightleftharpoons \mathrm{CH}_{4}(\mathrm{G})+\mathrm{H}_{2} \mathrm{O}(\mathrm{G})$ & 6,053 & 2,604 & 754 & 1,466 \\
\hline $\mathrm{C}_{2} \mathrm{H}_{4}(\mathrm{G})+\mathrm{H}_{2}(\mathrm{G}) \rightleftharpoons \mathrm{C}_{2} \mathrm{H}_{6}(\mathrm{G})$ & 4,561 & 1,962 & 841 & 1,205 \\
\hline $2 \mathrm{CO}(\mathrm{G})+2 \mathrm{H}_{2}(\mathrm{G}) \rightleftharpoons \mathrm{CH}_{4}(\mathrm{G})+\mathrm{CO}_{2}(\mathrm{G})$ & 4,118 & 1,772 & 778 & 1,152 \\
\hline $\mathrm{CO}(\mathrm{G})+2 \mathrm{H}_{2}(\mathrm{G}) \rightleftharpoons \mathrm{CH}_{3} \mathrm{OH}(\mathrm{L})$ & 3,996 & 1.718 & 345 & 434 \\
\hline $\mathrm{N}_{2}(\mathrm{G})+3 \mathrm{H}_{2}(\mathrm{G}) \rightleftharpoons 2 \mathrm{NH}_{3}(\mathrm{~L})$ & 3,861 & 1,661 & - & - \\
\hline $\mathrm{N}_{2}(\mathrm{G})+3 \mathrm{H}_{2}(\mathrm{G}) \rightleftharpoons 2 \mathrm{NH}_{3}(\mathrm{G})$ & 2,695 & 1,159 & 346 & 528 \\
\hline $2 \mathrm{NO}(\mathrm{G})+\mathrm{O}_{2}(\mathrm{G}) \rightleftharpoons \mathrm{N}_{2} \mathrm{O}_{4}(\mathrm{~L})$ & 1,750 & 753 & 549 & 930 \\
\hline $\mathrm{SO}_{2}(\mathrm{G})+\mathrm{Air} \rightleftharpoons \mathrm{SO}_{3}(\mathrm{G})$ & 1,544 & 644 & 806 & 1,270 \\
\hline $\mathrm{SO}_{2}(\mathrm{~L})+1 / 2 \mathrm{O}_{2}(\mathrm{G}) \rightleftharpoons \mathrm{SO}_{3}(\mathrm{~L})$ & 1,517 & 652 & 792 & 1,235 \\
\hline $\mathrm{SO}_{2}(\mathrm{G})+1 / 2 \mathrm{O}_{2}(\mathrm{G}) \rightleftharpoons \mathrm{SO}_{3}(\mathrm{G})$ & 1,235 & 531 & 792 & 1,235 \\
\hline $\mathrm{NO}(\mathrm{G})+1 / 2 \mathrm{O}_{2}(\mathrm{G}) \rightleftharpoons \mathrm{NO}_{2}(\mathrm{G})$ & 1,243 & 535 & 549 & 930 \\
\hline $\mathrm{CO}(\mathrm{G})+\mathrm{Cl}_{2}(\mathrm{~L}) \rightleftharpoons \mathrm{CO} \mathrm{Cl}_{2}(\mathrm{~L})$ & 1172 & 504 & 628 & 881 \\
\hline $\mathrm{NO}_{2}(\mathrm{G})+\mathrm{NO}_{2}(\mathrm{G}) \rightleftharpoons \mathrm{N}_{2} \mathrm{O}_{4}(\mathrm{~L})$ & 932 & 401 & 288 & 381 \\
\hline $\mathrm{SO}_{3}(\mathrm{~L})+\mathrm{H}_{2} \mathrm{O}(\mathrm{L}) \rightleftharpoons \mathrm{H}_{2} \mathrm{SO}_{4}(\mathrm{~L})$ & 885 & 381 & 535 & 723 \\
\hline $\mathrm{SO}_{2}(\mathrm{G})+\mathrm{Air} \underset{\rightleftharpoons}{\rightleftharpoons} \mathrm{SO}_{3}(\mathrm{G})$ & 727 & 313 & 806 & 1,270 \\
\hline $\mathrm{NO}(\mathrm{G})+1 / 2 \mathrm{Cl}_{2}(\mathrm{~L}) \rightleftharpoons \mathrm{NOCl}(\mathrm{L})$ & 695 & 299 & 425 & 819 \\
\hline $\mathrm{H}_{2} \mathrm{O}(\mathrm{L})+\mathrm{H}_{2} \mathrm{SO}_{4}(\mathrm{~L}) \rightleftharpoons \mathrm{H}_{2} \mathrm{SO}_{4} \cdot \mathrm{H}_{2} \mathrm{O}(\mathrm{L})$ & 230 & 99 & - & - \\
\hline For comparison: & & & & \\
\hline $\mathrm{H}_{2}(\mathrm{G})+1 / 2 \mathrm{O}_{2}(\mathrm{G}) \rightleftharpoons \mathrm{H}_{2} \mathrm{O}(\mathrm{G})$ & 13,423 & 5,775 & 2,830 & 5,600 \\
\hline
\end{tabular}

* Based on $\mathrm{SO}_{2}$ weight only. Air open cycle.

$a_{W s / g}$ represents watt-second per gram. One Ws/g is equivalent to $2,326 \mathrm{Btu} / 1 \mathrm{~b}$. 
TABLE 3. ENERGY CONTENT OF CANDIDATE CHEMICAL ENERGY STORAGE REACTIONS, SYSTEMS WITH SOLID CONSTITUENTS (46)

\begin{tabular}{|c|c|c|c|c|c|}
\hline \multirow{2}{*}{$\begin{array}{c}\begin{array}{c}\text { Reaction } \\
\text { exothermic }\end{array} \\
\text { endothermic }\end{array}$} & \multicolumn{2}{|c|}{$\begin{array}{l}\text { Reaction Enthalpy } \\
\text { at } 298^{\circ} \mathrm{K}\left(77^{\circ} \mathrm{F}\right)\end{array}$} & \multicolumn{3}{|c|}{ Temperature at which $P_{\text {Diss. }}=$} \\
\hline & $W_{s / g}{ }^{a}$ & Btu/lb & $0.1 \mathrm{bar}^{b}$ & l bar & PCond. \\
\hline $\mathrm{Li}(\mathrm{S})+1 / 2 \mathrm{H}_{2}(\mathrm{G}) \rightleftharpoons \mathrm{LiH}(\mathrm{S})$ & 11,403 & 4,906 & 1,181 & 1,223 & - \\
\hline $\mathrm{NaF}(S)+(H F)_{n}(L) \rightleftharpoons \mathrm{Na} \mathrm{HF}_{2}(\mathrm{~S})$ & 4,442 & 1,911 & & & \\
\hline $\mathrm{Li}_{2} \mathrm{O}(\mathrm{S})+\mathrm{CO}_{2}(\mathrm{G}) \rightleftharpoons \mathrm{Li}_{2} \mathrm{CO}_{3}(\mathrm{~S})$ & 3,029 & 1.303 & & & \\
\hline $\mathrm{Na}_{2} \mathrm{O}(\mathrm{S})+\mathrm{CO}_{2}(\mathrm{G}) \rightleftharpoons \mathrm{Na}_{2} \mathrm{CO}_{3}(\mathrm{~S})$ & 3,014 & 1,296 & & 2,445 & \\
\hline $\mathrm{Mg}_{\mathrm{B}}(\mathrm{S})+\mathrm{H}_{2}(\mathrm{G}) \rightleftharpoons \mathrm{Mg} \mathrm{H}_{2}(\mathrm{~S})$ & 2,893 & 1,245 & $\sim 500$ & 560 & - \\
\hline $\mathrm{C}_{2} \mathrm{O}(\mathrm{S})+\mathrm{SO}_{3}(\mathrm{~L}) \rightleftharpoons \mathrm{Ca} \mathrm{SO}_{4}(\mathrm{~S})$ & 2,539 & 1,092 & & & \\
\hline $\mathrm{CaO}(\mathrm{S})+\mathrm{CO}_{2}(\mathrm{G}) \rightleftharpoons \mathrm{CaCO}(\mathrm{S})$ & 1,776 & 764 & 1,028 & 1,171 & \\
\hline $\mathrm{MgO}(\mathrm{S})+\mathrm{CO}_{2}(\mathrm{G}) \rightleftharpoons \mathrm{Mg} \mathrm{CO}_{3}(\mathrm{~S})$ & 1,387 & 597 & & 670 & \\
\hline $\mathrm{BaO}(\mathrm{S})+\mathrm{CO}_{2}(\mathrm{G}) \rightleftharpoons \mathrm{BaCO}_{3}(\mathrm{~S})$ & 1,353 & 582 & & 1,473 & \\
\hline $\mathrm{NiCl}_{2}(\mathrm{~S})+6 \mathrm{NH}_{3}(\mathrm{~L}) \rightleftharpoons\left[\mathrm{Ni}\left(\mathrm{NH}_{3}\right)_{6}\right] \mathrm{Cl}_{2}(\mathrm{~S})$ & 1,301 & 560 & & & \\
\hline $\mathrm{NH}_{3}(\mathrm{~L})+\mathrm{H}_{2} \mathrm{SO}_{4}(\mathrm{~L}) \rightleftharpoons \mathrm{NH}_{4} \mathrm{HSO}_{4}(\mathrm{~S})$ & 1,256 & $\$ 40$ & - & - & - \\
\hline$K F(S)+(H F)_{n}(L) \rightleftharpoons K H F_{2}(S)$ & 1,031 & 444 & & & \\
\hline $\mathrm{CaO}(\mathrm{S})+\mathrm{H}_{2} \mathrm{O}(\mathrm{L}) \rightleftharpoons \mathrm{Ca}(\mathrm{OH})_{2}(\mathrm{~S})$ & 880 & 378 & 722 & 820 & 676 \\
\hline $\mathrm{MgO}(\mathrm{S})+\mathrm{H}_{2} \mathrm{O}(\mathrm{L}) \rightleftharpoons \mathrm{Mg}_{\mathrm{g}}(\mathrm{OH})_{2}(\mathrm{~S})$ & 644 & 277 & 614 & 649 & 598 \\
\hline $\mathrm{BaO}(\mathrm{S})+\mathrm{H}_{2} \mathrm{O}(\mathrm{L}) \rightleftharpoons \mathrm{Ba}(\mathrm{OH})_{2}(\mathrm{~S})$ & 598 & 257 & 1.052 & 1.271 & 961 \\
\hline $\mathrm{FeCl}(\mathrm{S})+6 \mathrm{NH}_{3}(\mathrm{~L}) \rightleftharpoons\left(\mathrm{Fe}\left(\mathrm{NH}_{3}\right)_{6}\right) \mathrm{Cl}_{2}(\mathrm{~S})$ & 302 & 129 & & & \\
\hline $\left.\mathrm{CaCl}_{2}(\mathrm{~S})+6 \mathrm{NH}_{3}(\mathrm{~L}) \rightleftharpoons \mathrm{Ca}\left(\mathrm{NH}_{3}\right)_{6}\right) \mathrm{Cl}_{2}(\mathrm{~S})$ & 210 & 90 & & & \\
\hline
\end{tabular}

$a_{W s / g}$ represents watt-second per gram. One Ws/g is equivalent to $2,326 \mathrm{Btu} / 1 \mathrm{~b}$.

${ }^{b}$ One bar is equivalent to $14.51 \mathrm{~b} /$ in $^{2}$. 


\section{TABLE 4. SELECTED CHARACTERISTICS AND STATUS OF VARIOUS THERMOCHEMICAL ENERGY STORAGE APPROACHES (47)}

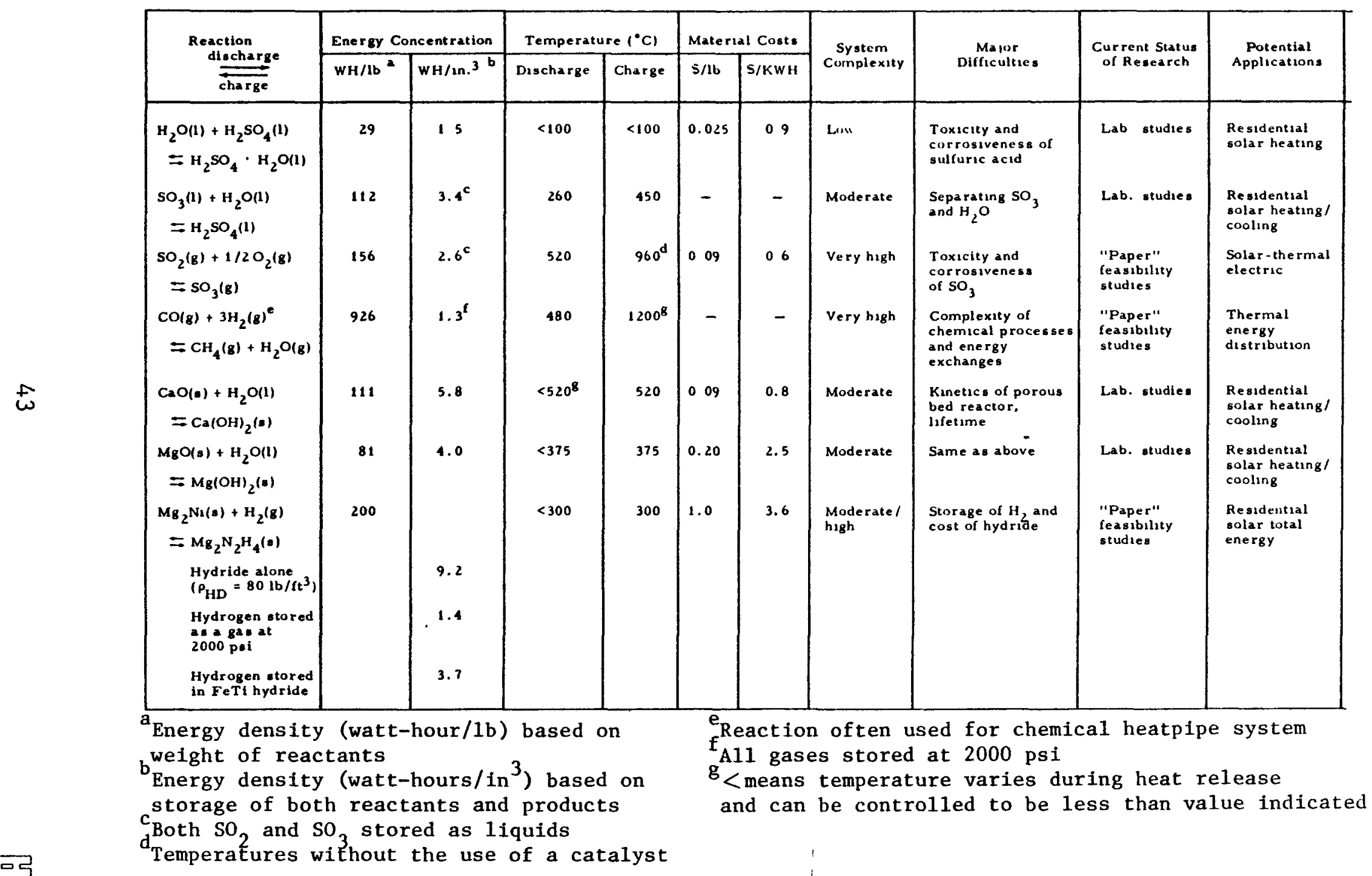


salts have been investigated $(48,49,50,51)$. However, more exploration and laboratory tests are still needed.

4. Selected Examples

The development of TCES is in the beginning stage and there is no TCES unit available for immediate commercialization. Two examples are selected for illustrative purposes to explain how TCES works.

a. Sulfuric Acid-Water Storage. The sulfuric acidwater storage is of some interest at the present time. This is because sulfuric acid is an inexpensive chemical commercially available in large quantities and the industry has accumulated extensive information. The energy storage density is approximately 120 to $200 \mathrm{Btu} / 1 \mathrm{~b}$. The disadvantage of this TCES is that the toxicity and corrosiveness of the acid are hazardous.

Rocket Research Corporation has proposed a sulfuric acid-water energy storage unit (50). It has a separator which is heated by solar energy, where the water is separated by evaporation from a sulfuric acid-water solution at a temperature of approximately $615^{\circ} \mathrm{F}$. The separated water in the form of steam is condensed and stored in a water storage tank. The remaining hot sulfuric acid at approximately 98 percent concentration passes through some heat exchangers and is stored at approximately $200^{\circ} \mathrm{F}$ in an acid storage tank. When thermal energy is required, the water and concentrated acid will be recombined in a mixer reactor where the energy will be released for heating or for absorption cooling. The diluted sulfuric acid-water solution is then stored at approximately $100^{\circ} \mathrm{F}$ in a diluted acid storage tank. The diluted acid will then be transferred to the separator where the cycle began. A simulated application of seasonal storage using a sulfuric acid-water system has been presented for a $20,000 \mathrm{sq}-\mathrm{ft}$ building located on the eastern seaboard. The schematic diagram and flow diagrams of the seasonal systems are shown in Figures 20 and 21. More detailed information is shown on Data Sheet 22 in Appendix A. Rocket Research Corporation has recently developed a sulfuric acid/ water heat pump/energy storage subsystem which operates at a temperature range of 150 to $400^{\circ} \mathrm{F}$ (68).

b. Magnesium Chloride Dihydrate System. This technology has been applied to heat pump operation and the carrier gas is water vapor (49). The process is best explained by referring to the vapor pressure-temperature diagram in Figure 22. The system is composed of a vaporizer containing liquid water, interconnected by a tube with an absorber containing magnesium chloride dihydrate (MgCl 


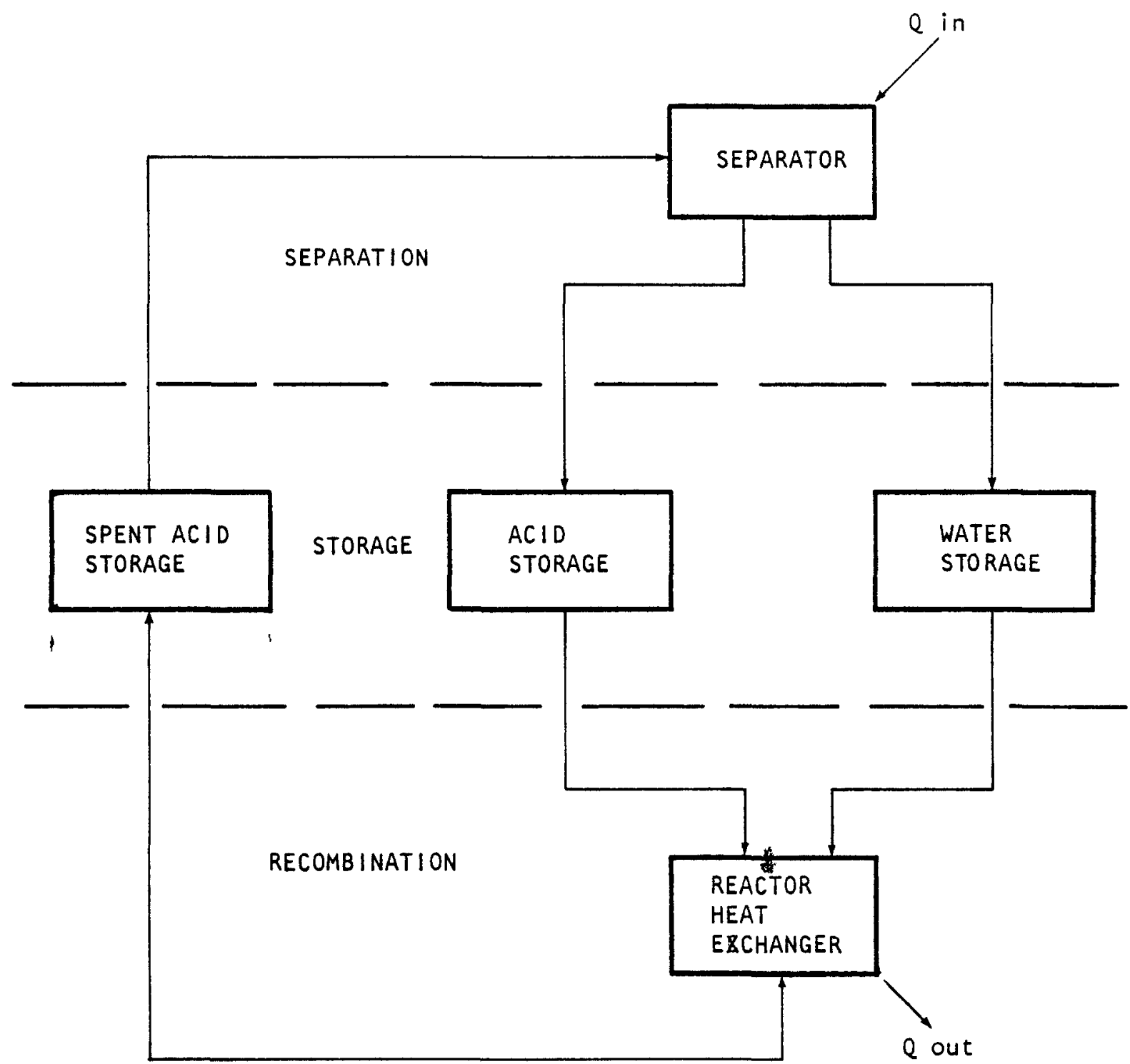

Figure 20. Schematic Diagram - Sulfuric Acid-Water System 


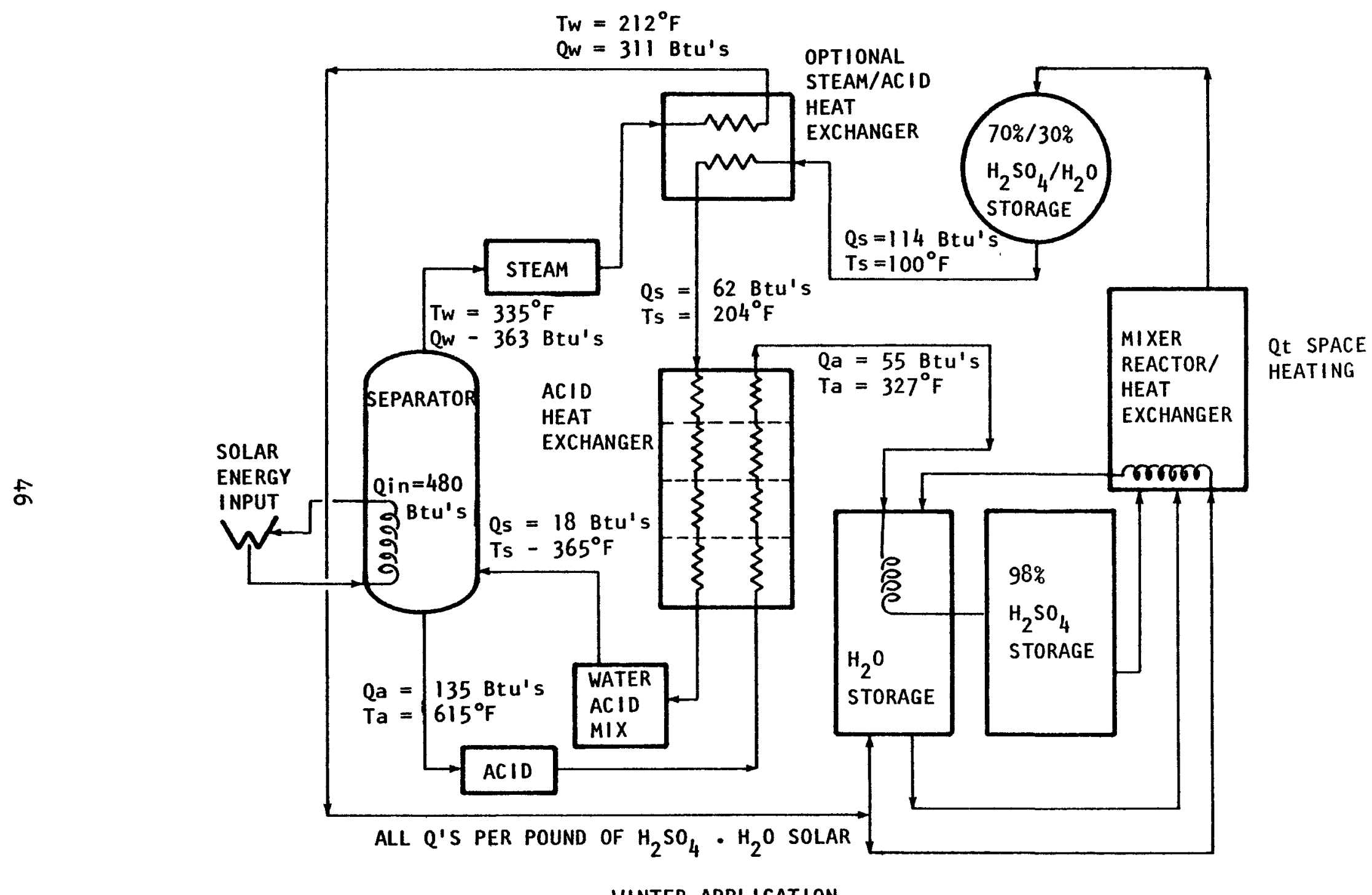

Figure 21.a. Seasonal Sulfuric Acid-Water System for Heating and Cooling of Buildings 


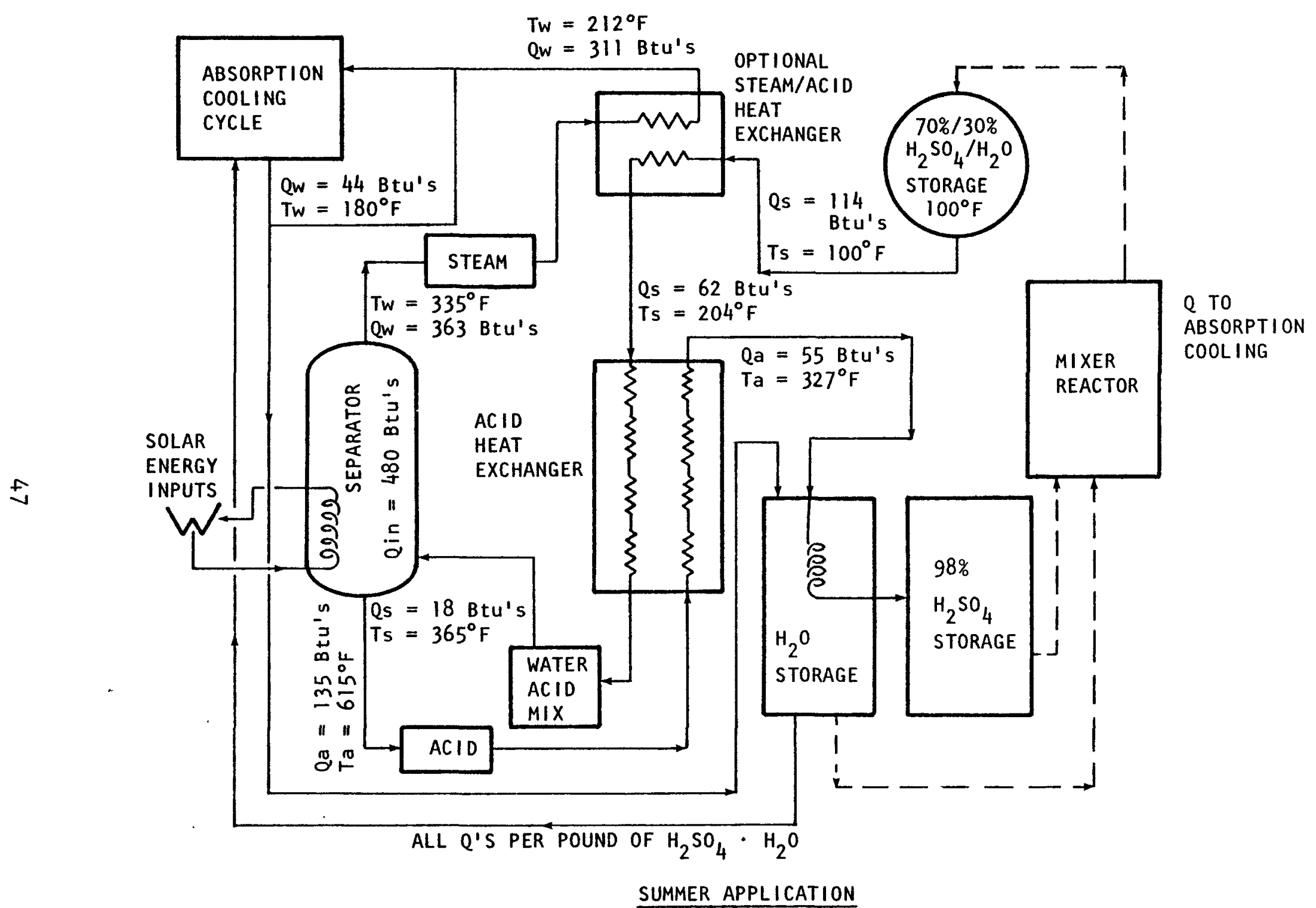

Figure 21.b. Seasonal Sulfuric Acid-Water System for Heating and Cooling of Buildings 


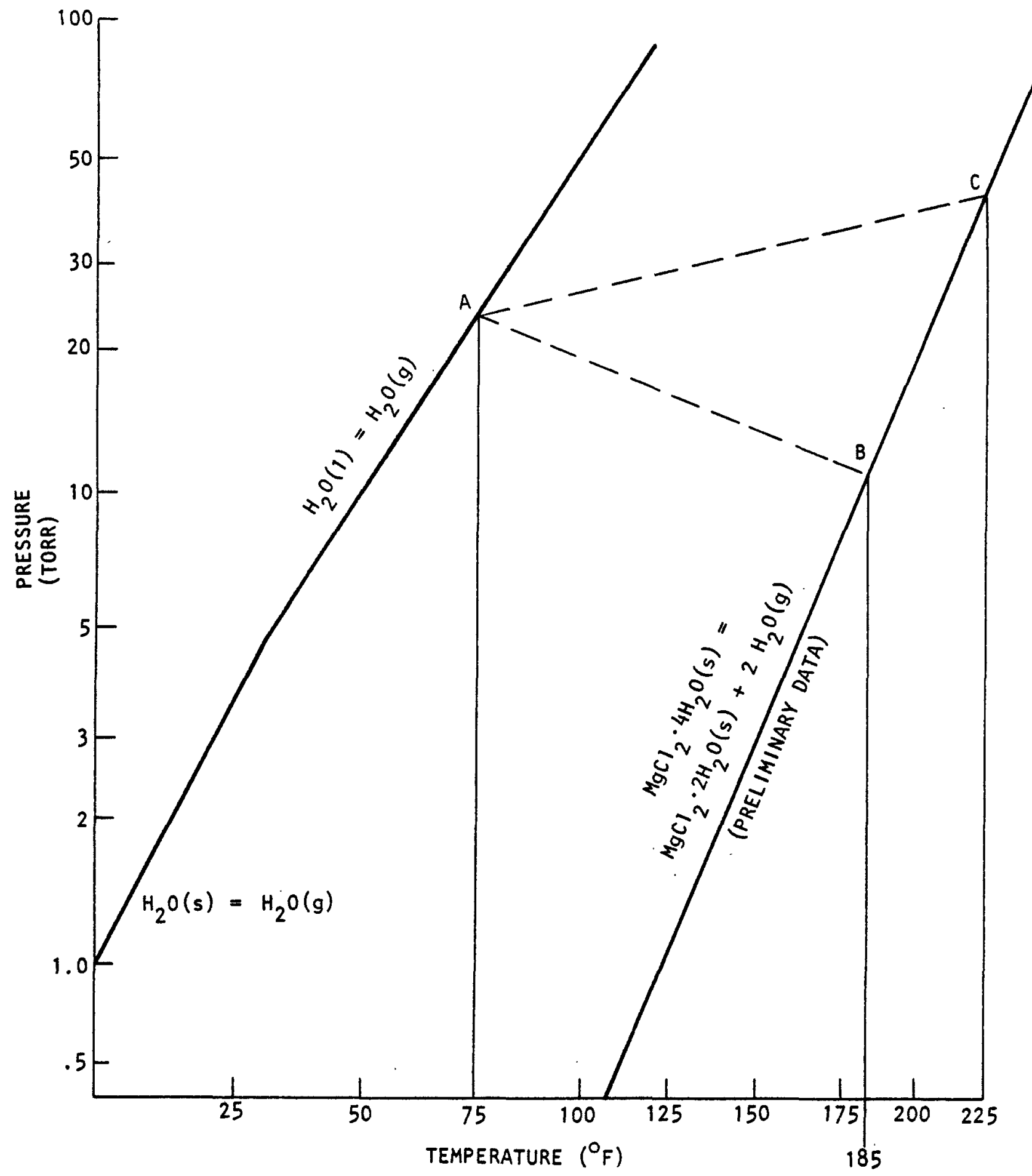

Figure 22. Vapor Pressure-Temperature Relationship for a Water-Magnesium Chloride System 
$2 \mathrm{H}_{2} \mathrm{O}$ ). In the heating mode, the water vapor pressure at $75^{\circ} \mathrm{F}$ in the vaporizer, as indicated by point $\mathrm{A}$, is much higher than that of the absorber at point B. Water vapor will be transferred through the interconnected tube to the absorber from the vaporizer. In the vaporizer, the energy is drawn from the environment. In the absorber, the water vapor will be combined with magnesium chloride dihydrate $\left(\mathrm{MgCl}_{2} \cdot 2 \mathrm{H}_{2} \mathrm{O}\right)$ to form magnesium chloride tetrahydrate ( $\mathrm{MgCl}_{2}$. $\left.4 \mathrm{H}_{2} \mathrm{O}\right)$ and energy will be released for space heating. The temperature of the absorber can be kept at $185^{\circ} \mathrm{F}$ as indicated by point $B$. The thermal energy storage density is approximately $350 \mathrm{Btu} / \mathrm{lbm}$. During the reverse cycle, solar energy is added to the absorber to raise the temperature to $225^{\circ} \mathrm{F}$ (point C), where the absorber vapor pressure will be higher than that of the evaporator represented by point A. Water vapor then will be transported to the evaporator. The excess water vapor in the evaporator will be condensed. The energy released due to condensation is dissipated to the environment. In the cooling mode, the operation is similar except that the vaporization temperature will be kept lower for space cooling purposes and the absorber temperature will also be lower to maintain a workable vapor pressure difference. The chemical heat pump for this system is shown in Figure 23. More detailed information will be found in Data Sheet 23 in Appendix A. 

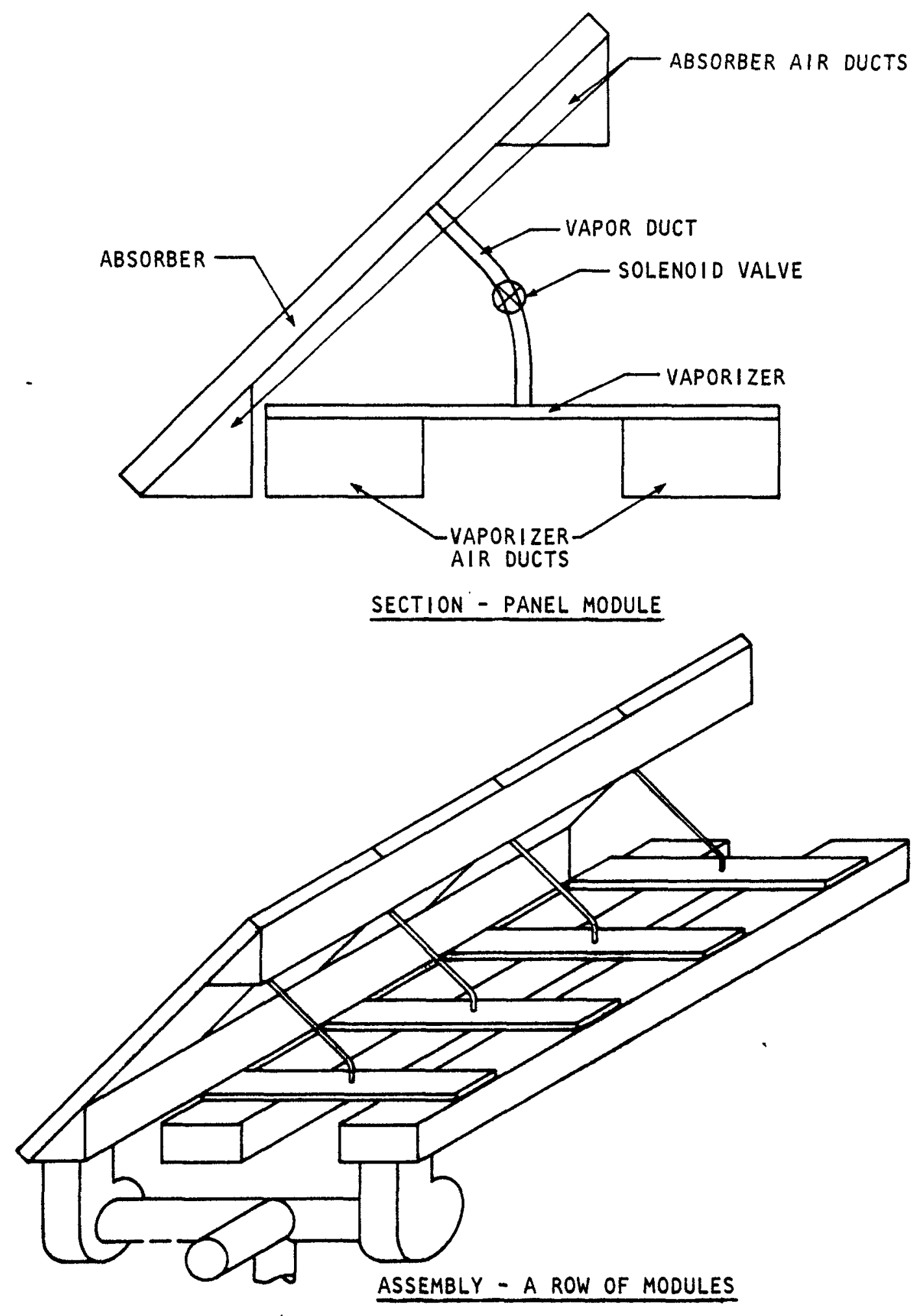

Figure 23. Magnesium Chloride Hydrate System Chemical Heat Pump 


\section{STORAGE REQUIREMENTS FOR SOLAR APPLICATIONS}

Solar applications under consideration are those paths indicated in Figure 24 for Solar Heating and Cooling of Buildings (SHACOB) and in Figure 25 for Agricultural Industrial Process Heating (AIPH) (1). Each path shows a group of applications using a certain type of energy collector to achieve a particular end use such as space heating or space cooling.

The primary subject of this chapter is the general storage requirements for each path. Storage requirements for solar applications are characterized by the following criteria:

- Storage temperature range

- Energy storage capacity requirement

- Length of storage time

- Charge-discharge rates required

- Energy losses to environment

- Acceptable cost.

These criteria, as applied to storage units for each path, are presented in Appendix B. A discussion of each item follows.

\section{A. Storage Temperature Range}

Storage temperatures are determined by the characteristics of interfacing equipment such as collectors and heat pumps, etc, which may be used in particular applications, and by the requirements of the end use. Depending on the application, thermal storage may be required over a wide range of temperatures. For the applications covered in Appendix $B$ the storage temperatures fall in the range of $0^{\circ} \mathrm{F}$ to $700^{\circ} \mathrm{F}$.

\section{B. Energy Storage Capacity Requirements}

The amount of thermal energy to be stored depends on each specific system application. Generally speaking, a storage unit should satisfy a short-term storage need of a 


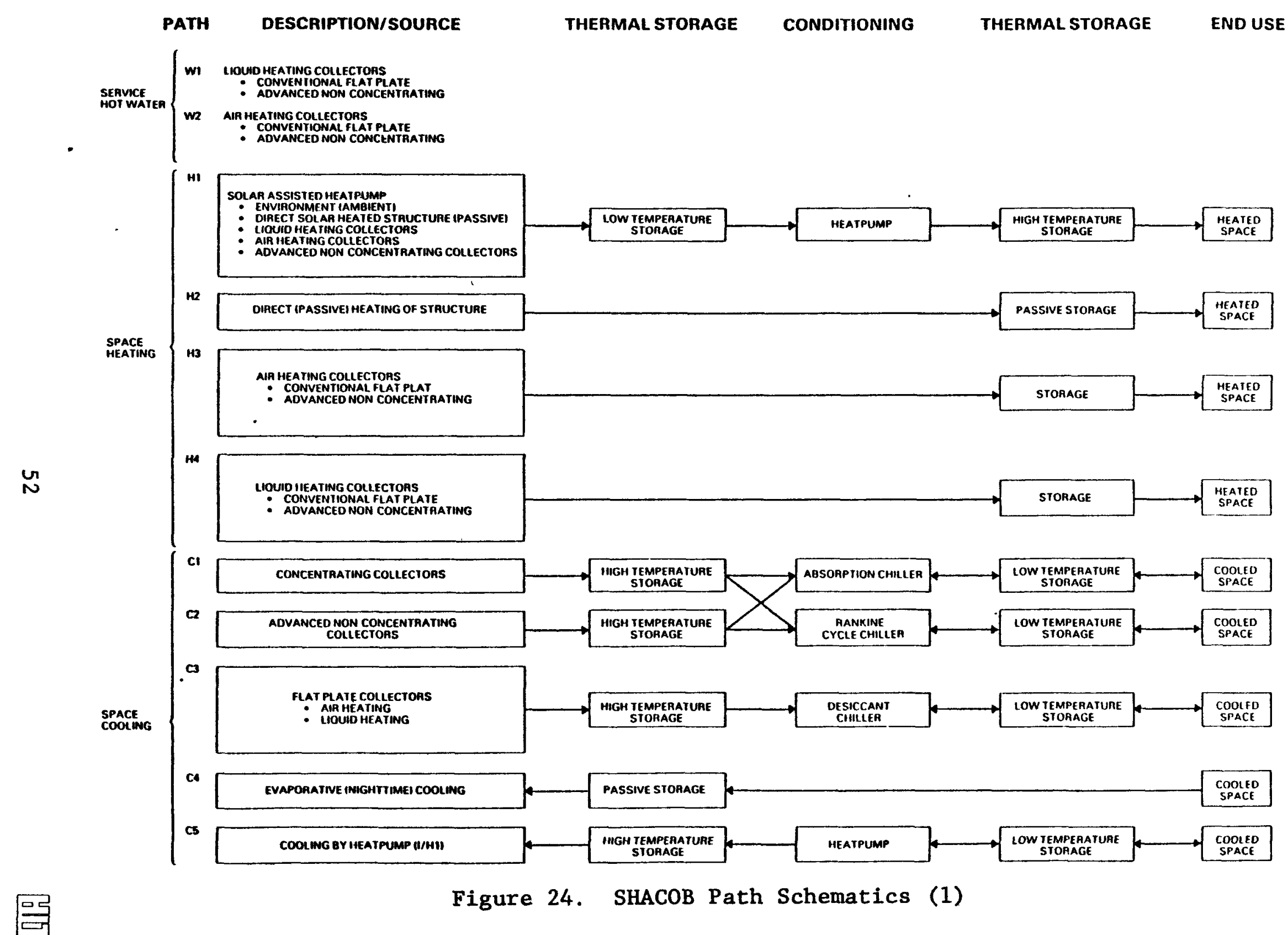




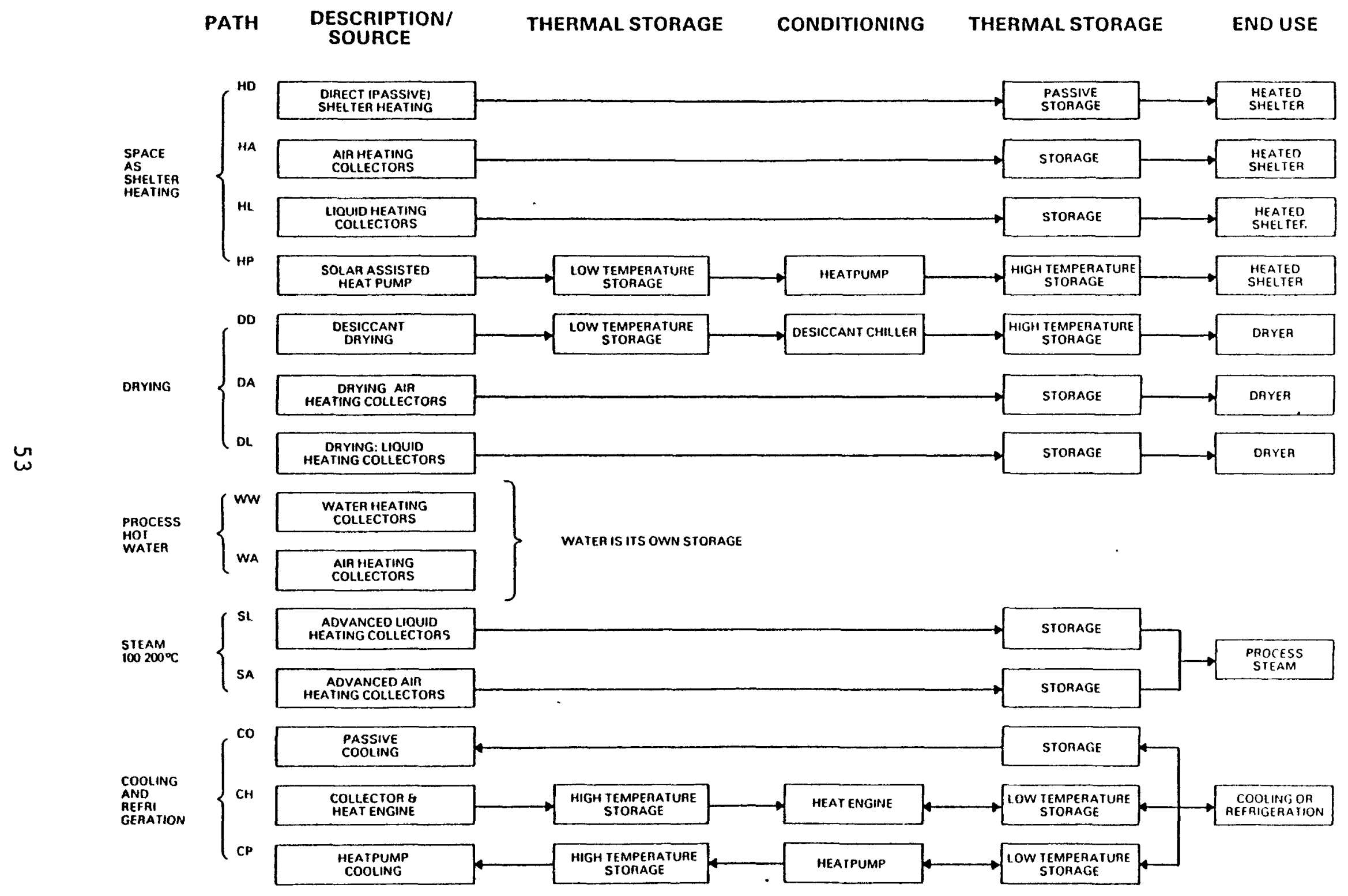

Figure 25. AIPH Path Schematics (1) 
few days at a rate of 60 to 80 percent of the daily average load during a heating or cooling season. An application using 100 percent solar energy on a short-term basis would not be economical because the collector area and storage volume would have to be large enough to meet peak loads which occur only on a few days during the heating or cooling seasons. A standby system is required if the end-use function cannot be disrupted. However, in certain geographical areas and for some systems, long-term storage such as seasonal storage can be more cost effective than short-term storage $(52,15,39)$. When storage container size increases, the construction cost per unit volume decreases. This is because the volume is a function of the cube of the dimension and the surface area of the container is a function of the square of the dimension. A large storage tank for seasonal storage can supply 100 percent solar heating or cooling and also minimize the collector area. Since the energy required for winter heating can be collected in summer at a higher insolation level, the collector area could be small compared to short-term storage. In winter on the other hand, cooling capacity can be stored for summer cooling requirements (39). The optimum amount of storage depends on the economics of all components of a complete system including nonsolar energy, labor, material, operations, and maintenance through the expected life of the system. A marginal cost analysis has been suggested by Kahan and Estes (69) in which the upper limit cost can be established for a new system by incorporating lifetime energy saving into life cycle cost analysis.

\section{Length of Storage Time}

The ideal storage duration corresponds to the desired time to hold full charge without serious thermal losses. The time period can be a few days for short-term storage or several months for long-term storage. As the temperature rises, thermal energy losses increase because of the increased temperature differential. In seasonal storage, the temperature in a storage vessel is normally below $180^{\circ} \mathrm{F}$ to minimize this loss. However, for chemical storage, the storage time is not a function of temperature. The chemicals can be stored indefinitely at ambient conditions and recombined to generate higher temperatures when needed.

\section{Energy Losses}

A general discussion regarding energy losses of a storage unit is given in this section. Energy losses from an 
above-ambient storage unit to the environment or energy gains into a below-ambient storage unit, are a function of temperature differential, storage time, and the coefficient of heat transfer. The coefficient of heat transfer can be reduced if the geometry of the container and insulation materials are properly designed. In addition to the heat transfer loss or gain of a storage unit, there is parasitic loss due to operation of controls, pumps, or fans required for the storage unit. Parasitic energy loss is normally in the form of heat generated from electrical energy. In heating applications, the parasitic loss could be recovered in a manner similar to electrical resistance heating. In cooling applications, this heating loss becomes part of the cooling load. Similarly, the heat loss from a storage tank located inside a building may be recovered for a heating system or may cause additional load for a cooling system. A storage unit designed for the short-term can tolerate a higher rate of heat loss than a long-term storage unit. To maintain a reasonably good storage efficiency of 90 percent, the heat losses should be limited to three percent per day up to several days for short-term storage, and three percent per month up to several months for long-term storage.

The larger the storage container, the greater the thermal efficiency. This is because the exposed heat transfer area per unit mass is smaller for larger containers. Calculations based on $200^{\circ} \mathrm{F}$ water stored in a $300-\mathrm{ft}$ diameter underground cavity for 90 days indicate a loss of approximately 25 percent (53). However, for $200^{\circ} \mathrm{F}$ water stored in a buried $10 \times 5 \times 3-f t$ uninsulated water tank, the heat loss over 48 hours is more than 50 percent. If a six-inch insulating blanket having a thermal conductivity of $0.25 \mathrm{Btu}$ in/ $\mathrm{ft}^{2}$ $\mathrm{hr}-{ }^{\circ} \mathrm{F}$ is applied, the same $10 \times 5 \times 3-\mathrm{ft}$ tank will lose only about 10 percent in 48 hours. Insulation is an effective method of improving storage thermal efficiency. Parasitic losses due to pump or fan operation should be included in calculations of storage unit efficiency. These losses are normally not more than three to six percent of the storage capacity. Standard methods of testing storage units based on thermal performance have been developed through ASHRAE (54).

Heat transfer for underground tanks is a complicated phenomenon depending on such factors as soil type, moisture content, water table, and capillary action. A detailed discussion is given in Reference 55. 


\section{E. Acceptable Cost}

The acceptable cost of a solar thermal storage unit is application dependent and difficult to judge without establishing a specific application. One approach is to compare the life cycle cost of a solar system with storage to the life cycle cost of a likely competitive conventional system that will achieve the same end-use purpose.

An energy storage unit is just one portion of an entire solar energy system designed either for heating and cooling of buildings, or for agricultural or industrial applications. There are many interfacing and coordinating requirements between the storage unit and the other components to insure that the entire system functions properly. The considerations given for short-term and seasonal storage apply not only to the storage devices but also to the related collector areas, heat exchangers, piping, and other interfacing requirements. Compared to short-term storage in a heating application, the collector area for seasonal storage can be small since the collector will also operate in sumer months at $a^{\prime}$ high insolation level. However, for a shortterm storage system, the collectors must operate during winter months while the insolation is at a lower level. Because there are obvious design differences in the containers of these two storage units, the piping arrangement, heat exchanger, etc., may also be different. The cost analysis should include the entire system, rather than just the storage component.

A new system to be commercially competitive, must be attractive economically when compared with existing systems. For solar heating and cooling applications, the heat pump system is one of the strongest competitors. The acceptable cost of a solar system will depend on how well it compares with a commercialiy available heat pump system for the same application. Similarly, if natural gas is available for a certain locality, the solar heating system may have to be competitive with a natural gas heating system.

A life-cycle cost analysis can successfully incorporate into the expected life span of a system the material and labor costs for construction and the future operating costs including fuel, maintenance, taxes, and insurance. The life-cycle cost analysis technique incorporated into value engineering analysis has been applied to new construction programs of the Environmental Protection Agency (EPA) and the General Services Administration (GSA). Various references (56) are also available. 
Cost information regarding storage devices in a complete system is difficult to obtain. The scope of this study does not include the development of such information. The storage component costs are scattered. An estimate of 1975 prices to construct thermal storage tanks in residential applications indicated that the cost, depending on the sizes, for concrete tanks ranged from $\$ .50$ to $\$ .67$ per gallon; steel tanks from $\$ .51$ to $\$ .70$ per gallon; wooden tanks $\$ .45$ to $\$ 1.30$ per gallon; and fiberglass-reinforced plastic tanks from $\$ .94$ to $\$ 1.77$ per gallon (55). These are partial costs of a complete system. In Appendix B, the acceptable cost does not address the actual estimate but indicates the most likely competitor of a solar system for each path. 
IV. DEVELOPMENT OF PRELIMINARY DESIGN CRITERIA

\section{A. Matching Storage Units to} Solar Applications

Based on the information gathered while characterizing thermal energy storage units and defining storage requirements for each application, potentially suitable energy storage alternatives were matched to each solar energy application. The criteria used for matching were commercial availability, temperature range, and path application. The results are shown in Figures 26 and 27.

Since design is a site specific function, hardly more than a qualitative judgment is possible. This consisted of rating the available units either good or fair in their applicability to the particular SHACOB or AIPH path. Temperature range and interface requirements are the two factors used in judging the suitability of a storage unit for a particular path.

\section{B. Development of Preliminary Design Criteria}

The objective of developing the preliminary design criteria of the solar thermal energy storage units is to establish the relationship between the thermal energy storage unit and the overall solar energy system. Design criteria for one selected storage unit for each path in Figures 26 and 27 are summarized in the following pages. Each description corresponds to a path and outlines a thermal energy storage unit which applies to that path. The selected unit for each path will satisfy path criteria and is considered one solution to those requirements. It should be noted that it is not possible to select the best match at the present time.

Most information collected in developing preliminary design criteria is obtained from the Data Sheets in Appendix $A$ and from the storage criteria in Appendix $B$. Information on storage units commercially available by 1979 is quantified in Figure 28, including availability of information on containerization, storage material, interface requirements, unit performance, operation and maintenance, design guidance, and cost.

From a designer's point of view, the intention of the preliminary design criteria is to provide a general understanding of a storage unit applied in a path rather than 


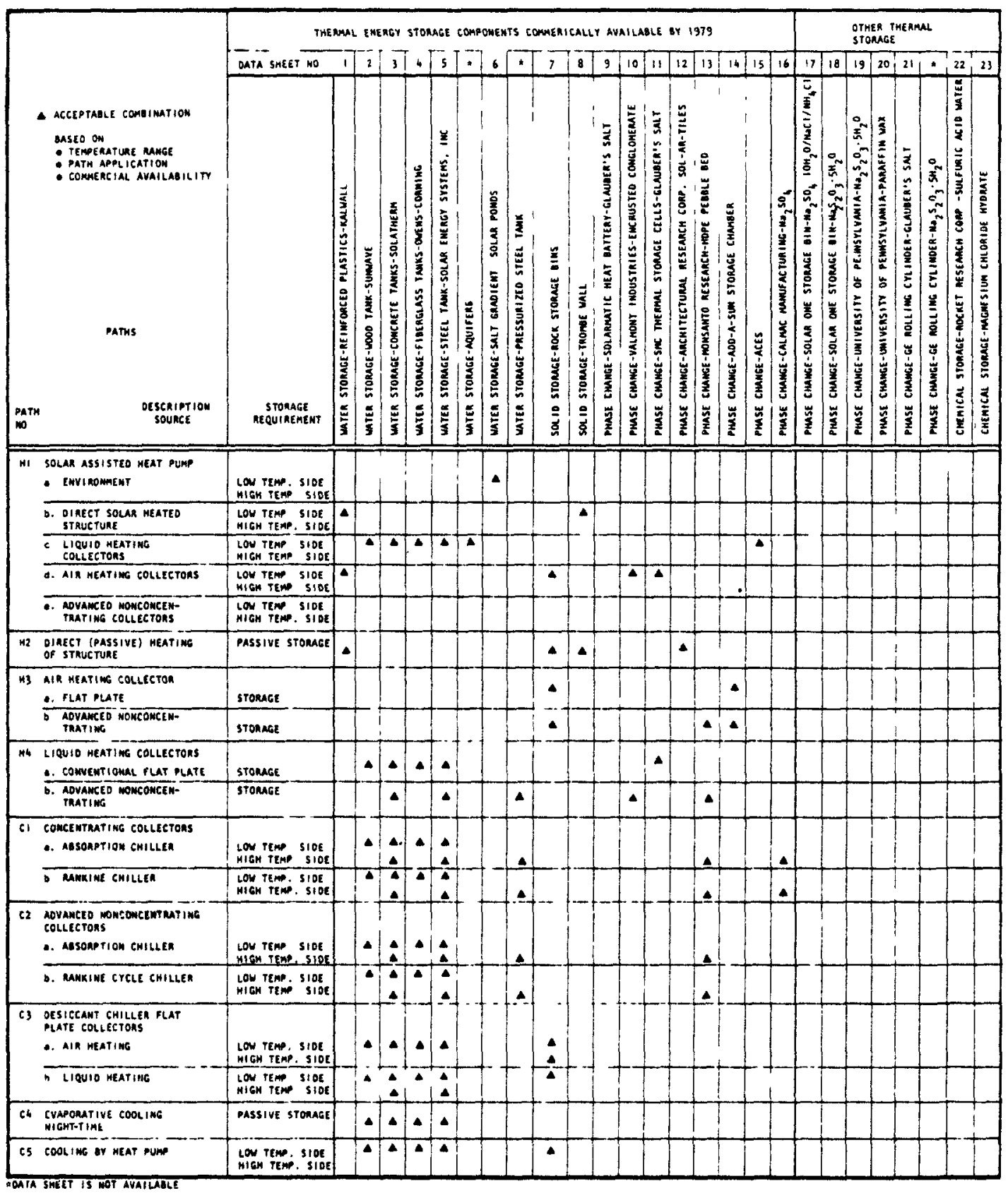

Figure 26. Matching of Thermal Energy Storage with SHACOB Paths 


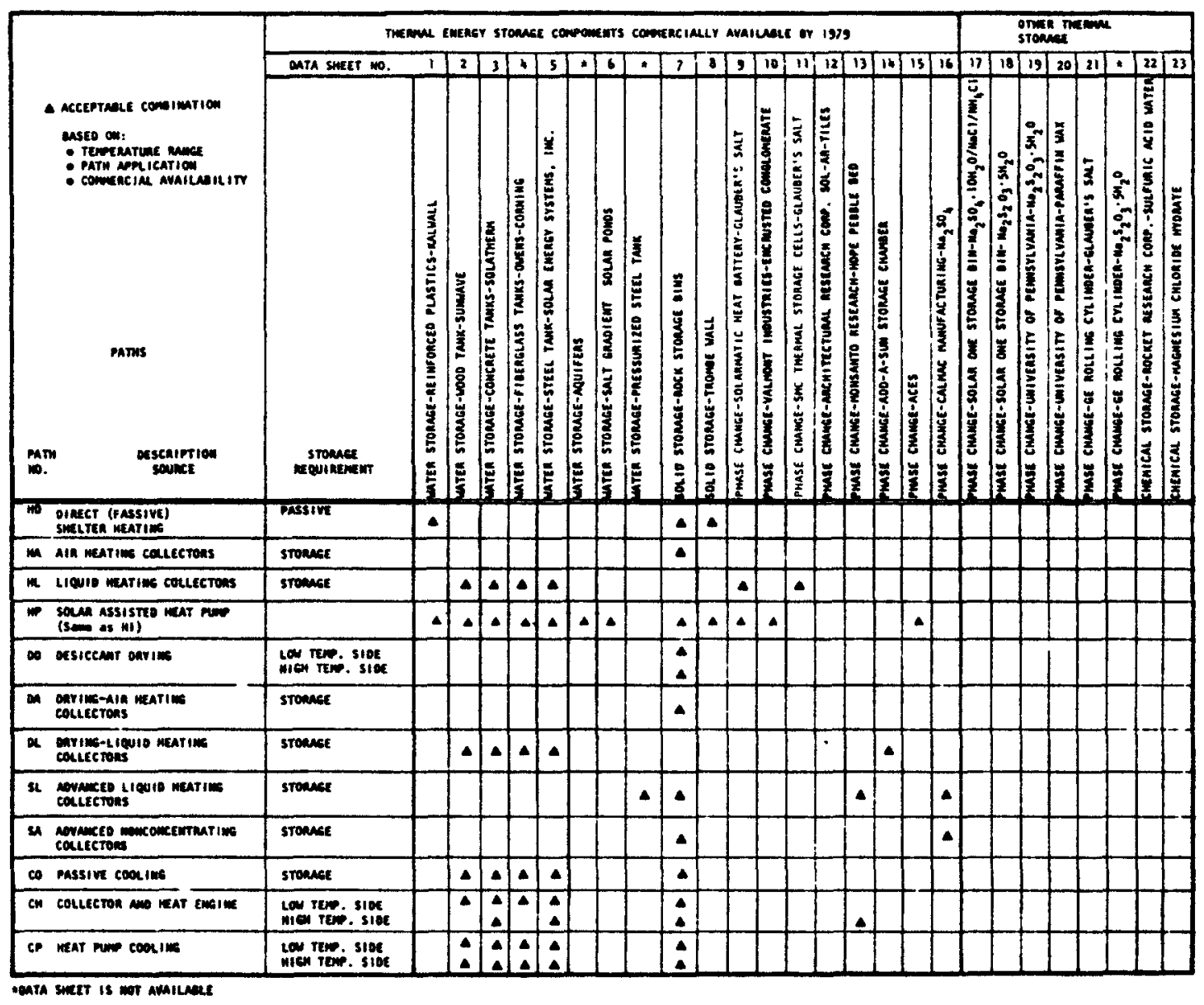

Figure 27. Matching of Thermal Energy Storage With AIPH Paths 


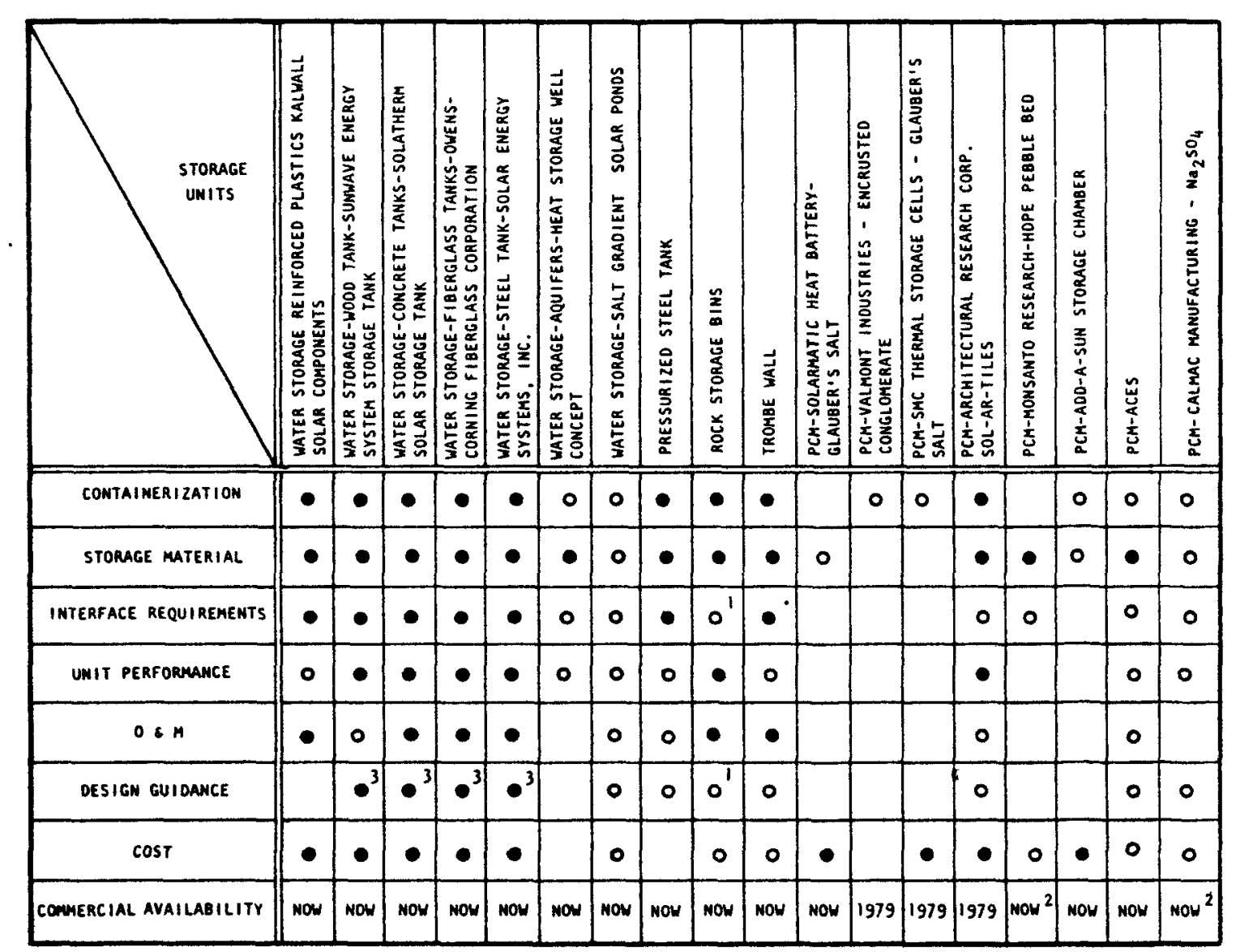

1 - Some types, such es thermosyphon designs, are not fully researched.

2 - Storage material is available, not the unit package.

3 - Heat pump interface information is scarce.

TLittle on mo imformation avallable

O SOME Imformation aVaILABle

- adequate information available

Figure 28. Survey of Available Information for Thermal Storage Units 
handbook-type details for specific design guidance. The designer would obtain from this the first-cut description of the storage unit as well as the limits and bounds in a path application. If a particular design has to be materialized, more detailed information would be needed. The items under discussion in the development of the preliminary design criteria are:

(1) Storage unit name or type, material, stage of development, and container type

(2) Interface requirements

(3) Storage performance

(a) Operating principle

(b) Temperature range

(c) Storage requirements

(d) Charge rate

(e) Discharge rate

(f) Heat losses

(4) Operation and maintenance

(5) Cost

(6) Other design considerations.

Certain cautions that may require special attention to design are provided in the discussion of other design considerations. References can be consulted for additional details if a storage design is to be further pursued. The results of this discussion for each storage type in a path application follow. 
SHACOB - Path Hla.
Solar Assisted Heat Pump Using Environment

(1) Salt Gradient Solar Pond* $(57,58,15)$.

(a) Storage material - water-salt solution.

(b) Storage container - Ponds are built using existing earth excavation techniques and conventional swimming pool or reservoir liners. Optimum materials and techniques for this application have not been defined.

(2) Interface Requirements: A water-to-air heat pump is required with a source temperature range of 40 to $100^{\circ} \mathrm{F}$. When pond temperature exceeds $100^{\circ} \mathrm{F}$ the heat pump should be by-passed to a water-to-air heat exchanger.

(3) Storage Performance:

(a) Operating principle - passive collection and sensible storage.

(b) Operating temperature -50 to $90^{\circ} \mathrm{F}$.

(c) Charge rate - dependent on available insolation, salt concentrations, and transmissivities.

(d) Discharge rate - dependent on heat exchanger size.

(e) Heat loss - dependent on pond temperature, condition and qualities of surrounding earth, and covers provided, if any.

(f) Size - solar ponds can be built in any size if space is available. The larger sizes appear to be more cost effective.

(4) Operating and Maintenance Requirements: The salt gradient must be maintained against mixing due to waves, evaporation, and disturbance. Also, biological growth (algae, bacteria) and debris in the pond will need to be removed periodically.

(5) Cost: $140 \mathrm{~m}^{2}$ pond - $\$ 5,850$, estimated in Reference 57 .

* Whether salt gradient pond can be considered as Path Hla using environment is still subject to argument. 
(6) Other Design Considerations: In the Ohio area a solar pond should be about equal in volume and surface area to the space it is going to heat. 


\section{SHACOB - Path H1b.}

Solar Assisted Heat Pump Using Direct Solar

Heated Structure

(1) Sun-Lite Storage Tubes $(59,60)$.

(a) Storage material - water.

(b) Stage of development - commercially available.

(c) Storage container - fiberglass-reinforced plastic tubes (e.g., Kalwall or equivalent).

(2) Interface Requirements:

(a) Storage units must be located behind a south-facing window wall.

(b) Ducting must be provided to connect plenum area around units with evaporator side (heating cycle) of air-to-air heat pump.

\section{(3) Storage Performance;}

(a) Operating principle - passive collection and sensible storage. See Figure 29.

(b) Operating temperature - Temperature of air supply to evaporator coil of heat pump is from 50 to $90^{\circ} \mathrm{F}$. Temperature of water in the tubes is $60^{\circ}$ to $120^{\circ} \mathrm{F}$.

(c) Storage requirement - storage should be short-term (1-2 days) at 60 to 80 percent of the seasonal average daily load.

(d) Charge rate - A daily insolation of 1500 $\mathrm{Btu} / \mathrm{ft}^{2}$ will provide a temperature rise of 20 to $25^{\circ} \mathrm{F}$.

(e) Discharge rate - $1400 \mathrm{Btu} / \mathrm{hr}$ for a tube 12 inches in diameter and 10 feet high. 2100 $\mathrm{Btu} / \mathrm{hr}$ for a tube 18 inches in diameter and 10 feet high. Air flow velocity is under 500 fpm at $30^{\circ} \mathrm{F}$ temperature differential.

(f) Heat loss - heat loss through the glazing is relatively high since insulation is not provided on the surface of the tube. 


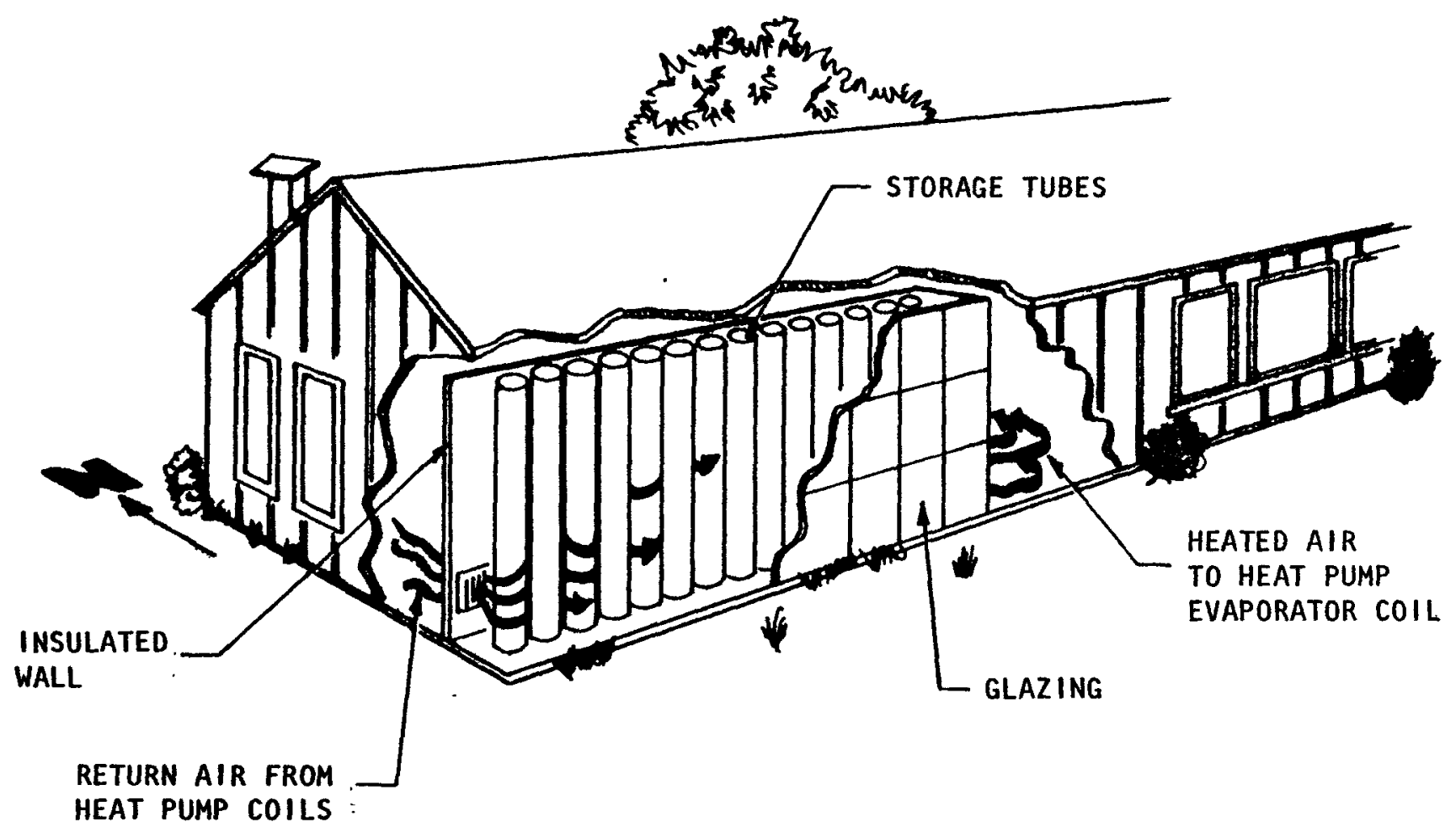

Figure 29 - Solar Vater Wall Assisted Heat Pump System 
(4) Operating and Maintenance: Shade is required to cut off insolation in summer. No maintenance work is required for storage tubes.

(5) Cost: $\$ 10 / \mathrm{ft}^{3}$ for small tubes to $\$ 3 / \mathrm{ft}^{3}$ for large tubes.

(6) Other Design Considerations:

(a) South-facing exposure is required.

(b) Water supply and drain should be provided.

(c) Data regarding physical dimensions and available capacities are given in References 59 and 60 . A design manual is available in Reference 60 . 
SHACOB - Path H1c.

Solar-Assisted Heat Pump With Liquid

Heating Collectors

(1) Solarmatic Heat Battery

(a) Storage material - Glauber's Salt.

(b) Storage container - steel tank with heat exchanger.

(c) Stage of development - available commercially in small quantities.

(2) Interface Requirements:

(a) Heat source for charging is a flat plate hot water collector.

(b) Unit will operate with a water-to-air heat pump.

(3) Storage Performance:

(a) Operating principle - latent storage.

(b) Temperature range - storage tank $90^{\circ}$.

(c) Storage requirement - The solar collectorstorage combination should be sized to supply all the heat input needs of the heat pump.

(d) Charge rate - not available from the manufacturer.

(e) Discharge rate - not available from manufacturer.

(f) Heat loss - not available from manufacturer.

(4) Operation and Maintenance:

(a) It should be determined if the charge rate of a solidified tank is adequate under real operating conditions.

(b) A test of performance should be made by an independent lab to determine operating and maintenance characteristics. 
(5) Cost: $\$ 2,278$ F.O.B. for a $340,000 \mathrm{Btu} / 43 \mathrm{ft}^{3}$ system.

(6) Other Design Considerations: To optimize such a system a heat pump with an evaporator range of around $90^{\circ} \mathrm{F}$ is needed. 
SHACOB - Path HId.

Solar-Assisted Heat Pump Using Air Heating Collectors

(1) Valmont Energy System - Encrusted Conglomerate.

(a) Storage material - Glauber's salt.

(b) Storage container - polyethylene trays.

(c) Stage of development - available in 1979.

(2) Interface Requirements:

(a) Heat source for charging is a flat plate hot air collector.

(b) Should operate in series with an air-to-air heat pump and a forced air circulating system.

(3) Storage Performance:

(a) Operating principle - latent storage. .

(b) Operating temperature - Collectors and heat pump should be chosen for optimum performance around the $89^{\circ} \mathrm{F}$ phase-change temperature of the Glauber's salt.

(c) Storage requirement - not available.

(d) Charge rate - not available.

(e) Discharge rate - not available.

(f) Heat loss - no loss if the storage unit is in the conditioned space, otherwise heat loss depends on the insulation provided.

(4) Operating and Maintenance: No maintenance is required for the storage unit. No estimate of its life has been given.

(5) Cost: Not available from manufacturer.

(6) Other Design Considerations: At this time (10/78) the charge and discharge rates for the unit are not available. This information should be obtained before incorporating this storage unit in any system. 
SHACOB - Path H2.

Direct Passive Heating of Structures

(1) SOL-AR-TILE

(a) Storage material - Eutectic of Glauber's salt.

(b) Stage of development - Commercially available.

(c) Storage container - Polymer concrete.

(2) Interface Requirements:

(a) A south-facing window-wall is required.

(b) Reflection device is required if tiles are ceiling mounted. Reflective louvers are suggested.

(3) Storage Requirements:

(a) Operating principle - latent storage.

(b) Operating temperature - liquid-to-solid phase change occurs at approximately $73^{\circ} \mathrm{F}$.

(c) Discharge rate - maximum $17 \mathrm{Btu} / \mathrm{hr}-\mathrm{ft}^{2}$.

(d) Heat loss - none, since the storage is within the conditioned space.

(e) Physical dimensions - each tile is $24 \times 24 \mathrm{x}$ $1-1 / 4$ inches.

(f) Storage requirement - The tile area should be twice the south window area. The window area is found by taking 80 percent of the heat loss for March (March is an average heating month) and dividing that product by March's solar gain through one square foot of glazing, as shown in the following eqution:

$\mathrm{HL}_{\mathrm{M}} \times 80 \% / \mathrm{SHG}_{\mathrm{M}}=\mathrm{AREA}_{W}$ 
where: $\mathrm{HL}_{\mathrm{M}}$ = March heat loss.

$$
\begin{aligned}
\mathrm{SHG}_{\mathrm{M}}= & \text { March solar heat gain } \\
& \text { through one square foot } \\
& \text { of glazing. } \\
\text { AREA }_{\mathrm{W}}= & \text { Window area. }
\end{aligned}
$$

(4) Operation and Maintenance: Shading is required during the summer. Louvers can be used to reflect radiation outward in the summer and direct it onto the tiles in the winter.

(5) Cost: $\$ 3$ to $\$ 3.5$ per tile ( $\$ .75$ to $\$ .88$ per square foot), $\$ 3,400$ per MBtu of storage.

(6) Other Design Considerations:

(a) Southern exposure is required.

(b) Tiles must be mounted horizontally.

(c) Overheating is eliminated because of low phase-change temperature. 


\section{SHACOB - Path H3. Air Heating Collector}

(1) Rock storage bin.

(a) Storage material - washed river rocks.

(b) Stage of development - fully developed.

(c) Storage container - Constructed on site. Bin can be made of wood, concrete, or lined hole.

(2) Interface Requirements: Ducts, blowers, and controls.

(3) Storage Performance

(a) Operating principle - sensible storage.

(b) Temperature range $-100^{\circ} \mathrm{F}$ to $180^{\circ} \mathrm{F}$.

(c) Storage requirement - Rogk requirements are usually 50 to $100 \mathrm{lbs} / \mathrm{ft}^{2}$ of collector area.

(d) Air flow rate - The superficial velocity (flow rate/cross section area) should be between 15 and $25 \mathrm{ft} / \mathrm{min}$.

(e) Air flow direction - To optimize the benefit of temperature stratification, the air flow should be downward during the charging mode and upward during the discharge mode. In any case, charge and discharge flows should be in opposite directions.

(4) Operation and Maintenance Requirements: If rocks are not sufficiently cleaned the air filters will need to be changed often.

(5) Cost: Cleaned gravel costs around $\$ 6.50$ per ton. Delivery costs range from $\$ 3$ to $\$ 4$ per ton.

(6) Other Design Considerations: Uniform size rocks must be used to insure sufficient air space around rocks. Rock settling can be avoided by using chicken wire mesh in horizontal layers. The rock bed must be kept dry to prevent fungal growth. 
(1) Water Storage.

(a) Storage material - water.

(b) Stage of development - commercially available.

(c) Storage container - Concrete, wood, reinforced plastic, and steel tanks are commercially available.

(2) Interface Requirements: Heat exchangers.

(3) Storage Performance:

(a) Operating principle - sensible storage.

(b) Operating temperature - Water temperature in the tank should be 110 to $160^{\circ} \mathrm{F}$.

(c) Storage requirement - approximately 3 gallons per square foot of collector.

(d) Charge rate - dependent on heat exchanger.

(e) Discharge rate - dependent on heat exchanger.

(f) Heat loss - dependent on size, configuration, storage temperature and amount of insulation of the storage tank.

(g) Available size - Tanks may be bought or custom built to meet any size requirement.

(4) Operation and Maintenance: Anticorrosion additives, freeze protection, and periodic upkeep of pumps may be required.

(5) Costs: Dependent on the type of tank chosen. 
SHACOB - Path C1.

Concentrating Collectors for Space Cooling

(1) Water storage in steel pressurized tanks (61).

(a) Storage material - water.

(b) Stage of development - commercially available.

(c) Storage container - steel pressurized tank.

(2) Interface Requirements: Heat exchangers from collectors to storage and from storage to chiller.

(3) Storage Performance:

(a) Operating principle - sensible heat storage.

(b) Temperature range -185 to $400^{\circ} \mathrm{F}$.

(c) Storage requirement - capacity equal to 24 to 28 hours of chiller energy requirement.

(d) Charge rate - dependent on heat exchanger sizing only.

(e) Discharge rate - dependent on heat exchanger sizing only.

(f) Heat loss - dependent on tank insulation thickness.

(g) Size - available in any size.

(4) Operation and Maintenance: A corrosion inhibitor additive in the water is recommended.

(5) Cost: $\$ 2$ to $\$ 4$ per gallon, depending on size of tank and pressure range.

(6) Other Design Considerations:

(a) Water supply and drain should be provided.

(b) Must meet ASME Boiler Code and Local and State Code for Pressure Vessels.

(7) Design Data: See ASME Boiler Code. 
(1) Water storage in steel or concrete tanks.

(a) Storage material - water.

(b) Stage of development - commercially available.

(c) Storage container - steel or concrete tank.

(2) Interface Requirements: Heat exchangers from collectors to storage and from storage to chiller.

(3) Storage Performance:

(a) Operating principle - sensible heat storage.

(b) Temperature range -180 to $210^{\circ} \mathrm{F}$.

(c). Storage requirement - capacity equal to 24 to 48 hours of chiller energy requirement.

(d) Charge rate - dependent upon heat exchanger sizing only.

(e) Discharge rate - dependent on heat exchanger sizing only.

(f) Heat loss - dependent on tank insulation thickness (optimum insulation thickness R-30 to $R-50)$.

(4) Operation and Maintenance: A corrosion inhibitor additive in the water is recommended.

(5) Cost: $\$ 1$ to $\$ 3$ per gallon, depending on type and size of tank.

(6) Other Design Considerations: Water supply and drain should be provided. 


\section{SHACOB - Path C4. \\ Evaporative Nighttime Cooling}

(1) Skytherm System $(62,63,64,65)$.

(a) Storage material - water.

(b) Stage of development - commercially available.

(c) Storage container - Neoprene water bags or swimming pool type liners with transparent covers.

\section{(2) Interface Requirements:}

(a) Roof must be highly conductive to allow for adequate heat transfer between the occupied space and the roof pond.

(b) A movable insulation must be provided to cover the roof during the sunlight hours.

\section{(3) Storage Performance:}

(a) Operating principle - Water, periodically sprayed on the bagged roof ponds, evaporates to cool the water in the bags. Additional cooling occurs through skyward radiation. During the day building air temperature is lowered by convective heat transfer to the cooled roof pond.

(b) Temperature range - If correctly designed the water pond temperature stays around $67 \pm 2^{\circ} \mathrm{F}$.

(c) Storage requirement - water volume suitable to meet cooling load in a diurnal cycle.

(d) Charge rate - depends on radiation and evaporation cooling gains and convective cooling losses.

1. Radiation heat flow is determined by the temperature of the pond and the ambient air, and the dew point of the surrounding atmosphere which determines the emissivity and absorptivity of the sky $(62,63)$. Evaporation is related to the water temperature and 
the wind speed by the following equa-

tion:

$\begin{aligned} Q_{\text {evap }}= & 0.093 \times \text { latent heat of } \\ & \text { vaporization } \times(1+0.38 \mathrm{~V})(\mathrm{Pv})\end{aligned}$

Where:

$\mathrm{V} \quad=$ Wind speed in miles per hour.

Pv = Difference in pond and atmosphere vapor pressures in inches of mercury.

$Q_{\text {evap }}=\begin{aligned} & \text { Evaporatiye cooling gain in } \\ & \text { Btu/hr-ft }\end{aligned}$

2. Convective cooling losses occur when the nighttime ambient is higher than storage temperature.

(e) Discharge rate - depends on ceiling construction and its conduction and radiation characteristics.

(f) Heat loss - Loss of cooling capacity due to inflow of thermal energy from ambient air depends on the $R$ value of the movable insulation provided and the temperature differential.

(4) Operation and Maintenance: Opening and closing of the movable insulation may be done manually or automatically. Some maintenance will be required for moving parts and control elements.

(5) Cost: Depends on location, prevailing winds, earthquake region, and architecture. $\$ 3 / \mathrm{ft}^{2}$ more than a conventional house at Atascader (65).

(6) Other Design Considerations: Phillip W.B. Niles, California Polytechnic State University, has developed a noncomputer model to predict internal building temperature swing (65). 
(1) Water storage.

(a) Storage material - water.

(b) Stage of development - commercially available.

(c) Storage container - steel tank with heat exchanger.

(2) Interface Requirements: Heat exchangers.

(3) Storage Performance:

(a) Operating principle - sensible storage.

(b) Temperature range -35 to $50^{\circ} \mathrm{F}$.

(c) Storage requirement - information not available.

(d) Charge rate - dependent on heat exchanger sizing.

(e) Discharge rate - dependent on heat exchanger sizing.

(f) Heat gain - dependent on tank insulation, water temperature, and ambient temperature.

(4) Operation and Maintenance: Corrosion protection may be necessary.

(5) Cost: $\$ 6$ to $\$ 3$ per gallon, depending on type and size of tank. 
-

- 
(6) Other Design Considerations: Uniform size rocks must be used to insure sufficient air space around rocks. Rock setting can be avoided by using chicken wire mesh in horizontal layers. 
AIPH - Path HL.

Liquid Heating Collectors for Agricultural structures

(1) Water storage (66).

(a) Storage material - water.

(b) Stage of development - commercially available.

(c) Storage container - Concrete, wood, reinforced plastic, and steel tanks are commercially available.

(2) Interface Requirements: Heat exchangers.

(3) Storage Performance:

(a) Operating principle - sensible storage.

(b) Temperature range - the operating temperature depends on the application. If the water-to-air heat exchanger is used for storage the temperature should be 40 to $50^{\circ} \mathrm{F}$ above the desired temperature in the conditioned space.

(c) Storage requirement - approximately 3 gallons per square foot of collector.

(d) Charge rate - dependent on heat exchanger sizing.

(e) Discharge rate - dependent on heat exchanger sizing.

(f) Heat loss - Depends on the storage temperature, ambient air temperature, and insulation thickness. Heat loss is prevented by locating the storage tank inside the shelter.

(4) Operation and Maintenance: Corrosion protection may be necessary. Associated pumps and ancillary equipment will require maintenance.

(5) Cost: $\$ 1$ to $\$ 3$ per gallon, depending on type and size of tank chosen.

(6) Other Design Criteria: The current sources of thermal energy for agricultural products are liquid propane (LP), methane, and electricity. 
Much is known about liquid-collector heating and water storage for space heating. However, until the cost of such systems appears feasible to the poultry or animal producer - they are not likely to make much impact. 


\section{AIPH - Path DA Drying-Air Heating Collectors
Drying}

(1) Rock storage bin.

(a) Storage material - washed river rocks.

(b) Stage of development - fully developed.

(c) Storage container - Constructed on site. Bin can be made of wood, concrete, or lined hole.

(2) Interface Requirements: Ducts, blowers, or controls.

(3) Storage Performance:

(a) Operating principle - sensible storage.

(b) Temperature range - the temperature range is determined by the item to be dried. For higher collector efficiencies the temperature range should be no greater than $120^{\circ} \mathrm{F}$.

(c) Storage requirement - dependent on the application being supplied.

(d) Air flow rate - The superficial velocity (flow rate/cross section area) should be between 15 and $25 \mathrm{ft} / \mathrm{min}$. These figures are optimized for charge and discharge and may have to be changed to meet air flow requirement for drying.

(e) Air flow direction - To optimize the benefit of temperature stratification, the air flow should be downward during charging mode and upward during discharge mode. In any case, charge and discharge flows should be in opposite directions.

(4) Operation and Maintenance Requirements: If rocks are not sufficiently cleaned before installation the air filters will need to be changed often.

(5) Cost: Cleaned gravel costs around $\$ 6.50$ per ton. Delivery costs range from $\$ 3$ to $\$ 4$ per ton.

(6) Other Design Considerations: Uniform size rocks must be used to insure sufficient air space around 
rocks. Rock settling can be avoided by using chicken wire mesh in horizontal layers. 
AIPH - Path DL.

Liquid Heating Collectors

(1) Water Storage (67).

(a) Storage material - water.

(b) Stage of development - commercially available.

(c) Storage container - Concrete, wood, reinforced plastic, and steel tanks are commercially available.

(2) Interface Requirements: Heat exchangers.

(3) Storage Performance:

(a) Operating principle - sensible storage.

(b) Temperature range - dependent on application being supplied.

(c) Storage requirement - This is very application dependent. If the time from harvest to obtaining the dryed crop is critical, storage can make the drying time comparable to that obtained with conventional methods. If the drying period duration is not critical storage may be small or not necessary at all.

(d) Charge rate - dependent on heat exchangers.

(e) Discharge rate - dependent on heat exchanger sizing.

(f) Heat loss - dependent on the insulation provided, the storage temperature and the ambient conditions.

(4) Operation and Maintenance: Corrosion protection may be necessary. Associated pumps and ancillary equipment will require maintenance.

(5) Cost: $\$ 1$ to $\$ 3$ per gallon, depending on type and size of tank chosen.

(6) Other Design Considerations: It is more difficult to obtain the temperature controlled conditions necessary for drying certain crops than with con- 
ventional systems. For some crops this will require more elaborate control strategy than the usual

space heating solar system. 
AIPH - Path CO.

Passive Cooling

The selected unit is a Skytherm described in Path $\mathrm{C} 4$. The application of such a unit would be identical except that greater temperature swings are tolerated by most animals. 


\section{AIPH - Path $\mathrm{CH}$. \\ Process Cooling Using a Heat Engine}

Storage requirements for this path are identical to Paths $\mathrm{Cl}$ and $\mathrm{C} 2$, depending on the collector selected (concentrating or advanced non-concentrating). 
AIPH - Path HP.

Solar Assisted Heat Pump

Storage requirements for this path are identical to Path H1 for applications with temperatures similar to those used in SHACOB. 


\section{REFERENCES}

1. Davis, J.M. "Thermal Energy Storage Research and Development Program Status Report and Plan." Conservation and Solar Applications. DOE, February 1978.

2. Miller, W., and J. Babor. General Chemistry. Wm. C. Brown Company, 1965.

3. "Product Classications." Solar Engineering Magazine. December 1977, p. 68.

4. Kalwall Corporation. Solar News. No. 5A, 1978, p. 6.

5. Personal communication with Kalwall Corporation engineers, August 1978 .

6. Acorn Structures, Inc. "The Sunwave Energy System Storage Tank." Technical Bulletin. Acorn Structures, Inc., Concord, Massachusetts.

7. Personal communication with Acorn Structures Marketing Agent, August 1978.

8. Marketing information sheet from Solatherm Corporation, Lynchburg, Virginia, supplied in July 1978.

9. Personal communication with Solatherm Corporation engineers, August 1978.

10. Owens-Corning Fiberglass Corporation, Pub. No. 1 DE6494-H.

11. Personal communication with Dan Sugaski, Market Manager Underground Tanks, Owens-Corning Fiberglass Corporation, August 1978.

12. Personal communication with Nate Brushells of Solar Energy Systems, Inc., August 1978.

13. Paul Withrush, Ed. A Dictionary of Mining, Mineral and Related Terms. U.S. Department of the Interior, 1968.

14. Warnar, J.C., F.J. Mulz and T.E. Jones. Subsurface Waste-Heat Storage: Experimental Study, Final Report. Auburn University, June 1977. 
15. Zangrado, F., and H.C. Bryant. "A Salt Gradient Solar Pond." Solar Age. April 1978, p. 21.

16. Riaz, M., P.L. Blackshear, Jr., and H.O. Pfannkuch. "High-Temperature Energy Storage in Native Rocks." In: Proceedings A Joint Conference 1976 of the American Section of the International Solar Energy Society and the Solar Energy Society of Canada, Inc.. Winnepeg, August 15th-20th, 1976, Vol. 8.

17. Blackshear, et al. "Gravel-filled Trenches in Earth for Annual Thermal Energy Storage." Proceedings of the 1977 Annual Meeting American Section of the International Solar Energy Society. Orlando, June 6-19, 1977, pp. 16.1616 .19 .

18. Eshleman, et al. "A Numerical Simulation of Heat Transfer in Rock Beds." Proceedings of the 1977 Annual Meeting American Section of the International Solar Energy Society. Orlando, June $6-19,1977, \mathrm{pp} .17 .21-17.25$.

19. H.O. Pfannkuch, M.H. Edens. "Rock Properties for Thermal Energy Storage Systems in the $0^{\circ}$ to $500^{\circ} \mathrm{C}$ Range." Proceedings of the 1977 Annual Meeting American Section of the International Solar Energy Society. Orlando, June $6-19,1977$, pp. $18.5-18.9$.

20. Ehanessian, P., and W.W. S. Charters. "Thermal Simulation of a Passive Solar House Using a Trombe-Michel Wall Structure." Solar Energy, Vol. 20, pp. 275-281.

21. Altman, M., et al. Conservation and Better Utilization of Electric Power by Means of Thermal Energy Storage and Solar Heating, Phase 1, Summary Report, NSP, University of Pennsylvania National Center for Energy Management and Power, Oct. 1, 1971, pp. 2-10.

22. Marionowski, L.G., H.C. Maru, and E.H. Camara. "Latent Heat Thermal Energy Storage at High Temperature." Proceedings of the Second Southeastern Conference on Application of Solar Energy. Baton Rouge, April 19-22, 1976, pp. 451-460.

23. Humphries, W.R., and I. Griggs. A Design Handbook for Phase Change Thermal Control and Energy Storage Devices. NASA Technical Paper 1074/1075, November 1977. 
24. Lane, G.A., and H.E. Russow. "Encapsulation of Heat-ofFusion Storage Materials." Proceedings of the Second Southeastern Conference on Application of Solar Energy. Baton Rouge, April 19-22, 1976, pp. 442-450.

25. Janz, George, J., Carolyn B. Allen, Joseph R. Downey, Jr., and P.D.T. Tumkins. Physical Properties Data Compilations Relevant to Energy Storage in Molten Salts: Eutectic Data. Part 1. National Bureau of Standards, NSRDS-NBS61, March 1978.

26. Golibersuch, D.C. et al. Cool Storage Assessment Study Prepared by the G. E. Company for the Electric Power Research Institute, EPRI, EPRI EM-468, May 1977.

27. Telkes, M., and E. Raymond. "Storing Solar Heat in Chemicals: A Report on the Dover House." Heating and Ventilating, Vol. $80,1949$.

28. Boer, K.W., J.H. Higgins, and J.K. O'Conner. Solar One, Two Year's Experience, Institute of Energy Conservation, University of Delaware.

29. Harold G. Lorsch. Latent Heat and Sensible Heat Storage for Solar Heating Systems. Report No. NSF/RANN/ 8E/012796/TR72/20, University of Pennsylvania, 1974.

30. Personal communication with John Kincel of the American Technological University, August $7 \mathrm{th}, 1978$.

31. Personal communication with SMC personnel.

32. Personal communication with Timothy Johnson, Department of Architecture, Massachusetts Institute of Technology, July 1978 .

33. Johnson, T.E. "Lightweight Thermal Storage for Solar Heated Buildings." Solar Energy, Vol. 19, Nov. 6, 1977.

34. "Salt Shaker for Latent Heat Storage." Heating/Piping/ Air Conditioning, March 1978.

35. Herrick, C.S., and D.C. Golibersuch. Qualitative Behavior of a New Latent Heat Storage Device for Solar Heating/Cooling Systems, General Electric Report No. 77CR0006, March 1977. 
36. Botham, R.A., G.H. Jenkins, G.L. Ball, and I.O. Salyer. Form-Stable Crystalline Polymer Pellet for Thermal Energy Storage, Phase I. ORO/5159-10, Monsanto Research Co., July 1977.

37. Personal communications with R.D. Olson of Addison Products Corporation, August 1978.

38. Installation and Operating Instructions. Add-A-Sun Solar Heating System, Addison Products Co.

39. Hise, E.C., Moyers, J.C., and H.C. Fischer, Design Report for the ACES Demonstration House, ORN $\bar{L} / \mathrm{CON}-1$, October, 1976.

40. Hise, E.C. Performance Report for the ACES Demonstration House, August 1976 through August 1977. ORNL/CON-19, March 1978.

41. Calmac Manufacturing Corporation, Sodium Sulfate Solid/ Solid Phase Change Thermal Energy Storage Module. Final Report for NASA Contract NA53-20986, June 1978.

42. T.T. Bramlette, R. W. Mar. Fiscal Year 1978 Annual Operating Plan for the Thermolchemical Energy Storage and Transport Program of the National Themal Energy Storage Program, Sandia Laboratories, Livermore, California, May 1978.

43. Boeing Engineering and Construction. Advanced Thermal Energy Storage Concept Definition Study for Solar Brayton Power Plants. Volume I, Final Technical Report, July 1 December 21, 1976. U.S. Department of Energy.

44. R. Schulten, et al. "The Concept of Nuclear Hydrogen Production and Progress of Work in the Nuclear Research Center Juelich." Paper presented at the 1st World Hydrogen Conference, Miami Beach, Fla., March 1-3, 1976.

45. Jon B. Pangborn. "Hydrogen Energy Technology-Update 1976." in Energy Technology III, Proceedings of the Third Energy Technology Conference, Washington, D.C. 1976.

46. E.W. Schmidt and P.A. Lowe. "Thermochemical Energy Storage Systems.", Proceedings of the Eleventh Intersociety Energy Conversion Engineering Conference 1 , American Institute of Chemical Engineers, New York, 1976 . 
47. Environment and Energy Conservation Division, The Aerospace Corporation. Characterization and Applications Analysis of Energy Storage System. Prepared for National Science Foundation, Aerospace Report No. ATR-77(7538) -1, El Segundo, California, December 1977.

48. P. Offenhartz. "Methanal-Based Single-Instrate Heat Pump for Solar Thermal Storage." Proceedings of Second Annual Thermal Energy Storage, Contractors Information Exchange Meeting, Oak Ridge National Laboratory, September 29-30, 1977, Gatlinburg, Tennessee.

49. L. Greiner. The Chemical Heat Pump: A Simple Means tó Conserve Energy. Final Report, September 1, 1976 to February 28, 1977, submitted to ERDA by Chemical Energy Specialists, Costa Mesa, California.

50. D.D. Huxtable, D.R. Doole. "Thermal Energy Storage by the Sulfuric Acid-Water System" Conference of American Section of the International Solar Energy Society and the Solar Energy Society of Canada, Inc., Volume 8, August 15-20, 1976.

51. F.A. Jaeger. "Thermochemical Energy Storage Systems" Proceedings of Second Annual Thermal Energy Storage, Contractors ' Information Exchange Meeting, Oak Ridge National Laboratory, September 29-30, 1977, Gatlinburg, Tennessee.

52. Hooper, F.C. "Annual Storage." Solar Age, Vol. 3, No. 4, April 1978.

53. Environment and Energy Conservation Division, Characterization and Applications Analysis of Energy Storage Systems, The Aerospace Corporation, El Segundo, California, Aerospace Report No. ATR-77(7538)-1, December 1977, pp. 2-80.

54. ASHRAE Standard 94-77, Method of Testing Thermal Storage Devices Based on Thermal Performance, The American Society of Heating, Refrigerating, and Air-Conditioning Engineers, Inc., 1977.

55. Hooper, F.C., et al., "Solar Space Heating Systems Using Annual Heat Storage," Progress report for period July 1December 30,1977 , Department of Mechanical Engineering, University of Toronto, Toronto, Canada.

56. Ruegg, R.T., Solar Heating and Cooling In Buildings: Methods of Economic Evaluation, National Bureau of Standards, U.S. Department of Commerce, NBSIR 75-712, July 1975 . 
57. Rabl A., and C.E. Nielsen. "Solar Ponds for Space Heating." Solar Energy, April 1973, pp. 1-12.

58. Short, T.H., P.C. Badge, and W.L. Roller. A Solar Pond for Heating Greenhouses and Rural Residences.

59. Catalog on Solar Energy Heating and Cooling Products, Energy Research and Development Administration, ERDA75 , October 1975 .

60. Solar Furnace System Design Guide, Solar Components Division, Kalwall Corporation, Manchester, NH, 1978.

61. American Society of Mechanical Engineer, ASME Boiler and Pressure Vessel Code. Section III. "Rules for Construction of Nuclear Vessels." ASME, New York, 1965 .

62. Bliss, R.W., "Atmospheric Radiation Near the Surface of the Earth," Solar Energy, Vol. 5, No. 3, 1961, p. 103 .

63. Yellott, J.I., "Early Tests of the Skytherm System," Passive Solar Heating and Cooling Conference and Workshop Proceedings, May 18-19, 1976, LA-6637-C NTIS.

64. Carrier, W.A., Mark's Mechanical Engineers' Handbook. 3rd Edition 1942, p. 1664, McGraw-Hill, New York.

65. Niles, P.W.B., "Modeling the Atascadero House, Passive Solar Heating and Cooling Conference and Workshop Proceedings, May 18-19, 1976. LA-6637-CNTIS, p. 183.

66. Proceedings of Symposium on Use of Solar Energy for Poultry and Livestock Production, Auburn University, November 9-10, 1976.

67. Troeger, J.M., and J.L. Butler. "Solar Drying of Peanuts in Georgia". Proceedings: Solar Crop Drying Conference, June 30,1977 , NCSU.

68. Rocket Research Company, "Sulfuric Acid-Water Chemical Heat Pump/Energy Storage System Demonstration" to be presented at ASME, 1978 Annual Meeting, Energy Storage Session.

69. Kahan, W., and Estes R.C., "The Economic Constraints on Solar Energy, Heat Pump, and Solar Assisted Heat Pump Systems," Proceedings of the 1978 Annual Meeting, American section of the International Solar Energy Society, Inc. Volume 2.1, pp. 288-292, August 28-31, 1978. 
APPENDIX A

DATA SHEETS FOR SELECTED

STORAGE UNITS 


\begin{tabular}{|c|c|}
\hline \multicolumn{2}{|c|}{ THERMAL ENERGY STORAGE UNIT DATA SHEET \#I } \\
\hline \multirow{3}{*}{$\begin{array}{l}\text { STORAGE UNIT } \frac{\text { Sun-Lite }}{\text { NAME: }} \\
\text { MANUFACTURER: } \frac{\text { Storage Tubes }}{\text { Kalwall Solar }} \\
\text { (or DEVELOPER) Components Division } \\
\text { STAGE OF } \\
\text { DEVELOPMENT: Commercially AVailable }\end{array}$} & \multirow{3}{*}{ 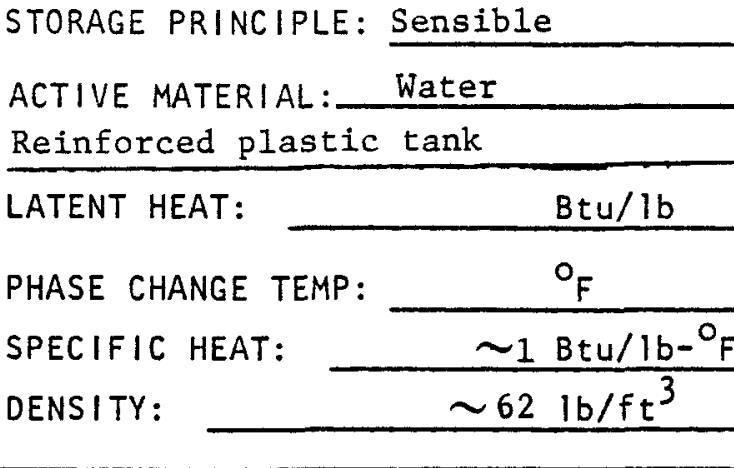 } \\
\hline & \\
\hline & \\
\hline $\begin{array}{l}\text { COMPONENT } \\
\text { SIZE: } 17.66 \mathrm{ft}^{3}(1.5 \mathrm{ft} \text {. dia. by } 10 \\
\text { COMPONENT ENERGY ft. long) } \\
\text { DENSITY: } 43,797 \text { Btu } \Delta \mathrm{T}=40^{\circ} \mathrm{F}\end{array}$ & $\begin{array}{l}\text { SYSTEM LIFE: } 20 \text { years estimated } \\
\text { CYCLE EFFICIENCY: } \%\end{array}$ \\
\hline $\begin{array}{l}\text { UNIT SIZE: } \\
\text { UNIT ENERGY } \\
\text { CAPACITY: } \quad- \\
\end{array}$ & SUGGESTED CYCLE TIME(S): Daily \\
\hline COMPONENT COST: & \multirow[t]{2}{*}{$\begin{array}{r}\text { STAND-BY LOSSES: } \frac{(3)}{{ }^{\circ} \mathrm{F}} \\
\end{array}$} \\
\hline $\begin{array}{l}\text { STORAGE UNIT COST: } \\
\text { MATERIAL COST/10 }\end{array}$ & \\
\hline $\begin{array}{l}\text { HEAT TRANSFER MECHANISM: } \\
\text { IN: Direct Passive Absorption }\end{array}$ & $\begin{array}{l}\text { SUGGESTED INTERFACE: } \\
\text { Passive }\end{array}$ \\
\hline OUT: Forced Air & ANCILLARY EQUIPMENT Fans or Blowers \\
\hline \multicolumn{2}{|l|}{ HEAT TRANSFER RATE: } \\
\hline DISCHARGE: $2,100 \quad B$ Btu/h & \\
\hline $\begin{array}{l}\text { COMMENTS: } \\
\text { (1) Under an insolation of } 1725 \mathrm{~B} \\
\text { will rise from } 65^{\circ} \mathrm{F} \text { to about } \\
\text { (2) } \Delta \mathrm{T}=30^{\circ} \mathrm{F} \text { and air flow } 500 \mathrm{ft} \\
\text { (3) A function of the insulation }\end{array}$ & $\begin{array}{l}\text { q. ft. the temperature in this tube } \\
\text { in a full day. } \\
\text { he enclosing container. }\end{array}$ \\
\hline
\end{tabular}




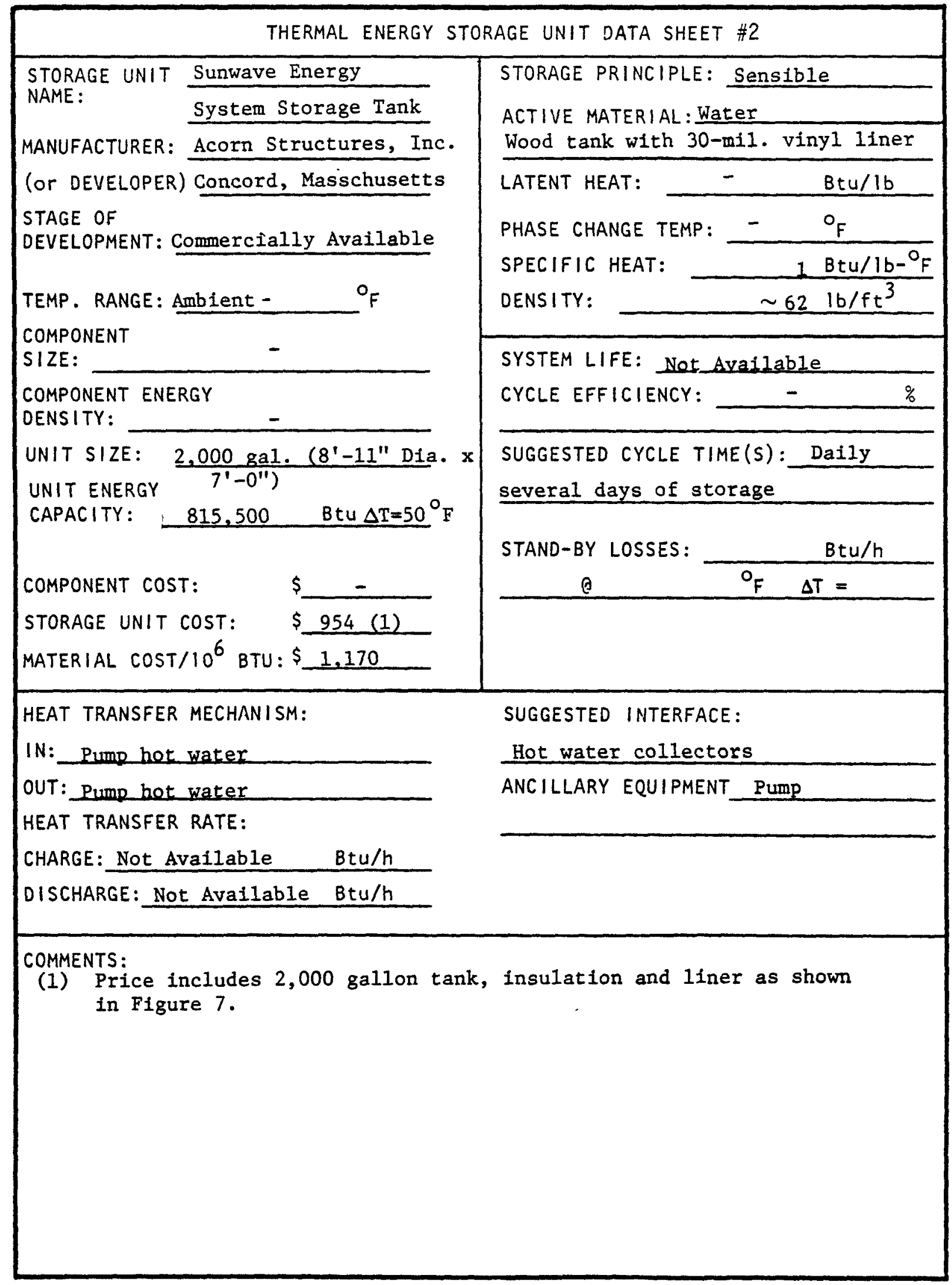


THERMAL ENERGY STORAGE UNIT DATA SHEET \#3

STORAGE UNIT Solatherm

NAME:

Solar Storage Tank

MANUFACTURER: Solatherm Corporation

(or DEVELOPER)

STAGE OF

DEVELOPMENT: Commercially Available

TEMP. RANGE: Ambient- $210^{\circ} \mathrm{F}$

COMPONENT

SIZE:

COMPONENT ENERGY

DENSITY:

UNIT SIZE: $\quad 2,000$ gallons $\left(10^{\prime}-4^{\prime \prime} \mathrm{x}\right.$

UNIT ENERGY $\frac{2,000 \text { gallons }}{\left.7^{\prime}-2^{\prime \prime} \times 5^{\prime}-4^{\prime \prime}\right)}$

CAPACITY: $\quad 1.6 \times 10^{6}$ BtU $\triangle \mathrm{T}=100^{\circ} \mathrm{F}$

$\begin{array}{ll}\text { COMPONENT COST: } & \$ \frac{1}{-} \\ \text { STORAGE UNIT COST: } & \$ 1,695(3)\end{array}$ MATERIAL COST/10 $10^{6}$ BTU: $\$ 2,118 \triangle T=50^{\circ} \mathrm{F}$

HEAT TRANSFER MECHANISM:

Fluid heat exchanger or

IN: water removal

Fluid heat exchanger or water

OUT: removal

HEAT TRANSFER RATE:

$\begin{array}{lll}\text { CHARGE: } & \text { N/A } & \text { Btu/h } \\ \text { DISCHARGE: } & \text { N/A } & \text { Btu/h }\end{array}$

STORAGE PRINCIPLE: Sensible

ACTIVE MATERIAL: Water

Reinforced concrete tank with R-I8

foam insulation and $30-45 \mathrm{mil}$ re-

inforced polyester liner

LATENT HEAT:

PHASE CHANGE TEMP:

SPECIFIC HEAT:

DENSITY:

$-s t u / 1 b$

$\mathrm{F}$

-1 Btu/1b- ${ }^{\circ} F$ $\sim 62 \mathrm{lb} / \mathrm{ft}^{3}$

SYSTEM LIFE:

10 years (1)

CYCLE EFFICIENCY:

(2) $\%$

SUGGESTED CYCLE TIME(S): Daily, several days

STAND-BY LOSSES: $\frac{(2) \quad B t u / h}{O_{F} \Delta T=}$

SUGGESTED INTERFACE:

Hat water collectors

ANCILLARY EQUIPMENT PumPs to

circulate water out of storage

COMMENTS:

(1) 10 years claimed for innerliner which can be replaced for the cost of the liner and installation labor.

(2) A function of the insulation enclosing the tank.

(3) 2,000 gallon tank supplied with insulation, liner, fitting and heat exchanger as shown in Figure 8 . Price does not include delivery. 


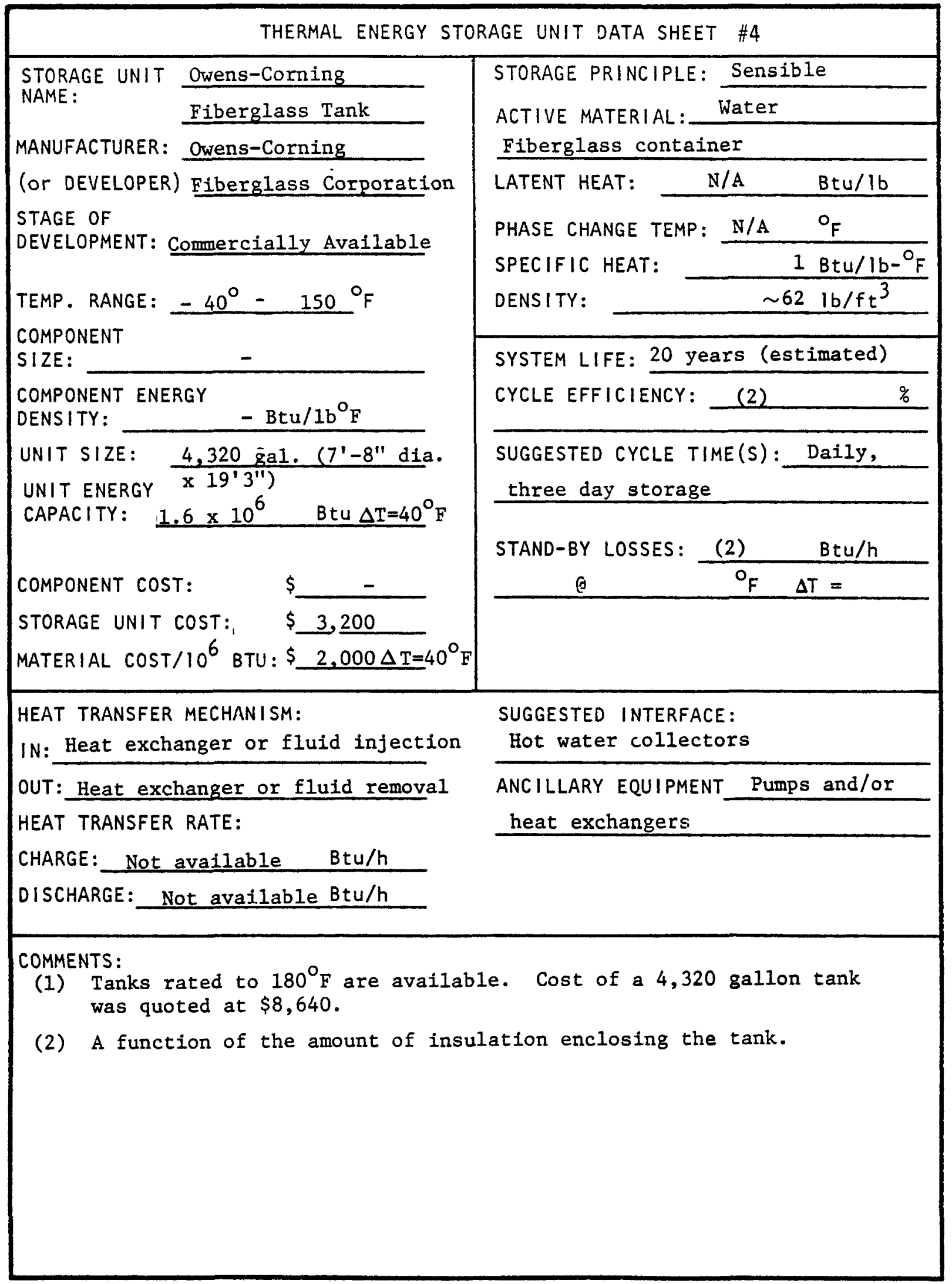




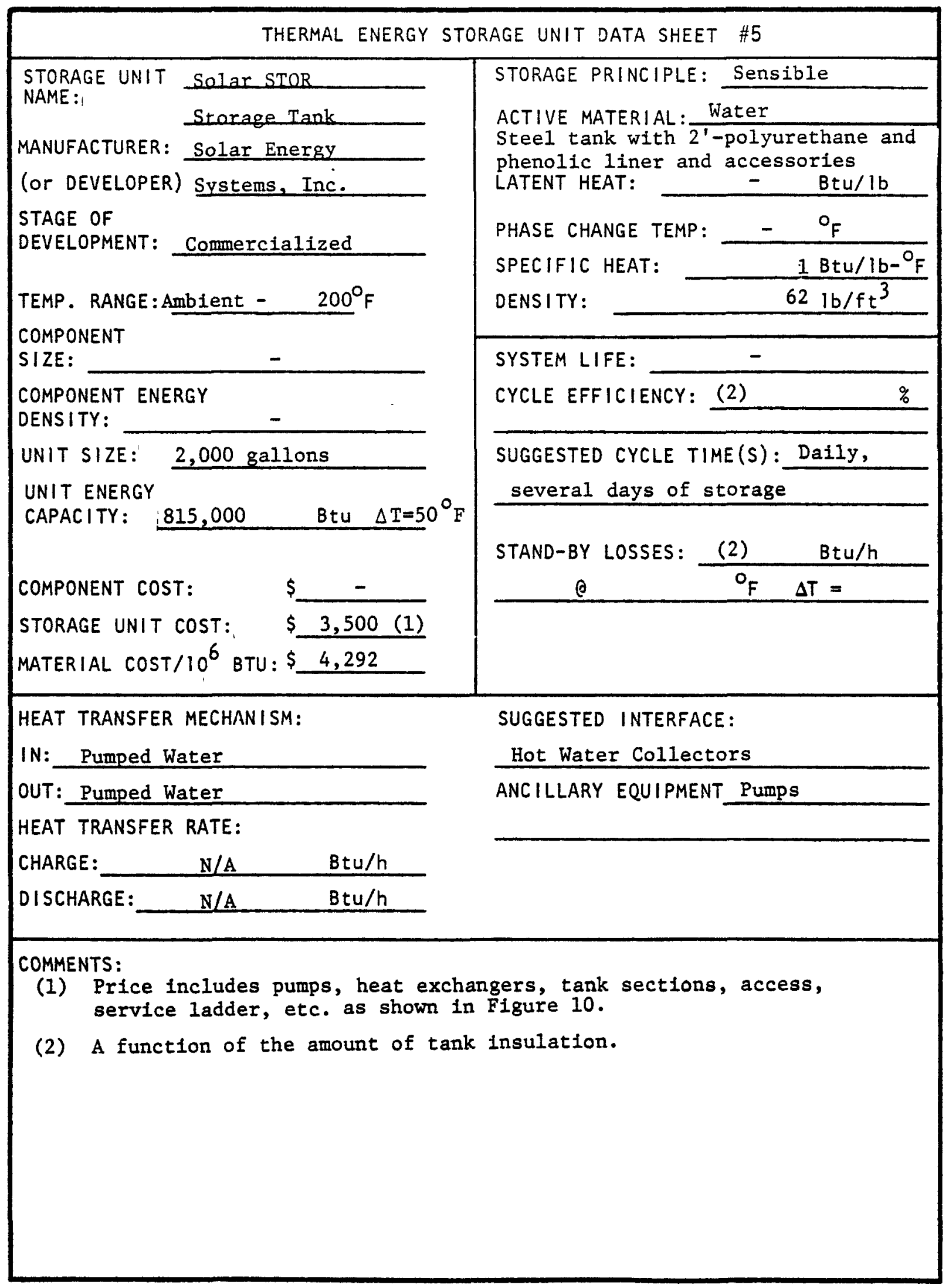




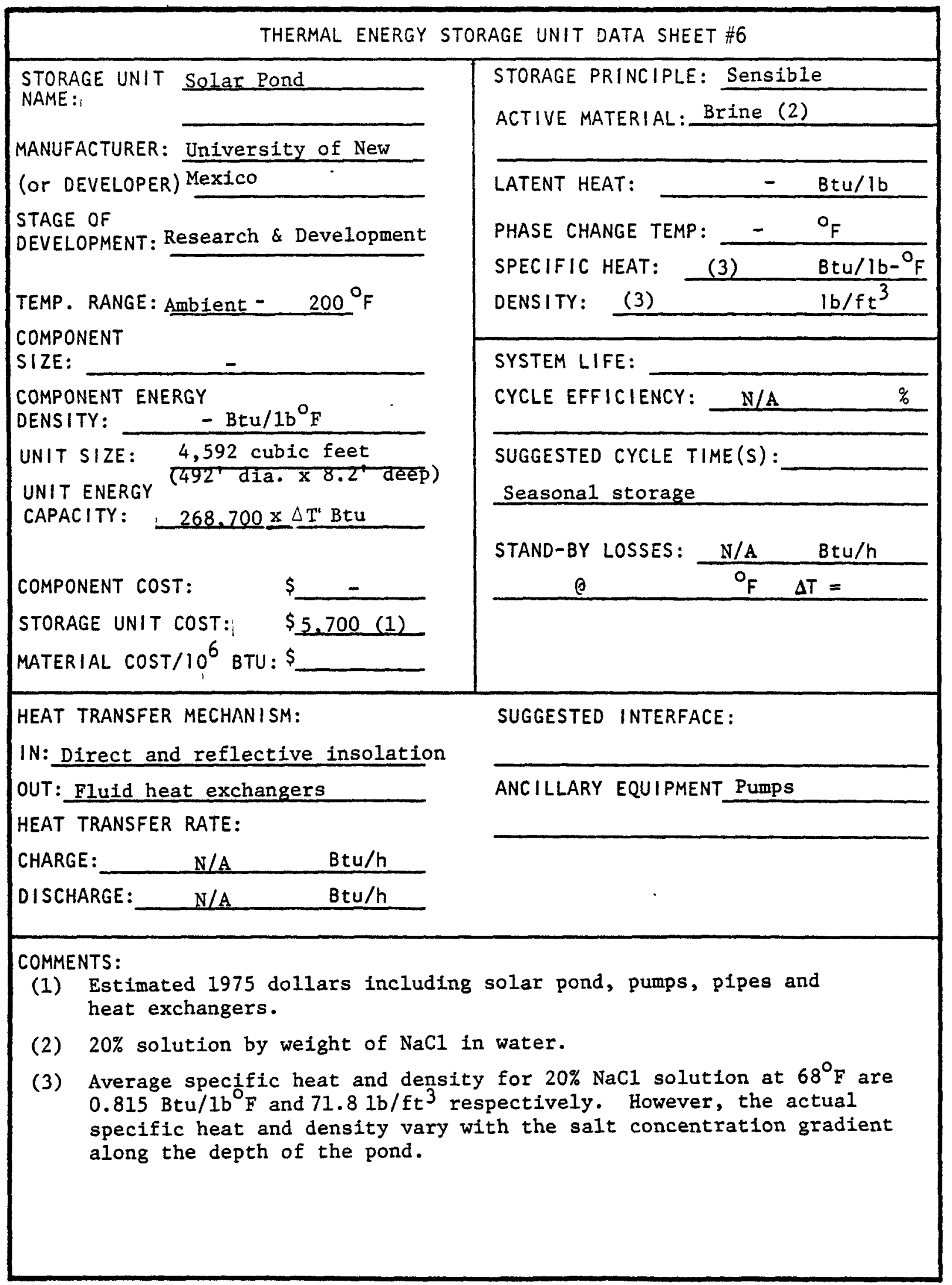


THERMAL ENERGY STORAGE UNIT DATA SHEET \#7

STORAGE UNIT Rock Storage NAME:

MANUFACTURER:

(Or DEVELOPER)

STAGE OF

DEVELOPMENT: Developed

TEMP. RANGE: $80^{\circ}-180^{\circ} \mathrm{F}$

COMPONENT

SIZE: $.75-1.25$ " Diameter rocks COMPONENT ENERGY

DENSITY: N/A

UNIT SIZE:

(1)

UNIT ENERGY

CAPACITY:

(1) Btu

COMPONENT COST:

$\$ 9.50-10.50 /$ ton

STORAGE UNIT COST:

$\$$ (1)

MATERIAL COST/10 6 BTU: $\$ 500$ (3)

HEAT TRANSFER MECHANISM:

IN:

Air

OUT: Air

HEAT TRANSFER RATE:

(1)

(1)

$\mathrm{Btu} / \mathrm{h}$

CHARGE:

DISCHARGE :
STORAGE PRINCIPLE: Sensible Heat

ACTIVE MATERIAL: RockS

LATENT HEAT:

N/A

$\mathrm{Btu} / \mathrm{Ib}$

PHASE CHANGE TEMP: N/A ${ }^{\circ} \mathrm{F}$

SPECIFIC HEAT: .195.-.22 Btu/16- ${ }^{\circ} \mathrm{F}$

DENSITY:

$100-125$

(4)

$1 b / f t^{3}$

SYSTEM LIFE: 50 years +

CYCLE EFFICIENCY: $100 \%$

SUGGESTED CYCLE TIME(S): Diurnal

STAND - BY LOSSES :

(1) Btu/h

(2)

e

${ }^{\circ}{ }_{F} \quad \Delta T=$

SUGGESTED INTERFACE :

Forced Air System or Heat Pump

ANCILLARY EQUIPMENT Insulated Bin,

Ducts, and Air Handling Unit

COMMENTS:

(1) Design Specific

(2) Delivered Price

(3) $50^{\circ} \mathrm{F}$ swing

(4) .75 - 1.50" Diameter 
THERMAL ENERGY STORAGE UNIT DATA SHEET \#8

STORAGE UNIT Trombe WaII

NAME:

MANUFACTURER: Miche1, Jacques and

(or DEVELOPER) Felix Trombe

STAGE OF

DEVELOPMENT: Developed

TEMP. RANGE : Ambient $-180^{\circ} \mathrm{F}$

COMPONENT

SIZE: 8-10" thick concrete wall COMPONENT ENERGY

DENSITY: $240 \mathrm{BLU} / \mathrm{ft}^{2}$ of surface (1)

UNIT SIZE: (2)

UNIT ENERGY

CAPACITY:

(2)

Btu

COMPONENT COST: $\$ 75 /$ cubic yard

STORAGE UNIT COST:

MATERIAL COST/10 6 BTU: $\$ 8,680$
STORAGE PRINCIPLE: Therma1 Mass

ACTIVE MATERIAL:COncrete Wa11

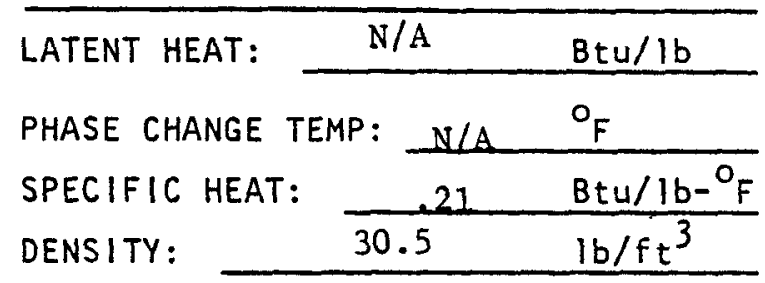

SYSTEM LIFE: $50^{+}$years

CYCLE EFFICIENCY:

100

SUGGESTED CYCLE TIME(S): Daily

STAND-BY LOSSES :

(2) Btu/h

a

${ }^{\circ} \mathrm{F} \quad \Delta T=$

SUGGESTED INTERFACE :

ANCILLARY EQUIPMENT Glass Wall

HEAT TRANSFER MECHANISM:

IN: Direct Gain (Radiation)

OUT: Thermosiphoning and Radiation

HEAT TRANSFER RATE:

CHARGE :

$\mathrm{Btu} / \mathrm{h}$

DISCHARGE:

(2)

Btu/h

COMMENTS:

(1) Cost of concrete in place for a $9^{\prime \prime}$ thickness and $50^{\circ} \mathrm{F}$ temperature swing.

(2) Design specific. 
THERMAL ENERGY STORAGE UNIT DATA SHEET \#9

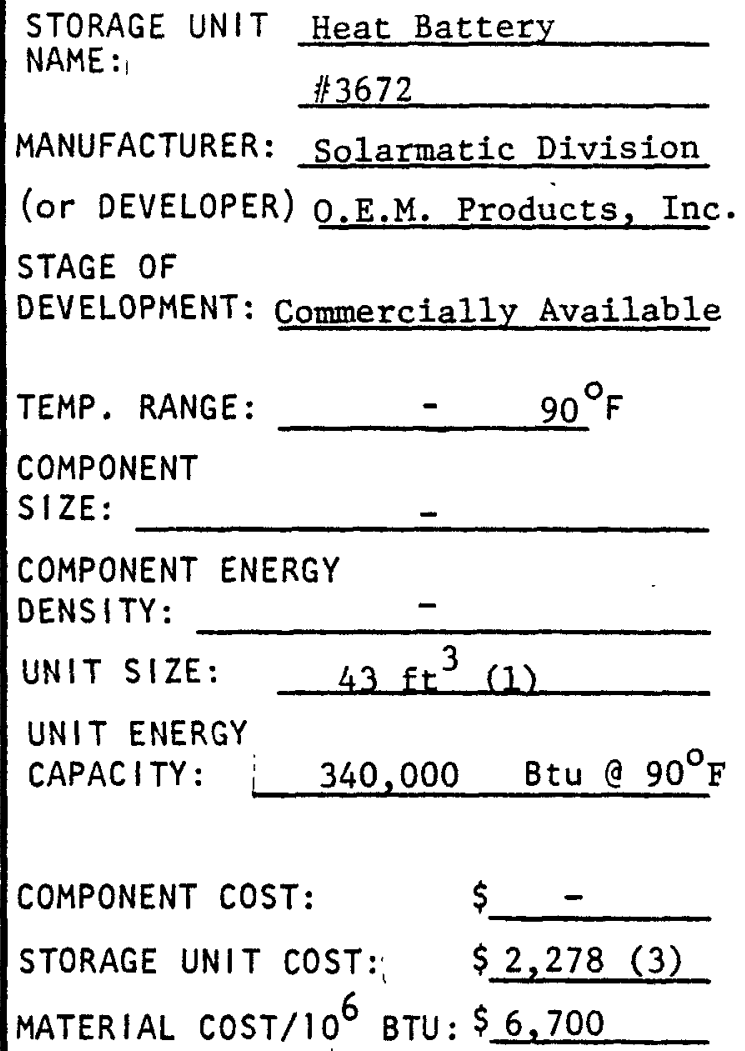

STORAGE PRINCIPLE: Phase-Change

ACTIVE MATERIAL: Glaubers Salt

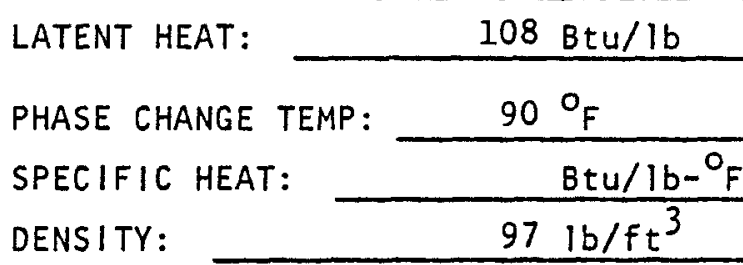

SYSTEM LIFE: 20 years claimed

CYCLE EFFICIENCY: $\%$

SUGGESTED CYCLE TIME(S): Daily, several days

STAND-BY LOSSES : $\mathrm{Btu} / \mathrm{h}$ ${ }_{F} \quad \Delta T=$

COMMENTS:

(1) The system contains $34 \mathrm{ft}^{3}$ of Glaubers Salt. Models with 23,86 , 124 and $173 \mathrm{ft}^{3}$ are available.

(2) The system is supplied with a heat exchanger and an immersible type pump for circulating the working oil through the Glaubers Salt.

(3) Price includes ancillary equipment as shown in Figure 13. 


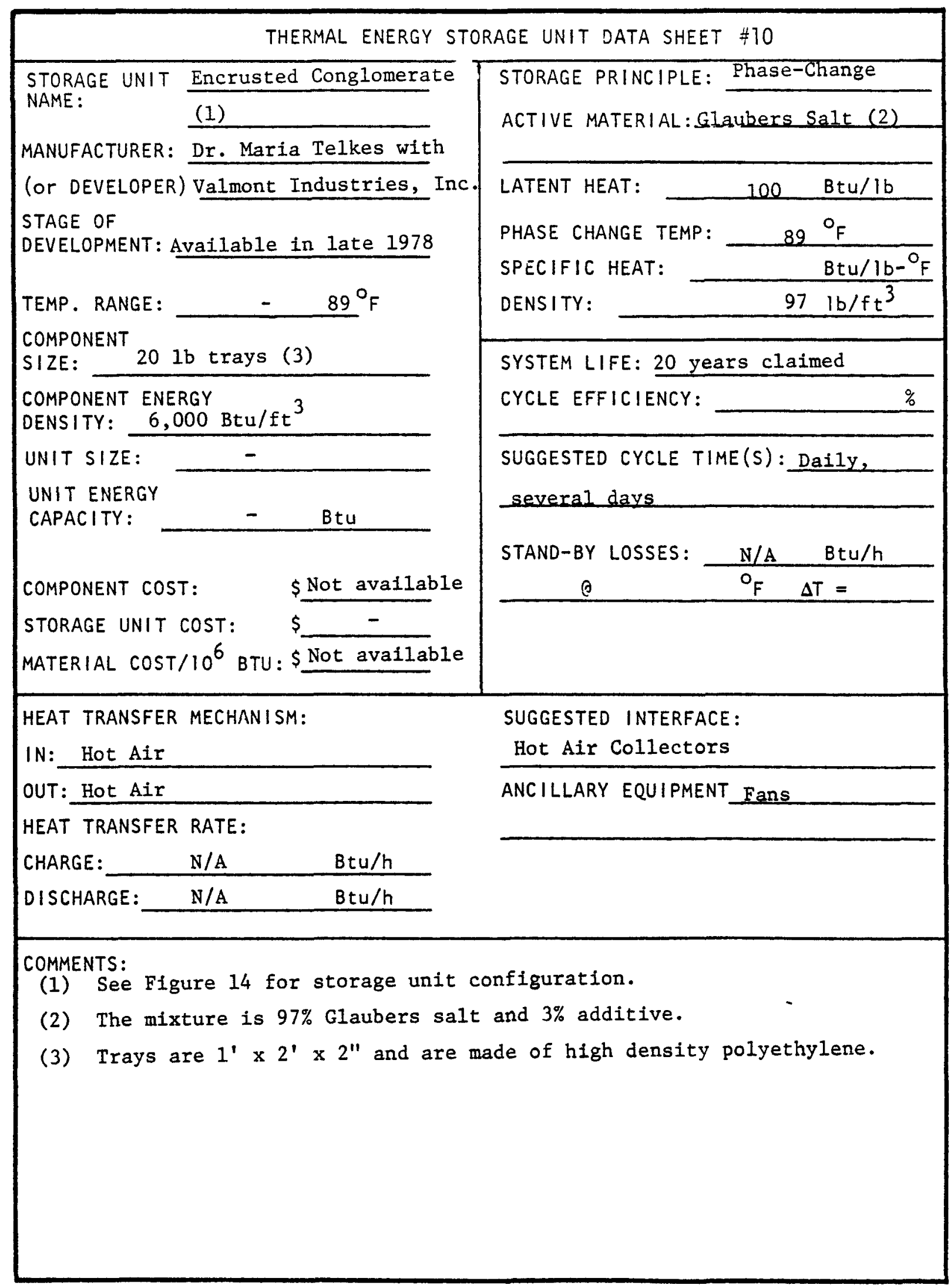




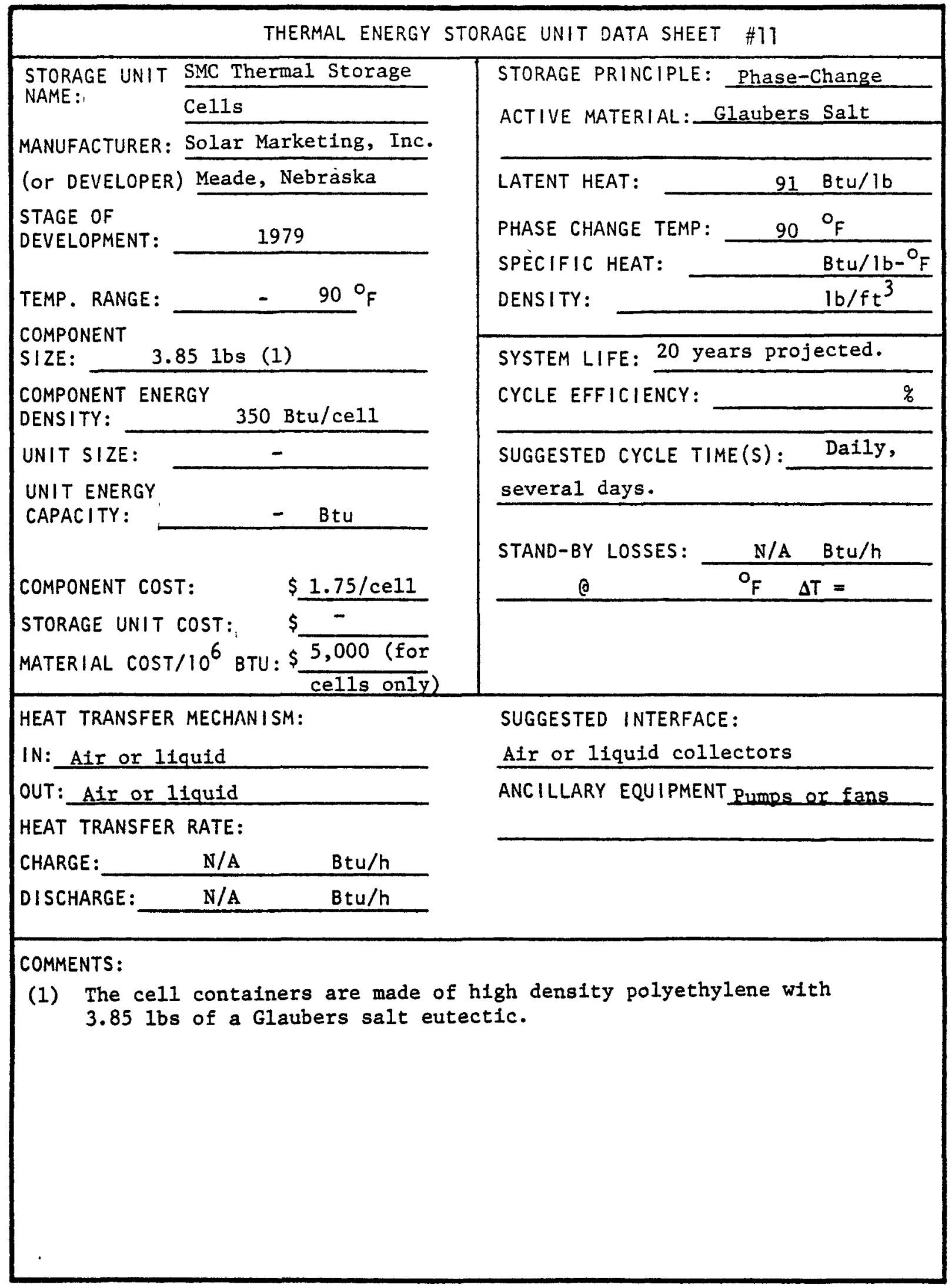


THERMAL ENERGY STORAGE UNIT DATA SHEET \#12

STORAGE UNIT SOL-AR-TILE

NAME :

MANUFACTURER: Architectural

(or DEVELOPER) Research Corporation

STAGE OF

DEVELOPMENT: Commercially Available

TEMP. RANGE: $65-75{ }^{\circ} \mathrm{F}$

COMPONENT

SIZE: $2^{\prime} \times 2^{\prime} \times 1-1 / 4^{\prime \prime}$ tile (2)

COMPONENT ENERGY

DENSITY:

$\mathrm{N} / \mathrm{A}$

UNIT SIZE:

UNIT ENERGY

CAPACITY:

Btu

COMPONENT COST:

$\$ \underline{3-3.50 / \text { tile }}$

STORAGE UNIT COST: $\$$

MATERIAL COST/10 $0^{6}$ BTU: $\$ 3400$.
STORAGE PRINCIPLE: Phase-change

ACTIVE MATERIAL. Glaubers Salt (I)

Polyester concrete shell with water pronf membrames (2)

LATENT HEAT:

33

Btu/lb

PHASE CHANGE TEMP:

SPECIFIC HEAT:

DENSITY:

$\frac{73^{\circ} \mathrm{F}}{-\quad B t u / 1 \mathrm{~b}-{ }^{\circ} \mathrm{F}}$

SYSTEM LIFE: 2,600 cycles +

CYCLE EFFICIENCY:

$\%$

SUGGESTED CYCLE TIME(S): Diurna1

STAND-BY LOSSES :

a

${ }^{\circ} \quad \Delta T=$
HEAT TRANSFER MECHANISM:

IN: Direct (or reflected) insolation

OUT: Radiation convection

HEAT TRANSFER RATE:

CHARGE: Typically 17

DISCHARGE:

17

17

$\mathrm{Btu} / \mathrm{h}$

Btu/h

COMMENTS:

(1) A Eutectic of Glaubers Salt.

(2) See Figure 15 for details.

SUGGESTED INTERFACE :

Passive

ANCILLARY EQUIPMENT None 
THERMAL ENERGY STORAGE UNIT DATA SHEET \#13

\begin{tabular}{|c|c|}
\hline STORAGE UNIT Cross Tinked HDPF & STORAGE PRINCIPLE:Phase-Change \\
\hline NAME: $\quad$ Prototype Unit & ACTIVE MATERIAL: HDPE (1) - 60 gallon \\
\hline MANUFACTURER: Monsanto Research & $\begin{array}{l}\text { pressurized container, material not } \\
\text { available }\end{array}$ \\
\hline (or DEVELOPER) Corporation & LATENT HEAT: $\quad 83 \mathrm{Btu} / \mathrm{Ib}$ \\
\hline STAGE OF & PHASE CHANGE TEMP: \\
\hline 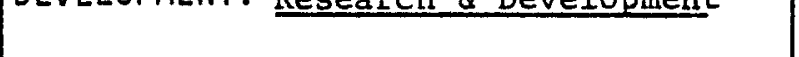 & SPECIFIC HEAT: \\
\hline TEMP. RANGE: & $-\quad \mathrm{b} / \mathrm{ft}^{3}$ \\
\hline $\begin{array}{l}\text { COMPONENT } \\
\text { SIZE: }\end{array}$ & SYSTEM LIFE: $1000+$ cycles \\
\hline $\begin{array}{l}\text { COMPONENT ENERGY } \\
\text { DENSITY: }\end{array}$ & CYCLE EFFICIENCY: \\
\hline UNIT SIZE: 60 gallon, 240 lbs & SUGGESTED CYCLE TIME(S): \\
\hline $\begin{array}{l}\text { UNIT ENERGY } \\
\text { CAPACITY: } \quad 29,400 \text { BtU } \\
\end{array}$ & \\
\hline & STAND-BY LOSSES: \\
\hline COMPONENT COST: & 0 \\
\hline $\begin{array}{l}\text { STORAGE UNIT COST: } \$ \frac{\text { N/A }}{\text { MATERIAL COST/10 }} \text { BTU: } \$ \text { N/A } \\
\text { M }\end{array}$ & \\
\hline $\begin{array}{l}\text { HEAT TRANSFER MECHANISM: } \\
\text { IN: Direct air or fluid heat transfer }\end{array}$ & SUGGESTED INTERFACE: \\
\hline $\begin{array}{l}\text { OUT: Direct air or fluid heat transfer } \\
\text { HEAT TRANSFER RATE: }\end{array}$ & ANCILLARY EQUIPMENT \\
\hline CHARGE: & \\
\hline DISCHARGE: & \\
\hline
\end{tabular}

COMMENTS:

(1) Silane-grafted/cross-linked high density polyethylene pellets.

(2) It is estimated that the PCM could be produced by processing in a polyethylene plant for a projected price near $26 \mathrm{c} / 1 \mathrm{~b}$. 
THERMAL ENERGY STORAGE UNIT DATA SHEET \#14

STORAGE UNIT Add-A-SUn NAME : Storage Chamber

MANUFACTURER: Addison Products Co. (or DEVELOPER) Addison, MI

STAGE OF

DEVELOPMENT: Commercially Available

TEMP. RANGE : $113-130^{\circ} F$

COMPONENT

SIZE: 1 gal. can (6.5 1bs of wax)

COMPONENT ENERGY

DENSITY: $520 \mathrm{Btu} /$ container (1atent UNIT SIZE: 840 lbs of storage

UNIT ENERGY

CAPACITY: $100,000-125,000$ Btu (2)

COMPONENT COST:

STORAGE UNIT COST: $\$ 1850$ (1)

MATERIAL COST/10 6 BTU: \$

HEAT TRANSFER MECHANISM:

IN: Forced Air

OUT: Forced Air

HEAT TRANSFER RATE:

\begin{tabular}{lll} 
CHARGE: & N/A & Btu/h \\
\hline DISCHARGE: & N/A & Btu/h \\
\hline
\end{tabular}

STORAGE PRINCIPLE: Phase-Change

ACT,IVE MATERIAL: Slack Wax

$6^{\prime} 6^{\prime} \times 3^{\prime}$ chamber with 4" polystyrene and one gallon cans for slack wax (3)

LATENT HEAT:

$80.1 \mathrm{Btu} / \mathrm{lb}$

PHASE CHANGE TEMP: $113-117^{\circ} \mathrm{F}$

SPECIFIC HEAT:

Btu/lb- ${ }^{\circ} F$

DENSITY: $\mathrm{ib} / \mathrm{ft}^{3}$

SYSTEM LIFE: More than 1500 cycles

CYCLE EFFICIENCY:

$\mathrm{N} / \mathrm{A}$ $\%$

SUGGESTED CYCLE TIME(S): Daily or several days of storage

STAND-BY LOSSES :

$\frac{\mathrm{N} / \mathrm{A} \quad \mathrm{Btu} / \mathrm{h}}{\mathrm{O}_{\mathrm{F}} \Delta \mathrm{T}=}$

\section{COMMENTS:}

(1) The storage unit cost includes 840 lbs of storage materials, a storage chamber with insulation and a blower fan.

(2) $140,000 \mathrm{Btu}$ is maximum while the lower figure above represents the effect of stratification in the storage chamber. Capacity includes sensible heat storage above $117^{\circ} \mathrm{F}$.

(3) For details see Figure 17 .

SUGGESTED INTERFACE:

Air Heating Collectors

ANCILLARY EQUIPMENT Blower fans

for air circulation 
THERMAL ENERGY STORAGE UNIT DATA SHEET \#15

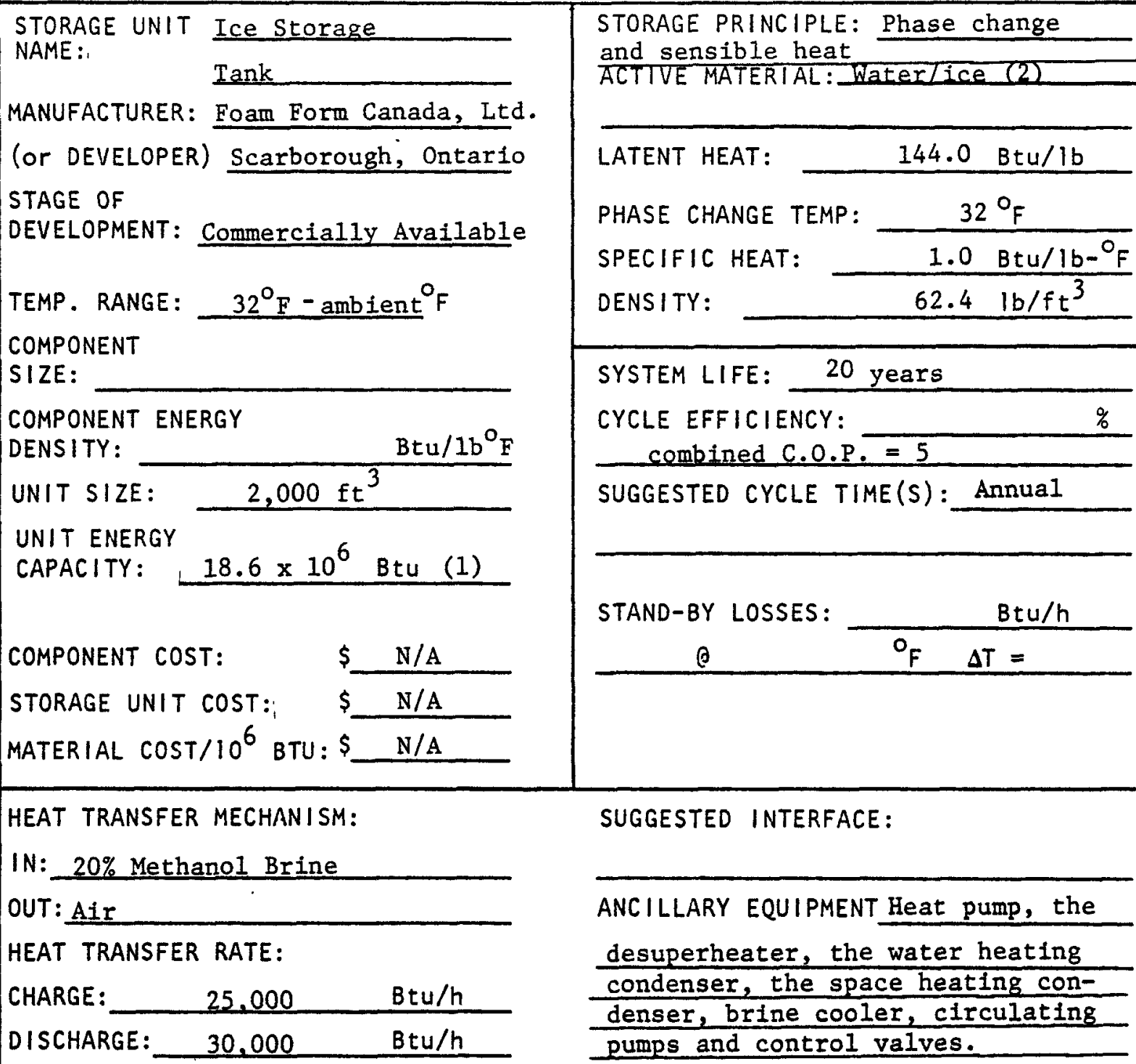

COMMENTS:

(1) Capacity includes latent heat of ice and the sensible heat of water from $32^{\circ} \mathrm{F}$ to $45^{\circ} \mathrm{F}$.

(2) For system schematic see Figure 18. 


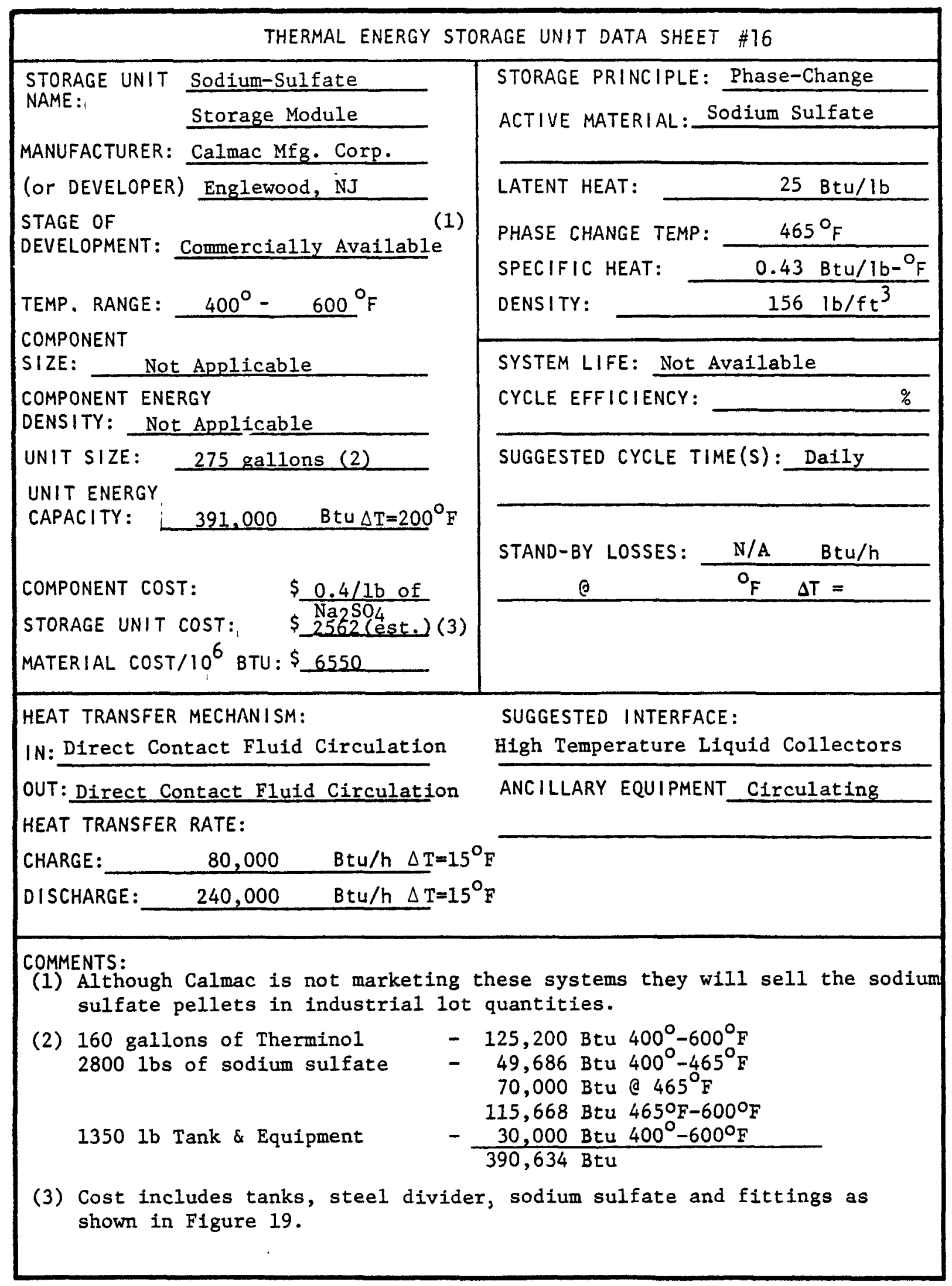




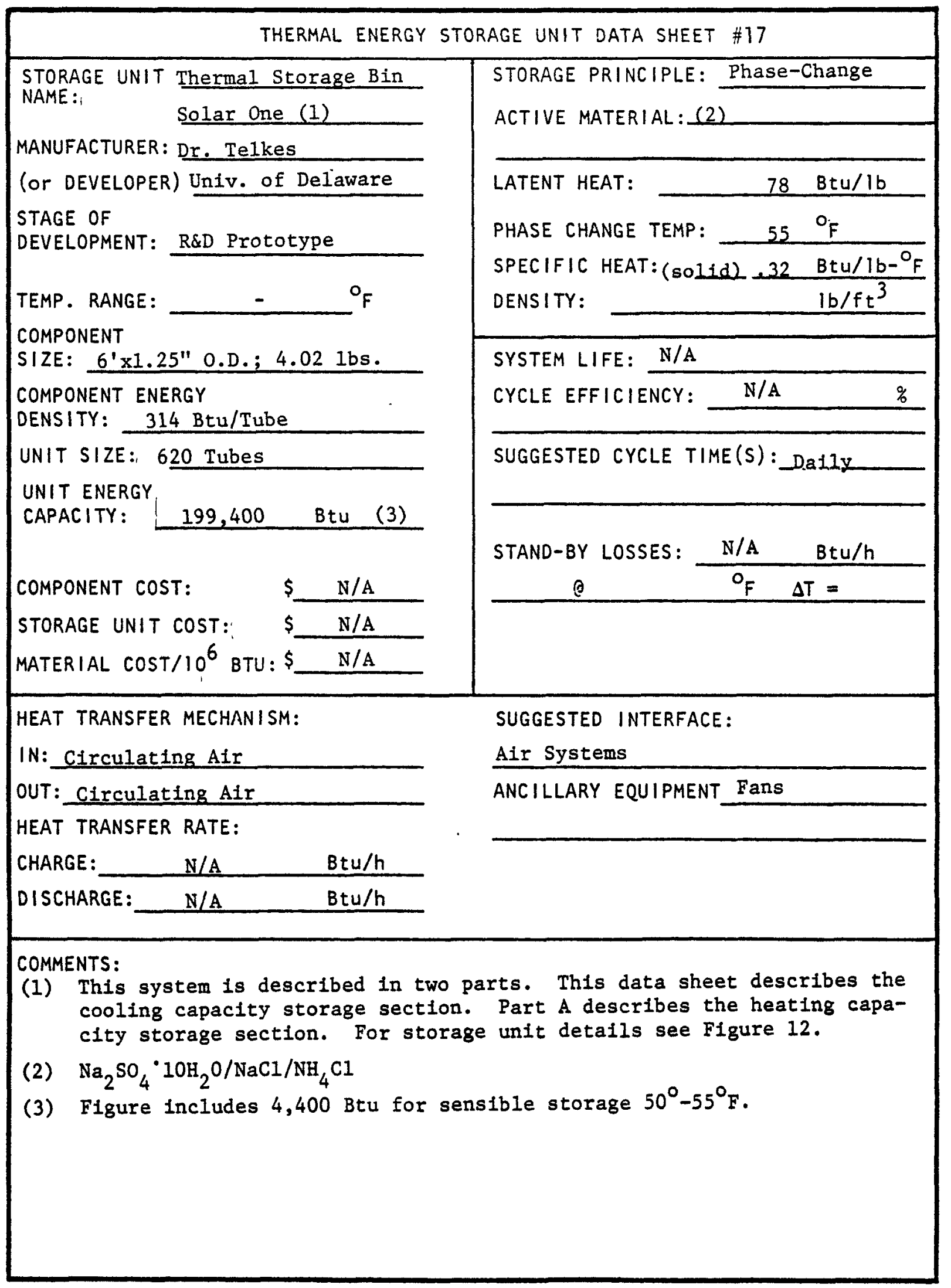




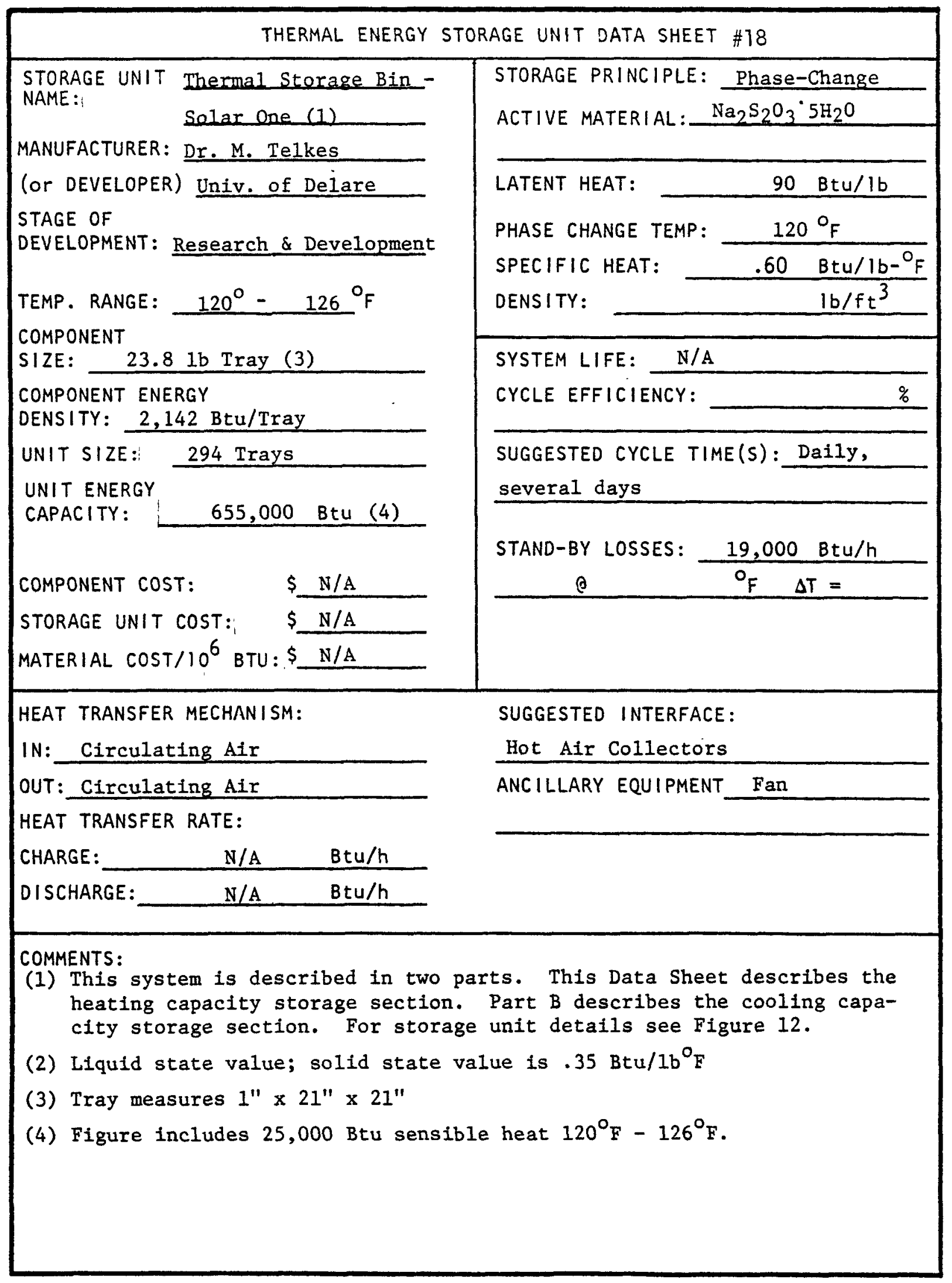


THERMAL ENERGY STORAGE UNIT DATA SHEET \#19

STORAGE UNIT Sodium Thiosulfate NAME :

MANUFACTURER: Pentahydrate Storage Module H.G. Lorsch

(or DEVELOPER) Univ. of Pennsylvania STAGE OF

DEVELOPMENT: R\&D prototype

TEMP. RANGE : $-119{ }^{\circ} \mathrm{F}$

COMPONENT

SIZE: $I^{\prime} \times 1^{\prime} \times 4^{\prime} ; 450$ lbs per module COMPONENT ENERGY

DENS ITY: $31,250 \mathrm{Btu} / \mathrm{module}$

UNIT SIZE: 16 modules

UNIT ENERGY

CAPACITY: 500,000 Btu

COMPONENT COST:
STORAGE UNIT COST:
MATERIAL COST $/ 10^{6}$ BTU: $\$ \frac{\text { N/A }}{\text { N/A }}$ N/A

HEAT TRANSFER MECHANISM:

IN: Liquid Heat Transfer

OUT: Liquid Heat Transfer

HEAT TRANSFER RATE:

\begin{tabular}{lll} 
CHARGE: & $\mathrm{N} / \mathrm{A}$ & $\mathrm{Btu} / \mathrm{h}$ \\
\hline DISCHARGE: & $\mathrm{N} / \mathrm{A}$ & $\mathrm{Btu} / \mathrm{h}$ \\
\hline
\end{tabular}

STORAGE PRINCIPLE: Phase-Change

ACTIVE MATERIAL: $\mathrm{Na}_{2} \mathrm{~S}_{3} \mathrm{O}_{3} \cdot 5 \mathrm{H}_{2} \mathrm{O}$

$16-1^{\prime} \times 1^{\prime} \times 4^{\prime}$ plastic modules

LATENT HEAT: $90 \mathrm{Btu} / \mathrm{lb}$

PHASE CHANGE TEMP:

$119^{\circ} \mathrm{F}$

SPECIFIC HEAT:

DENSITY:

- Btu/1b- ${ }^{\circ} F$ $103 \mathrm{lb} / \mathrm{ft}^{3}$

SYSTEM LIFE: N/A

CYCLE EFFICIENCY: N/A $\%$

SUGGESTED CYCLE TIME(S): Daily, several days of storage

STAND-BY LOSSES: N/A Btu/h Q ${ }^{\circ} F \quad \Delta T=$

SUGGESTED INTERFACE :

Liquid Collectors

ANC ILLARY EQUIPMENT PumPS

\section{COMMENTS:}


THERMAL ENERGY STORAGE UNIT DATA SHEET \#20

STORAGE UNIT P116 Paraffin Wax NAME :

Storage Module

MANUFACTURER: H.G. Lorsch

(or DEVELOPER)Univ. of Pennsylvania STAGE OF

DEVELOPMENT: R\&D Prototype

TEMP. RANGE :

COMPONENT

SIZE: $1^{\prime} \times 1^{\prime} \times 4^{\prime} 2^{\prime \prime}$ for a module

COMPONENT ENERGY

DENSITY: $12,500 \mathrm{Btu} / \mathrm{module}$

UNIT SIZE: 20 modules; 4' $\times 5^{\prime} \times 4^{\prime} 2^{\prime \prime}$

UNIT ENERGY

CAPACITY:

$250,000 \mathrm{Btu}$

COMPONENT COST:

$\$ \quad \mathrm{~N} / \mathrm{A}$

STORAGE UNIT COST: \$N/A

MATERIAL COST $/ 10^{6}$ BTU: $\$$ N/A

HEAT TRANSFER MECHANISM:

IN: Liquid Heat Transfer

OUT: Liquid Heat Transfer

HEAT TRANSFER RATE:

CHARGE:

N/A

DISCHARGE :

N/A

Btu/h

Btu/h
STORAGE PRINCIPLE: Phase-change

ACTIVE MATERIAL: Sunoco Paraffin 116

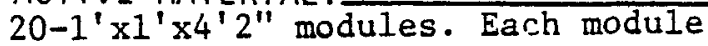

is stacked with $0.54^{\prime \prime} \times 12^{\prime \prime} \times 4^{\prime}-2$ " trays

LATENT HEAT: $90 \mathrm{Btu} / \mathrm{lb}$

PHASE CHANGE TEMP:

SPECIFIC HEAT:

$116^{\circ} \mathrm{F}$

DENSITY:

- Btu/1b- ${ }^{\circ} \mathrm{F}$

$49 \mathrm{lb} / \mathrm{ft}^{3}$

SYSTEM LIFE: N/A

CYCLE EFFICIENCY:

SUGGESTED CYCLE TIME(S): Daily

several days of storage

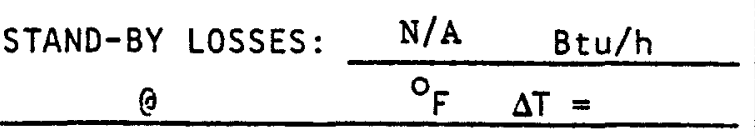

COMMENTS:

SUGGESTED INTERFACE:

Liquid Collectors

ANC ILLARY EQUIPMENT 


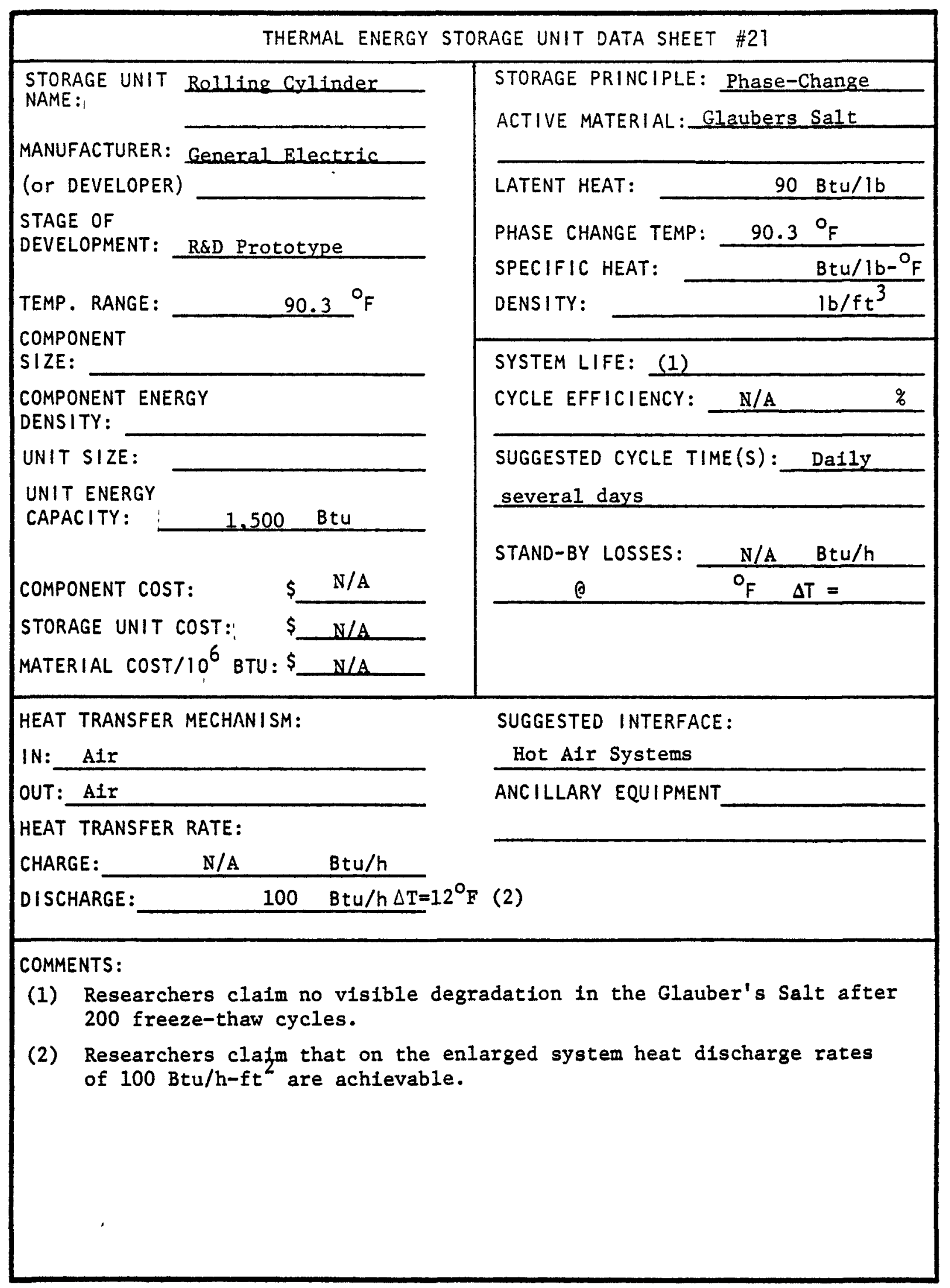


THERMAL ENERGY STORAGE UNIT DATA SHEET \#22

\begin{tabular}{|c|c|}
\hline \multirow{3}{*}{$\begin{array}{l}\text { STORAGE UNIT } \frac{\text { Sulfuric }}{\text { NAME: }} \\
\text { MANUFACTURER: Rocket Research Corp. } \\
\text { (or DEVELOPER) }\end{array}$} & $\begin{array}{l}\text { STORAGE PRINCIPLE: Chemical } \\
\text { ACTIVE MATERIAL: Sulfuric acid-water }\end{array}$ \\
\hline & \\
\hline & LATENT HEAT: \\
\hline $\begin{array}{l}\text { STAGE OF } \\
\text { DEVELOPMENT: Research \& Development } \\
\text { TEMP. RANGE : } 140-374^{\circ} \mathrm{F}\end{array}$ & $\begin{array}{l}\text { PHASE CHANGE TEMP: } \frac{-{ }^{\circ}}{\mathrm{B}} \\
\text { SPECIFIC HEAT: } \frac{\mathrm{Btu} / \mathrm{Ib}-{ }^{\circ} \mathrm{F}}{1 \mathrm{~b} / \mathrm{ft}^{3}} \\
\text { DENSITY: }\end{array}$ \\
\hline $\begin{array}{ll}\text { COMPONENT } & \text { Separator-14" Dia. x14'long } \\
\text { SIZE: } & \text { Tank Size-35,000 } \mathrm{ft}^{3} \\
\end{array}$ & SYSTEM LIFE: \\
\hline $\begin{array}{l}\text { COMPONENT ENERGY } \\
\text { DENSITY: }\end{array}$ & CYCLE EFFICIENCY: \\
\hline UNIT SIZE: & SUGGESTED CYCLE TIME(S): Seasona1 \\
\hline $\begin{array}{l}\text { UNIT ENERGY } \\
\text { CAPACITY: } \quad 181,440\end{array}$ & \\
\hline COMPONENT COST: & $\begin{array}{c}\text { STAND-BY LOSSES: } \\
0 \\
\end{array}$ \\
\hline $\begin{array}{l}\text { STORAGE UNIT COST: } \\
\text { MATERIAL COST } / 10^{6} \text { BTU: } \$ \frac{357,000}{\$ 2,000(4)}\end{array}$ & \\
\hline $\begin{array}{l}\text { HEAT TRANSFER MECHANISM: } \\
\text { IN: } 600^{\circ} \mathrm{F} \text { from collector to separator }\end{array}$ & $\begin{array}{l}\text { SUGGESTED INTERFACE: } \\
\text { Solar collectors, absorption system }\end{array}$ \\
\hline $\begin{array}{l}\text { OUT: From reactor to space or absorp- } \\
\text { HEAT TRANSFER RATE: }\end{array}$ & ANCILLARY EQUIPMENT Heat exchangers \\
\hline
\end{tabular}

CHARGE:

- Btu/h

DISCHARGE: $181,440 \quad$ Btu/h

COMMENTS:

(1) The concept of sulfuric acid-water system is not new. The toxicity and corrosiveness of sulfuric acid are the major obstacles to commercialization.

(2) The seasonal storage system was under study given a $20,000 \mathrm{ft}^{2}$ building located on the eastern seaboard of United States. Hardwares have not been built for testing.

(3) Schematic diagram and flow diagram are given in Figures $21 \mathrm{a}$ and $21 \mathrm{~b}$.

(4) The storage unit is assumed to discharge at the rate of 181,440 Btu for 24 hours per day. Cost is based on 1976 estimates including collectors, tanks, heat exchangers, piping, pumps, etc. 


\begin{tabular}{|c|c|}
\hline \multicolumn{2}{|c|}{ THERMAL ENERGY STORAGE UNIT DATA SHEET \#23 } \\
\hline \multirow{2}{*}{$\begin{array}{l}\text { STORAGE UNIT Magnesium Chloride } \\
\text { NAME: } \\
\text { MANUFACTURER: Chemical Energy } \\
\text { (or DEVELOPER) Specialists }\end{array}$} & $\begin{array}{l}\text { STORAGE PRINCIPLE: } \frac{\text { Chemical }}{\mathrm{MaCl}_{2} \cdot 2 \mathrm{H}_{2} \mathrm{O}} \\
\text { ACTIVE MATERIAL: }\end{array}$ \\
\hline & \multirow{2}{*}{\begin{tabular}{l} 
LATENT HEAT: \\
\cline { 2 - 2 } PHASE CHANGE TEMP: $\frac{\mathrm{Btu} / \mathrm{lb}}{{ }^{\circ} \mathrm{F}}$ \\
SPECIFIC HEAT: \\
DENSITY:
\end{tabular}} \\
\hline $\begin{array}{l}\text { STAGE OF } \\
\text { DEVELOPMENT: Research \& Development }\end{array}$ & \\
\hline $\begin{array}{l}\text { TEMP. RANGE: } \frac{30-180^{\circ} \mathrm{F}}{\text { COMPONENT }} \\
\text { SIZE: } \\
3^{\prime} \times 7^{\prime} \times 1^{\prime \prime}\end{array}$ & SYSTEM LIFE: Not available \\
\hline $\begin{array}{l}\text { COMPONENT ENERGY } \\
\text { DENSITY: }\end{array}$ & CYCLE EFFICIENCY: \\
\hline $\begin{array}{l}\text { UNIT ENERGY } \\
\text { CAPACITY: } \quad 1,000,000 \quad \text { Btu }\end{array}$ & $\begin{array}{l}\text { SUGGESTED CYCLE TIME(S): } \\
1 \mathrm{cycle} / \mathrm{day} \\
\end{array}$ \\
\hline \multirow[b]{2}{*}{ COMPONENT COST: $\quad \$ \quad \mathrm{~N} / \mathrm{A}$} & \multirow{2}{*}{ STAND-BY LOSSES: $\frac{B t u / h}{O_{F} \Delta T=}$} \\
\hline & \\
\hline \multicolumn{2}{|l|}{$\begin{array}{l}\text { STORAGE UNIT COST: } 1, \$ \frac{\mathrm{N} / \mathrm{A}}{\mathrm{N} / \mathrm{A}} \\
\text { MATERIAL COST/10 }\end{array}$} \\
\hline $\begin{array}{l}\text { HEAT TRANSFER MECHANISM: } \\
\text { IN: Forced air around vaporizer }\end{array}$ & SUGGESTED INTERFACE: \\
\hline \multirow{3}{*}{ 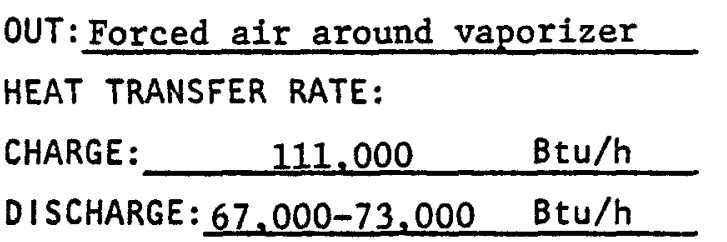 } & ANCILLARY EQUIPMENT__ Fan \\
\hline & \\
\hline & \\
\hline \multicolumn{2}{|c|}{$\begin{array}{l}\text { (1) Vaporizer operates between } 30-70^{\circ} \mathrm{F} \text {, absorber operates between } 140-18 \text {, } \\
\text { Temperature required for recharging is } 225^{\circ} \mathrm{F} \text { theoretically, however, } \\
280-300^{\circ} \mathrm{F} \text { is more adequate in experiments. } \\
\text { (2) The system is still in the preliminary studying stage. Only several } \\
\text { cycles have been tested. } \\
\text { (3) Vapor pressure - temperature relationship is shown in Figure } 22 \text {. } \\
\text { (4) Hardware configurations are shown in Figure } 23 \text {. }\end{array}$} \\
\hline
\end{tabular}


APPENDIX B

STORAGE REQUIREMENTS FOR

SOLAR APPLICATIONS 
SHACOB - PATH Hla

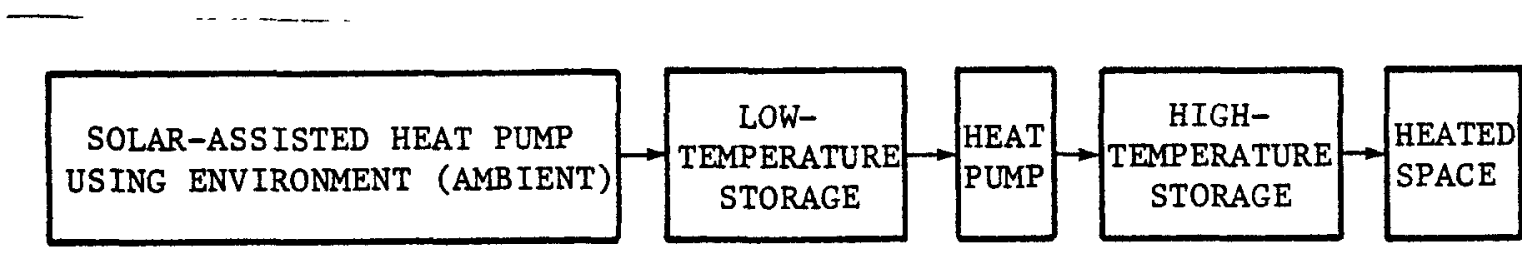

\section{LOW-TEMPERATURE STORAGE HIGH-TEMPERATURE STORAGE ${ }^{1}$} (not required)

\begin{tabular}{|c|c|c|}
\hline Temperature Range: & - & $85^{\circ}$ to $120^{\circ} \mathrm{F}$ \\
\hline $\begin{array}{l}\text { Storage Capacity: } \\
\text { Long Term - } \\
\text { Short Term - }\end{array}$ & - & $\begin{array}{l}1 \text { day's supply of heating } \\
\text { design load. } 2\end{array}$ \\
\hline $\begin{array}{l}\text { Storage Time: } \\
\text { Long Term - } \\
\text { Short Term - }\end{array}$ & - & - day \\
\hline $\begin{array}{l}\text { Charge Time Per Cycle: } \\
\text { Long Term - } \\
\text { Short Term - }\end{array}$ & - & $\overline{6}$ to 12 hours \\
\hline $\begin{array}{l}\text { Discharge Time Per } \\
\text { Cycle: } \\
\text { Long Term - } \\
\text { Short Term - }\end{array}$ & - & $\overline{1} \mathrm{c} / \mathrm{day}$ \\
\hline $\begin{array}{l}\text { Acceptable Life Cycle } \\
\text { Cost (LCC) }\end{array}$ & - & $\begin{array}{l}\text { System LCC should not } \\
\text { exceed LCC for heat pump } \\
\text { without hIgh temperature } \\
\text { storage. }\end{array}$ \\
\hline
\end{tabular}

1. High temperature storage allows peak load shaving by use of a heat pump during off-peak hours.

2. The heating design load is selected at ASHRAE 97-1/2 percent winter design conditions. However, only 60 to 80 percent of the seasonal heating load is expected to be furnished by solar energy. 
SHACOB - PATH HIa

(Continued)

Suggested path Hla:

\begin{tabular}{|c|c|c|c|}
\hline $\begin{array}{l}\text { SOLAR-ASSISTED HEAT PUMP } \\
\text { USING ENVIRONMENT (AMBIENT) }\end{array}$ & $\begin{array}{l}\text { HEAT } \\
\text { PUMP }\end{array}$ & $\begin{array}{c}\text { HIGH } \\
\text { TEMPERATURE }\end{array}$ & HEATED \\
\hline & & & \\
\hline
\end{tabular}


SHACOB - PATH HIb

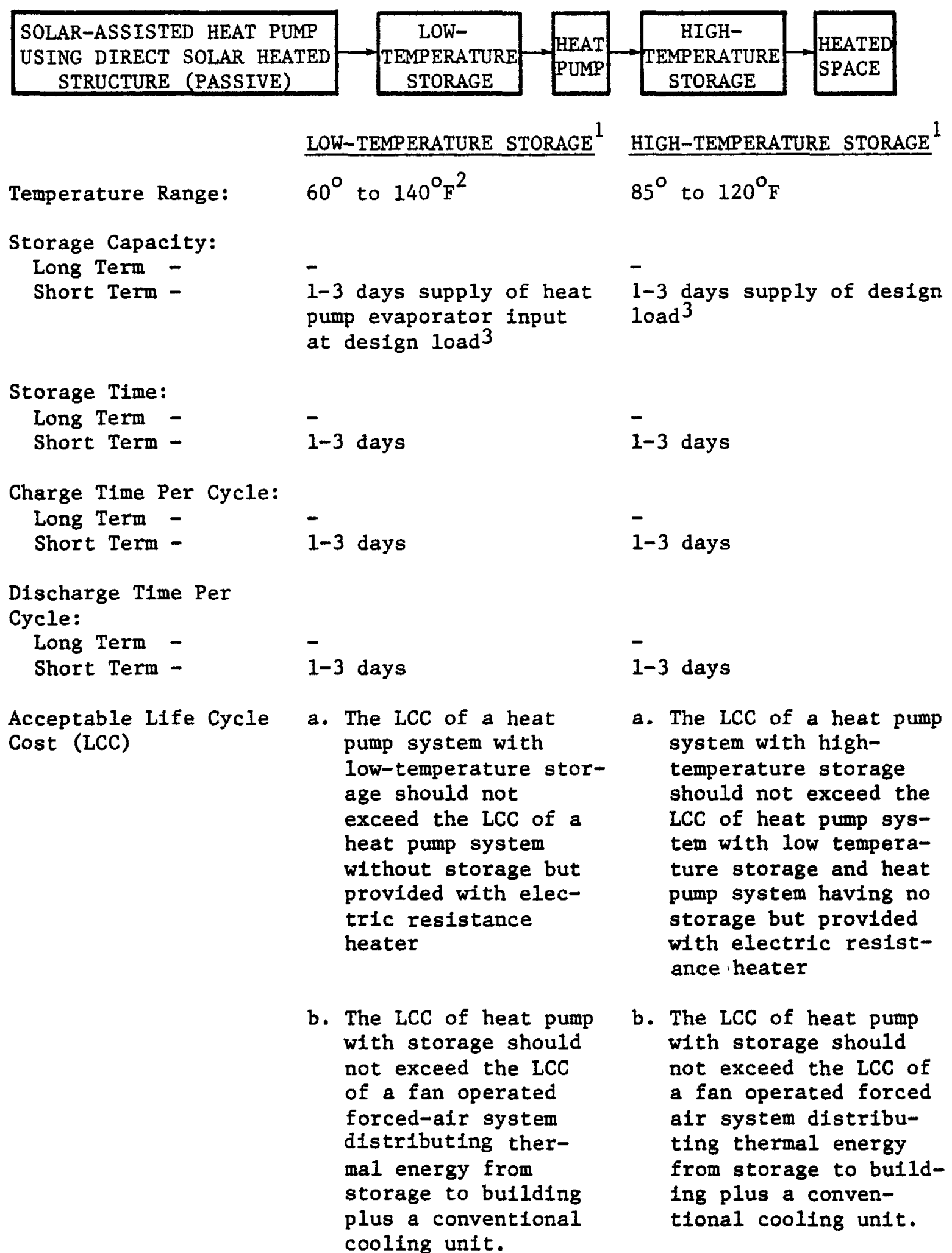


SHACOB - PATH H1b

(Continued)

Suggested path Hlb:

SOLAR-ASSISTED HEAT PUMP

USING DIRECT SOLAR HEATED

STRUCTURE (PASSIVE)
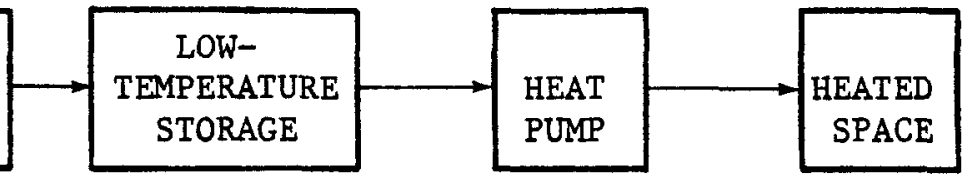

1. The low temperature storage provides for an above-ambient temperature energy input to the heat pump evaporator. Additional storage for load leveling on the condenser side would generally be difficult to justify on a life cycle cost basis. The use of storage units when the heat pump is operating in the cooling mode must also be considered in the design of a system for a specific application.

2. The most convenient heat transfer fluid for a direct solar heated structure is air. For an air-to-air heat pump, the temperature of the air which transfers energy from structure storage to the evaporator could be controlled at a favorable range of $50^{\circ}$ to $70^{\circ} \mathrm{F}$ even at a much higher storage temperature of $60^{\circ}$ to $140^{\circ} \mathrm{F}$.

3. The heating design load is selected ASHRAE 97-1/2 percent winter design conditions. However, only 60 to 80 percent of the seasonal heating load is expected to be furnished by solar energy. 
SHACOB - PATH HIC

\begin{tabular}{|c|c|c|c|c|}
\hline $\begin{array}{c}\text { SOLAR-ASSISTED HEAT PUMP } \\
\text { WITH }\end{array}$ & \begin{tabular}{|l} 
LOW- \\
TEMPERATURE
\end{tabular} & HE & $\begin{array}{c}\text { HIGH- } \\
\text { TEMPERATURE }\end{array}$ & ED \\
\hline LIOUID HEATING COLLECTORS & STORAGE & |PUM & STORAGE & $\triangle C E$ \\
\hline
\end{tabular}

\begin{tabular}{|c|c|c|}
\hline & LOW-TEMPERATURE STORAGE ${ }^{1}$ & HIGH-TEMPERATURE STORAGE \\
\hline Temperature Range: & $40^{\circ}$ to $90^{\circ} \mathrm{F}^{2}$ & $85^{\circ}$ to $120^{\circ} \mathrm{F}$ \\
\hline \multicolumn{3}{|l|}{ Storage Capacity: } \\
\hline Long Term - & $\begin{array}{l}90 \text { to } 100 \text { percent sea- } \\
\text { sonal heating energy } \\
\text { input required for } \\
\text { heat pump evaporator }\end{array}$ & - \\
\hline Short Term - & $\begin{array}{l}\text { 1-3 days supply of heat } \\
\text { pump evaporator in- } \\
\text { put at design load }\end{array}$ & $\begin{array}{l}\text { 1-3 days supp } 1 \text { y of } \\
\text { design load } 3\end{array}$ \\
\hline $\begin{array}{l}\text { Storage Time: } \\
\text { Long Term - } \\
\text { Short Term - }\end{array}$ & $\begin{array}{l}3-6 \text { months } \\
1-3 \text { days }\end{array}$ & $\overline{1-3}$ days \\
\hline $\begin{array}{l}\text { Charge Time Per Cycle: } \\
\text { Long Term - } \\
\text { Short Term - }\end{array}$ & $\begin{array}{l}3-6 \text { months } \\
1-3 \text { days }\end{array}$ & $\overline{1-3}$ days \\
\hline $\begin{array}{l}\text { Discharge Time Per } \\
\text { Cycle: } \\
\text { Long Term - } \\
\text { Short Term - }\end{array}$ & $\begin{array}{l}3-6 \text { months } \\
1-3 \text { days }\end{array}$ & $\overline{1}-3$ days \\
\hline $\begin{array}{l}\text { Acceptable Life Cycle } \\
\text { Cost (LCC) }\end{array}$ & $\begin{array}{l}\text { The LCC of a heat pump } \\
\text { system with low-tem- } \\
\text { perature storage should } \\
\text { not exceed the LCC of } \\
\text { heat pump system without } \\
\text { storage but provided } \\
\text { with electric resis- } \\
\text { tance heater }\end{array}$ & $\begin{array}{l}\text { The LCC of a heat pump } \\
\text { system with high-tem- } \\
\text { perature storage should } \\
\text { not exceed the LCC of a } \\
\text { heat pump system without } \\
\text { h1gh-temperature storage } \\
\text { or without any storage }\end{array}$ \\
\hline
\end{tabular}


SHACOB - PATH H1C

(Continued)

Suggested path Hlc:

\begin{tabular}{|c|c|c|c|}
\hline $\begin{array}{c}\text { SOLAR-ASSISTED HEAT PUMP } \\
\text { WITH }\end{array}$ & $\begin{array}{l}\text { LOW- } \\
\text { TEMPERATURE }\end{array}$ & HEAT & HEATED \\
\hline LIQUID HEATING COLLECTORS & STORAGE & PUMP & SPACE \\
\hline
\end{tabular}

1. The low-temperature storage will in general provide the storage capacity needed to operate a heat pump. Additional high-temperature storage on the condensing side of the heat pump is not justified.

2. If the temperature exceeds $90^{\circ} \mathrm{F}$ in low-temperature storage, the heat pump may be bypassed.

3. The heating design load is selected at ASHRAE 97-1/2 percent winter design conditions. For a series heat pump system, the capacity of the solar supplied low-temperature storage should be selected to provide 80 to 100 percent of the seasonal energy required by the heat pump evaporator. For a parallel system, this percentage could be lower since the heat pump is selected for stand-alone operation. 


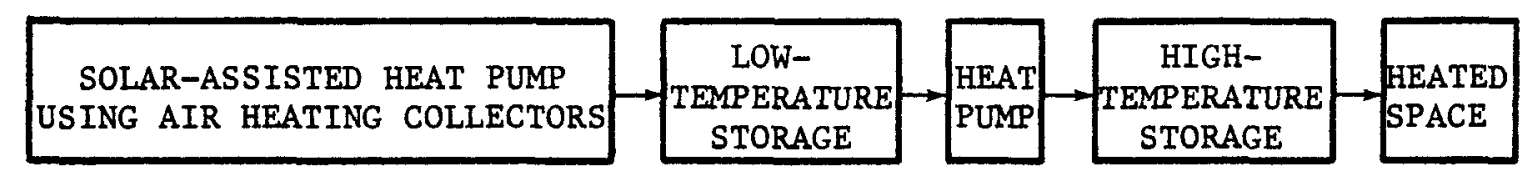

\section{LOW-TEMPERATURE STORAGE $^{1}$ HIGH-TEMPERATURE STORAGE ${ }^{1}$}

\begin{tabular}{|c|c|}
\hline Temperature Range: & $40^{\circ}$ to $90^{\circ} \mathrm{F}^{2}$ \\
\hline $\begin{array}{l}\text { Storage Capacity: } \\
\text { Long Term - } \\
\text { Short Term - }\end{array}$ & $\begin{array}{l}\text { 1-3 days supply heat } \\
\text { pump evaporator input } \\
\text { design load }{ }^{2}\end{array}$ \\
\hline $\begin{array}{l}\text { Storage Time: } \\
\text { Long Term - } \\
\text { Short Term - }\end{array}$ & $\overline{1-3}$ days \\
\hline $\begin{array}{l}\text { Charge Time Per Cycle: } \\
\text { Long Term - } \\
\text { Short Term - }\end{array}$ & $\overline{1}-3$ days \\
\hline $\begin{array}{l}\text { Discharge Time Per } \\
\text { Cycle: } \\
\text { Long Term - } \\
\text { Short Term - }\end{array}$ & $\overline{1-3}$ days \\
\hline $\begin{array}{l}\text { Acceptable Life Cycle } \\
\text { Cost (LCC): }\end{array}$ & $\begin{array}{l}\text { The LCC of a heat pump } \\
\text { system with low-tem- } \\
\text { perature storage should } \\
\text { not exceed the LCC of a } \\
\text { heat pump without stor- } \\
\text { age but provided with } \\
\text { electric resistance } \\
\text { heater }\end{array}$ \\
\hline
\end{tabular}

Acceptable Cost Level: This system is competing with a heat pump system without storage $85^{\circ}$ to $120^{\circ} \mathrm{F}$

$-$

1-3 days supply at the design load 2

-

1-3 days

$\overline{1-3}$ days

1-3 days

The ICC of a heat pump system with high-temperature storage should not exceed the LCC of a heat pump system with low temperature storage and heat pump system having no storage but provided with electric resistance heater

This system is competing with a heat pump system without high-temperature storage or without any storage 
Suggested path HId:

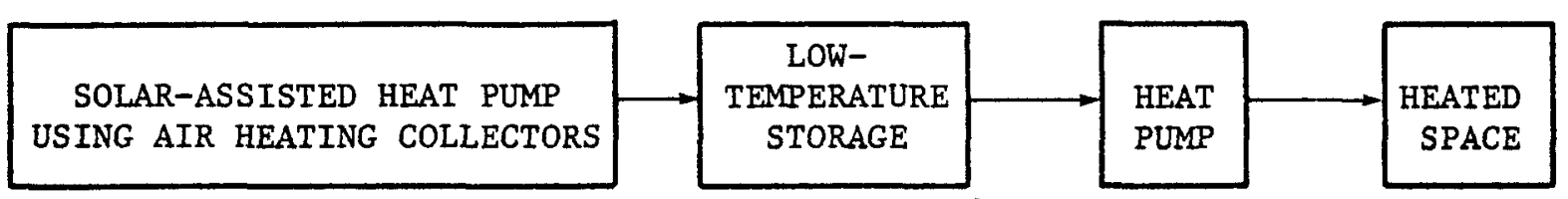

1. The low temperature storage provides for an above-ambient temperature energy to the heat pump evaporator. Additional storage for load leveling on the condenser side would generally be difficult to justify on a life cycle cost basis. The use of storage units when the heat pump is operating in the cooling mode must also be considered in the design of a system for a specific application.

2. For air collector applications with heat pump, the air-to-air heat pump provides is a good match. This type of heat pump can operate with a wide range of evaporator temperatures, from $-20^{\circ}$ to $110^{\circ} \mathrm{F}$. The commonly applied favorable heat source temperature is approximately $40^{\circ}$ to $60^{\circ} \mathrm{F}$. The heating design load is selected to be at ASHRAE 97-1/2 percent winter design conditions. However, only 60 to 80 percent of the seasonal heating load is expected to be furnished by solar energy storage. 


\section{SHACOB - PATH Hle}

\begin{tabular}{|c|c|c|c|c|}
\hline SOLAR-ASSISTED HEAT PUMP & LOW- & $|\mathrm{HEAT}|$ & HIGH- & IHEATED \\
\hline $\begin{array}{l}\text { USING ADVANCED NON- } \\
\text { CONCENTRATING COLLECTORS }\end{array}$ & $\begin{array}{l}\text { TEMPERATURE } \\
\text { STORAGE }\end{array}$ & PUMP & $\begin{array}{l}\text { TEMPERATURE } \\
\text { STORAGE }\end{array}$ & SPACE \\
\hline
\end{tabular}

LOW-TEMPERATURE STORAGE $^{1}$ HIGH-TEMPERATURE STORAGE ${ }^{1}$

\begin{abstract}
Temperature Range:
Storage Capacity:

Long Term -
\end{abstract}

Short Term -

Storage Time:

Long Term -

Short Term -

Charge Time Per Cycle:

Long Term -

Short Term -

Discharge Time Per

Cycle:

Long Term -

Short Term -

Acceptable Life Cycle Cost (LCC): $40^{\circ}$ to $90^{\circ} \mathrm{F}^{2}$

$85^{\circ}$ to $120^{\circ} \mathrm{F}$

90 to 100 percent seasonal heating energy input required for heat pump evaporator

1-3 days supply of a heat pump evaporator input at design load 3

3-6 months

1-3 days

3-6 months

1-3 days

3-6 months

1-3 days

The LCC of a heat pump system with low-temperature storage should not exceed the LCC of heat pump system without storage but provided with electric resistant heater
1-3 days supply of design load 3

$-$

1-3 days

1-3 days

$-$

1-3 days

The LCC of a heat pump system with high-temperature storage should not exceed the ICC of a heat pump system without hightemperature storage or without any storage 


\section{SHACOB - PATH Hle}

\section{(Continued)}

Suggested path Hle:

The path Hle may be deleted since the selection of an advanced non-concentrating collector and heat pump would normally not be an economical combination. On the other hand, a group of storage units which are also acting as the collector has not been covered by DOE's program paths. Specific examples are fiberglass storage tubes of Kalwall Corporation and a salt gradient solar pond. A new path is suggested as follows:

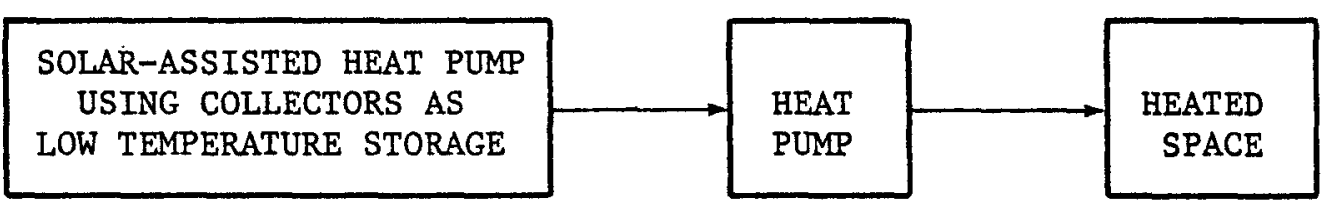

1. The low temperature storage provides for an above-ambient temperature energy to the heat pump evaporator. Additional storage for load leveling on the condenser side would generally be difficult to justify on a life cycle cost basis. The use of storage units when the heat pump is operating in the cooling mode must also be considered in the design of a system for a specific application.

2. If the temperature exceeds $90^{\circ} \mathrm{F}$ in low-temperature storage, the heat pump may be bypassed.

3. The heating design load is selected at ASHRAE 97-1/2 percent winter design conditions. For a series heat pump system, the capacity of the solar supplied low-temperature storage should be carefully selected to provide 80 to 100 percent of the seasonal energy required by heat pump evaporator. For a parallel system, this percentage could be lower since the heat pump is selected for stand-alone operation. 


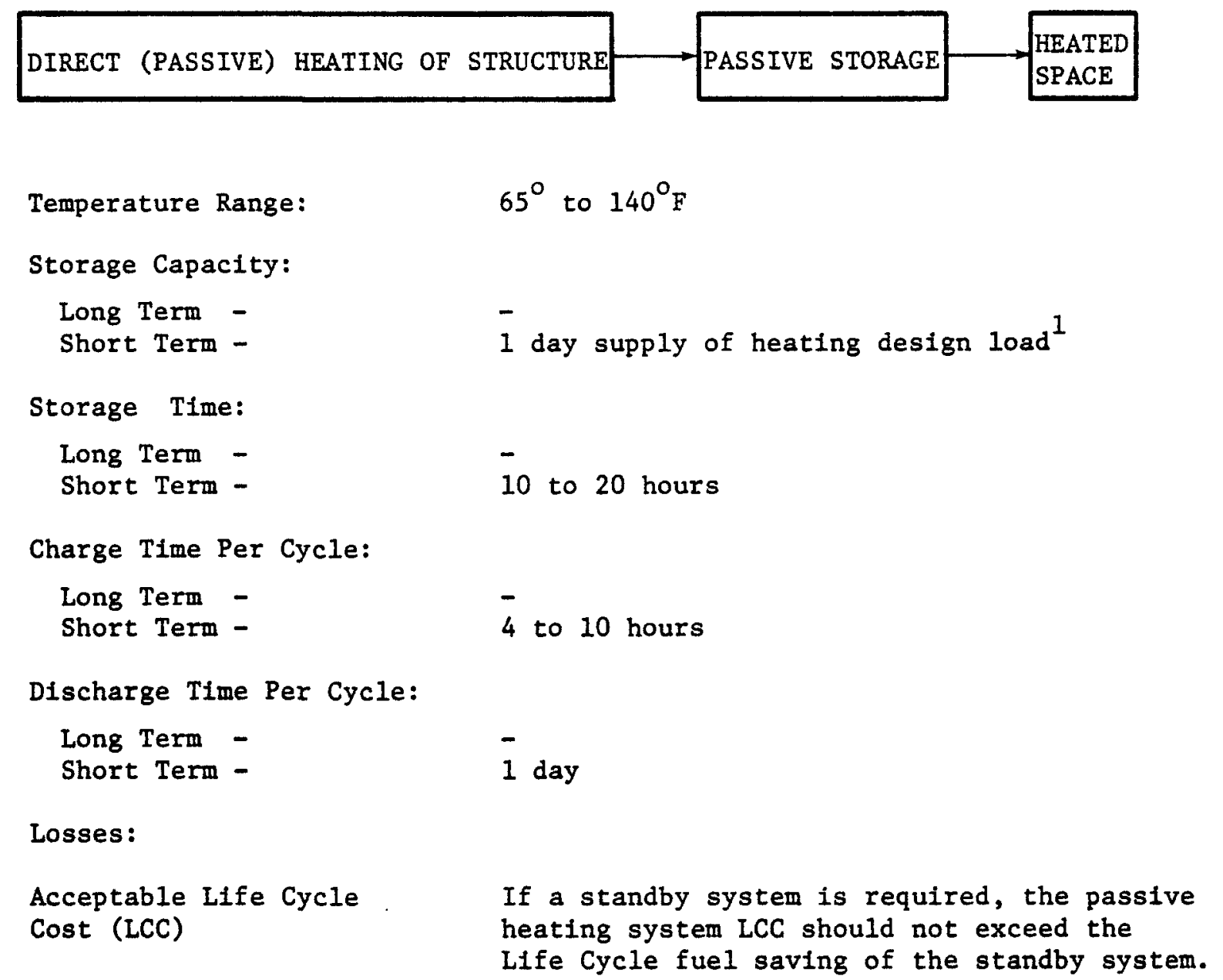

1. The heating design load is selected at ASHRAE 97-1/2 percent winter design conditions. However, a seasonal heating load supply of 50 to 70 percent for a passive heating system may be satisfactory. 


\section{SHACOB - PATH H3a}

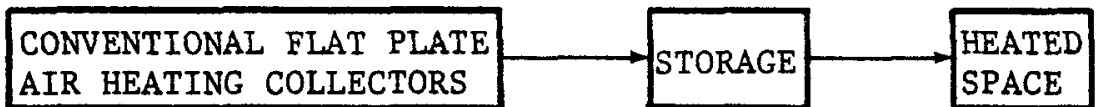

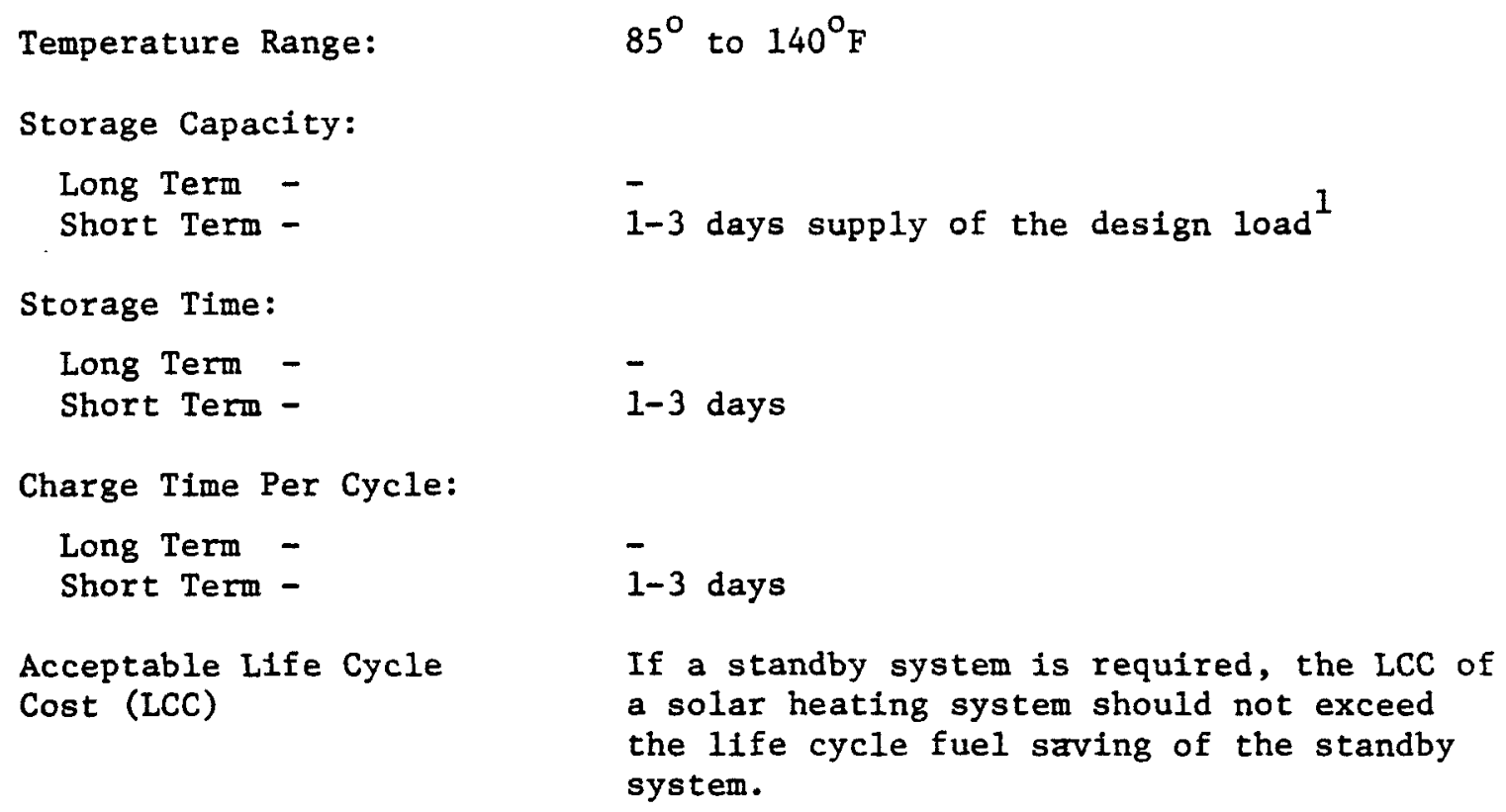

1. The heating design load is selected at ASHRAE 97-1/2 percent winter design conditions, however, an average of 60 to 80 percent of seasonal heating load is expected to be provided. 


ADVANCED NON-CONCENTRATING
AIR HEATING COLLECTORS $\longrightarrow$ STORAGE

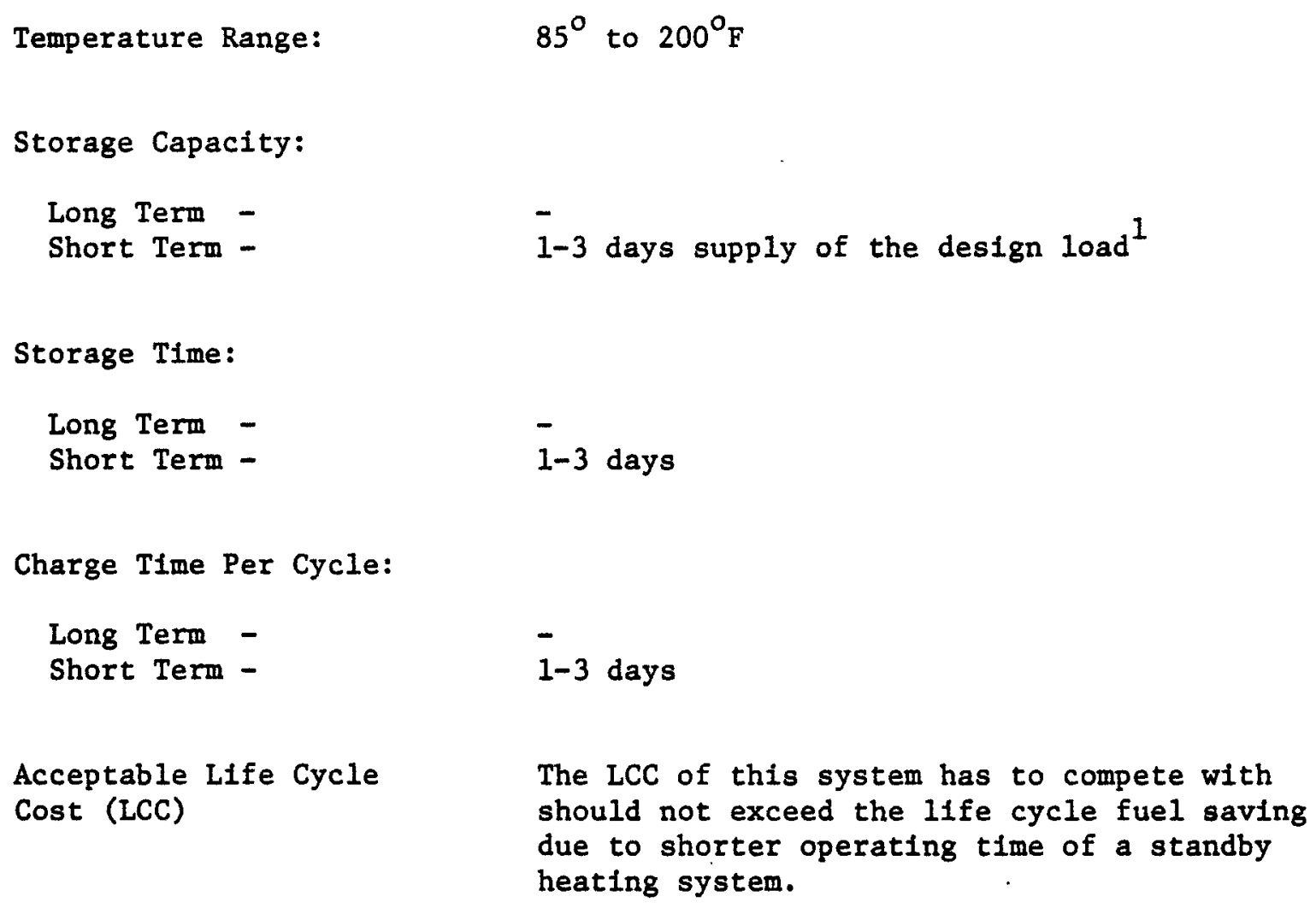

Storage Time:

Long Term -

Short Term -$$
\text { 1-3 days }
$$

Charge Time Per Cycle:

Long Term -

Short Term -

Acceptable Life Cycle Cost (LCC)

\section{1-3 days}

The LCC of this system has to compete with should not exceed the life cycle fuel saving due to shorter operating time of a standby heating system.

1. The heating design load is selected at ASHRAE 97-1/2 percent winter design conditions, however, an average of 60 to 80 percent of seasonal heating load is expected to be provided. 

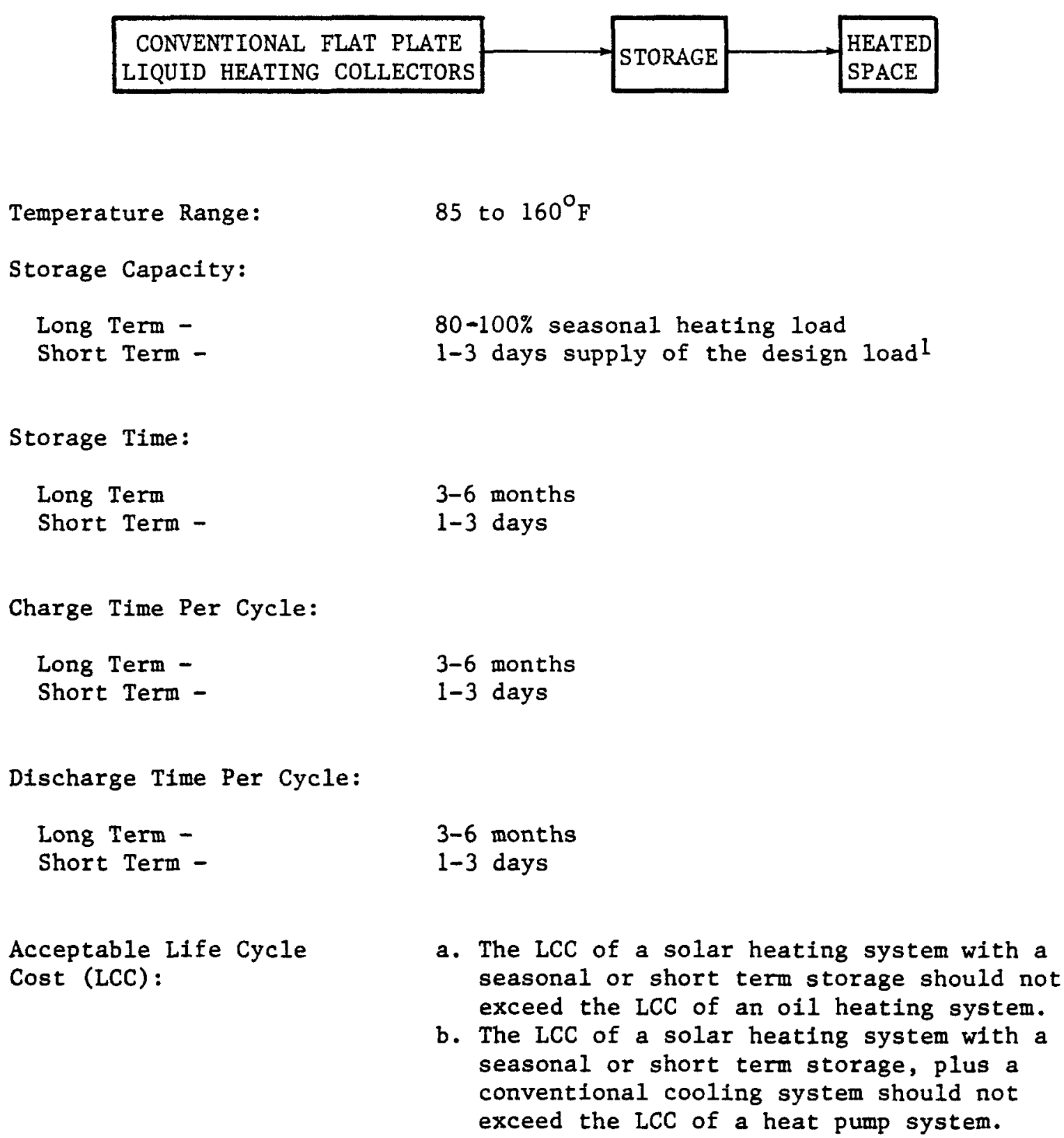

Storage Time:

Long Term

Short Term -

3-6 months

1-3 days
Long Term -
3-6 months
Short Term -
1-3 days

Charge Time Per Cycle:

Discharge Time Per Cycle:
Long Term -
3-6 months
Short Term -
1-3 days

Acceptable Life Cycle Cost (LCC) :

a. The LCC of a solar heating system with a seasonal or short term storage should not exceed the LCC of an oil heating system.

b. The LCC of a solar heating system with a seasonal or short term storage, plus a conventional cooling system should not exceed the LCC of a heat pump system.

1. The heating design load is selected at ASHRAE 97-1/2 percent winter design conditions. However, only 60-80 percent of the seasonal heating load is expected to be furnished by solar energy. 


\section{SHACOB - PATH H4b}

ADVANCED NON-CONCENTRATING
LIQUID HEATING COLLECTORS $\longrightarrow$ STORAGE

Temperature Range:

Storage Capacity:

Long Term -

Short Term -

Storage Time:

Long Term -

Short Term -

Charge Time Per Cycle:

Long Term -

Short Term -

Discharge Time Per Cycle:

Long Term -

Short Term -

Acceptable Life Cycle

Cost (LCC):
85 to $200^{\circ} \mathrm{F}$

80-100\% seasonal heating load

1-3 days supply of the design load

3-6 months

1-3 days

3-6 months

1-3 days

3-6 months

1-3 days

a. The LCC of a solar heating system with a seasonal or short term storage should not exceed the LCC of an oil heating system.

b. The LCC of a solar heating system with a seasonal or short term storage, plus a conventional cooling system should not exceed the ICC of a heat pump system.

1. The heating design load is selected at ASHRAE 97-1/2 percent winter design conditions. However, only 60-80 percent of the seasonal heating load is expected to be furnished by solar energy. 
SHACOB - PATHS C1 AND C2

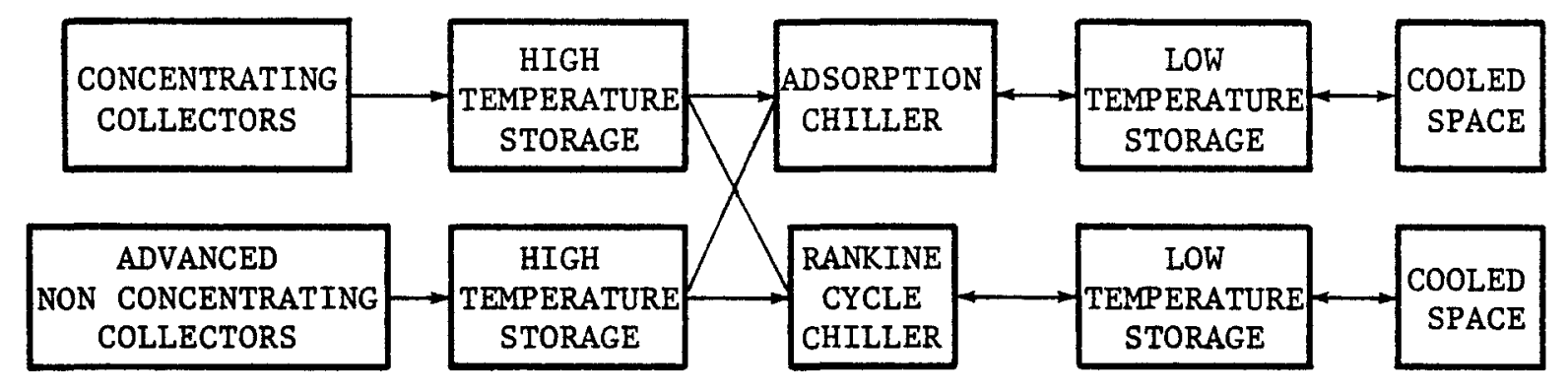

C1. CONCENTRATING COLLECTORS

C2. ADVANCED NON-CONCENTRATING COLLECTORS

\begin{tabular}{|c|c|c|}
\hline & HIGH-TEMPERATURE STORAGE ${ }^{1}$ & LOW-TEMPERATURE STORAGE ${ }^{1}$ \\
\hline Temperature Range: & $\begin{array}{l}\text { Rankine (C1): } 300^{\circ} \text { to } \\
700^{\circ} \mathrm{F} \\
\text { Rankine (C2): } 180^{\circ} \text { to } \\
350^{\circ} \mathrm{F} \\
\text { Absorption (C2): } 180^{\circ} \\
\text { to } 350^{\circ} \mathrm{F}\end{array}$ & $\begin{array}{ll}\text { Sensible: } & 35^{\circ} \text { to } 50^{\circ} \mathrm{F} \\
\text { PCM: } & 45^{\circ} \text { to } 50^{\circ} \mathrm{F}\end{array}$ \\
\hline $\begin{array}{l}\text { Storage Capacity: } \\
\text { Long Term - } \\
\text { Short Term - }\end{array}$ & $\begin{array}{l}\text { Avg. daily load } 1 \text { /avg. } \\
\text { COP }\end{array}$ & - \\
\hline $\begin{array}{l}\text { Storage Time: } \\
\text { Long Term - } \\
\text { Short Term - }\end{array}$ & $\overline{1}$ to 3 days & $\overline{1}$ to 3 days \\
\hline $\begin{array}{l}\text { Charge Time Per Cycle: } \\
\text { Long Term - } \\
\text { Short Term - }\end{array}$ & $\overline{1}$ day & $\overline{1}$ day \\
\hline $\begin{array}{l}\text { Discharge Time Per } \\
\text { Cycle: } \\
\text { Long Term - } \\
\text { Short Term - }\end{array}$ & $\overline{1}$ day & $\overline{1}$ day \\
\hline
\end{tabular}




\section{$\frac{\text { SHACOB }- \text { PATHS C1 AND C2 }}{\text { (Continued) }}$}

HIGH-TEMPERATURE STORAGE $^{1}$ LOW-TEMPERATURE STORAGE ${ }^{1}$

Acceptable Life Cycle Cost (LCC);
The LCC of a solar cooling system with hightemperature storage should not exceed the LCC of a steam absorption cooling system.
The LCC of a solar cooling system with lowtemperature storage should not exceed the LCC of the same system without low-temperature storage.

1. Average daily load should be estimated over the cooling season.

2. Depending on system design and contribution made by storage to system technical performance and economics, storage cost for solar cooling systems is generally about 5 to 10 percent of installed system cost. 


\section{SHACOB - PATH C4}

\begin{tabular}{|c|l|l|}
\hline $\begin{array}{c}\text { EVAPORATIVE NIGHT } \\
\text { TIME COOLING }\end{array}$ & $\begin{array}{l}\text { POOLED } \\
\text { PASSIVE } \\
\text { STORAGE }\end{array}$ \\
\hline
\end{tabular}

\begin{tabular}{|c|c|}
\hline Temperature Range: & 35 to $70^{\circ} \mathrm{F}$ \\
\hline Storage Capacity: & \\
\hline $\begin{array}{l}\text { Long Term - } \\
\text { Short Term - }\end{array}$ & $\overline{1}$ day supply of cooling design load ${ }^{1}$ \\
\hline Storage Time: & \\
\hline $\begin{array}{l}\text { Long Term - } \\
\text { Short Term - }\end{array}$ & $\overline{8} 20$ hours \\
\hline
\end{tabular}

Charge Time Per Cycle:

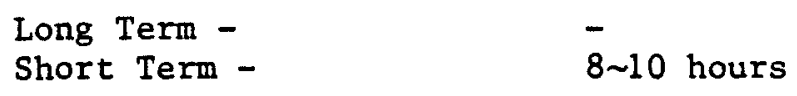

Discharge Time Per Cycle:

Long Term -

Short Term - $\quad \$ 0 \sim 12$ hours

Acceptable Life Cycle Cost (LCC):

The LCC of evaporative or nighttime cooling system should not exceed the LCC of a conventional cooling system, or a heat pump system.

1. Cooling design load is selected at ASHRAE 5 percent summer design conditions.

2. The weater conditions for effective evaporative and/or nighttime cooling are high outdoor temperature differentials between daytime and nighttime and low humidity. If the daytime humidity is low, an evaporative cooling system may work effectively. If the nighttime temperature is low, nighttime radiation plus night time evaporation may be satisfactory. 
SHACOB - PATH C5

\begin{tabular}{|c|c|c|c|c|}
\hline COOLING BY & HIGH & HEAT & LOW & COOLE \\
\hline HEAT PUMP & $\begin{array}{c}\text { TEMPERATURE } \\
\text { STORAGE }\end{array}$ & PUMP & $\begin{array}{l}\text { TEMPERATURE } \\
\text { STORAGE }\end{array}$ & SPACE \\
\hline
\end{tabular}

Similar to solar assisted heat pump paths Hla through Hle, except that

- The process is reversed where the evaporator becomes the condenser and the condenser becomes the evaporator

- The high temperature storage becomes the low temperature storage, and the low temperature storage becomes the high temperature storage

- The heat pump may reject thermal energy directly to environment, or to storage and then dissipate the energy via collectors, fan-coil units or cooling towers. 


\section{AIPH - PATH HD}

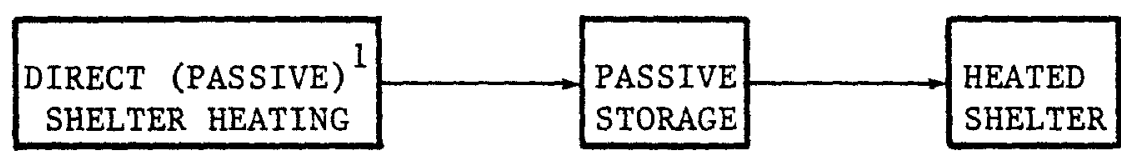

Temperature Range:

45 to $140^{\circ} \mathrm{F}$

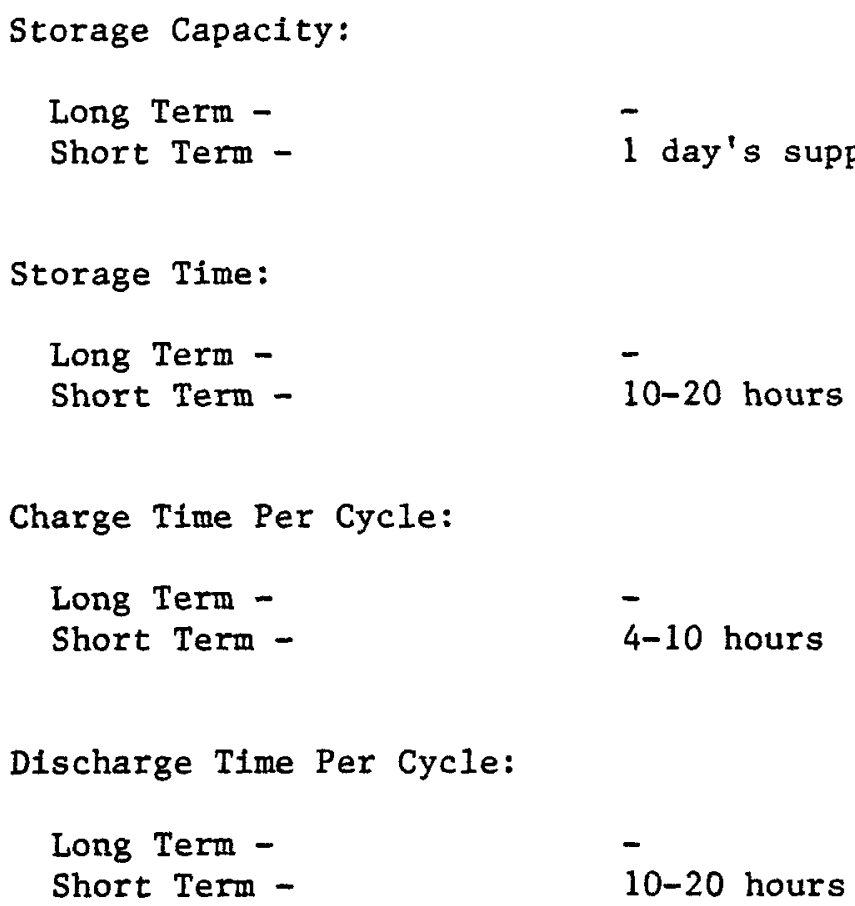

Acceptable Life Cycle Cost (LCC):

If a standby system is required, the LCC of a passive heating system with storage should not exceed the Life Cycle fuel saving of the standby system.

1. To insulate a passively heated material is rather difficult. A permanent insulation installation requires high emissivity and low conductivity material. A portable insulation requires tight fit, light weight and should be easy to operate twice a day.

2. The heating design load is selected at ASHRAE 97-1/2 percent winter weather conditions. The indoor design conditions may vary from applications to applications. 


\section{AIPH - PATH HA}

AIR HEATING
COLLECTORS $\longrightarrow$ STORAGE $\longrightarrow$ HEATED

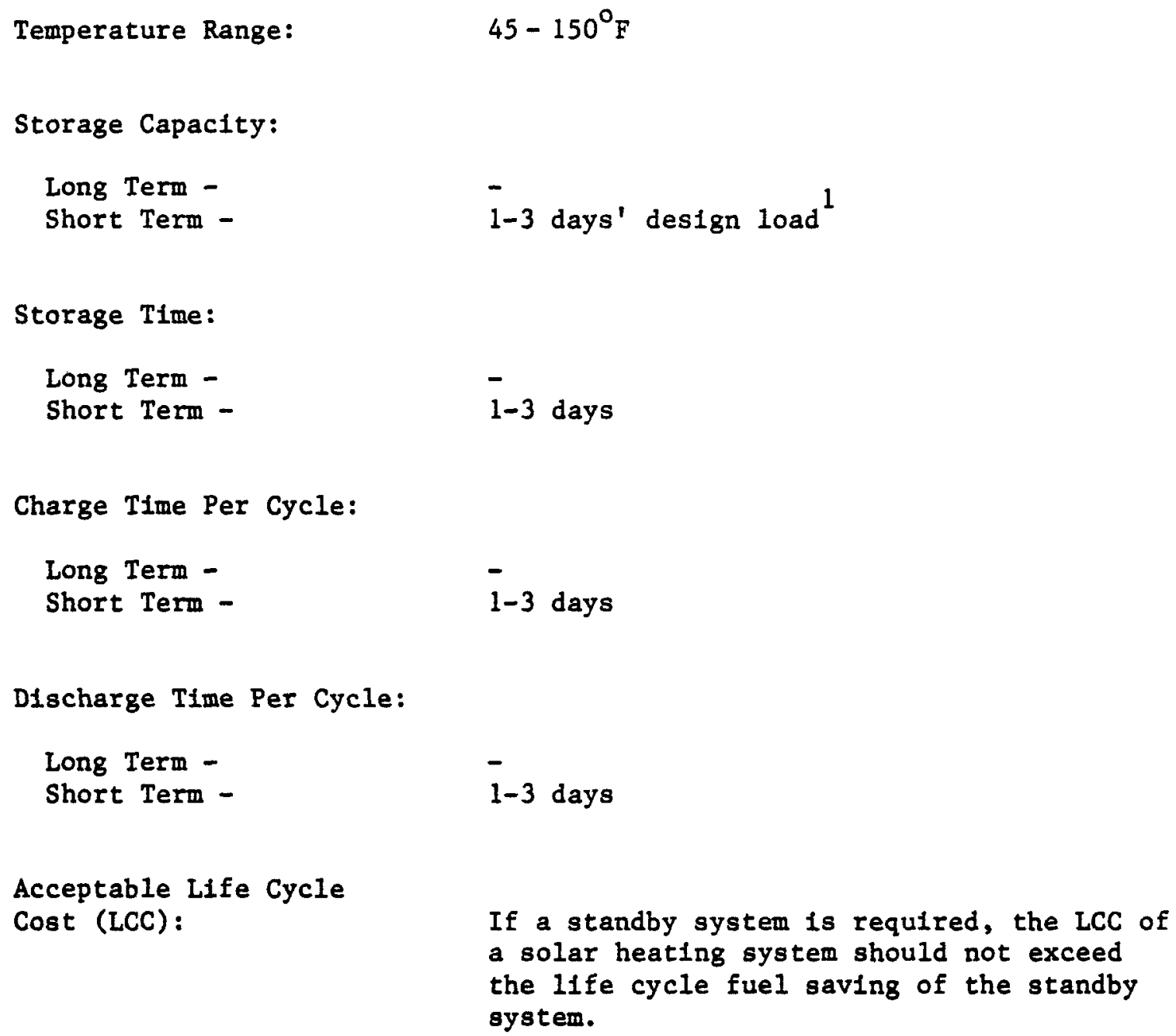

Discharge Time Per Cycle:

Long Term -

Short Term -

1-3 days

Acceptable Life Cycle

Cost (LCC) :

If a standby system is required, the LCC of a solar heating system should not exceed the life cycle fuel saving of the standby system.

1. The heating design load varies considerably with the intended application. The industrial and agriculture shelter heating applications could range from freeze protection to rather hot tropical weather conditions. The winter outdoor weather for design is selected at ASHRAE $97-1 / 2$ percent winter design conditions and the indoor design conditions are application dependent. 
AIPH - PATH HL

\begin{tabular}{|l}
\hline $\begin{array}{c}\text { LIQUID HEATING } \\
\text { COLLECTORS }\end{array}$ \\
STORAGE
\end{tabular}$\longrightarrow \begin{aligned} & \text { HEATED } \\
& \text { SHELTER }\end{aligned}$

\begin{tabular}{|c|c|}
\hline Temperature Range: & $60-180^{\circ} \mathrm{F}$ \\
\hline $\begin{array}{l}\text { Storage Capacity: } \\
\text { Long Term - } \\
\text { Short Term - }\end{array}$ & $\begin{array}{l}9010 \text { percent seasonal heating load } \\
1-3 \text { days design load } 1\end{array}$ \\
\hline $\begin{array}{l}\text { Storage Time: } \\
\text { Long Term - } \\
\text { Short Term - }\end{array}$ & $\begin{array}{l}3-6 \text { months } \\
1-3 \text { days }\end{array}$ \\
\hline $\begin{array}{l}\text { Charge Time Per Cycle: } \\
\text { Long Term - } \\
\text { Short Term - }\end{array}$ & $\begin{array}{l}3-6 \text { months } \\
1-3 \text { days }\end{array}$ \\
\hline $\begin{array}{l}\text { Discharge Time Per Cycle: } \\
\text { Long Term - } \\
\text { Short Term - }\end{array}$ & $\begin{array}{l}3-6 \text { months } \\
1-3 \text { days }\end{array}$ \\
\hline $\begin{array}{l}\text { Acceptable Life Cycle } \\
\text { Cost (LCC): }\end{array}$ & $\begin{array}{l}\text { a. The LCC of a solar heating system with a } \\
\text { seasonal or short-term storage should not } \\
\text { exceed the LCC of an oil heating system. } \\
\text { b. The LCC of a solar heating system with a } \\
\text { seasonal or short-term storage, plus a } \\
\text { conventional cooling system should not } \\
\text { exceed the LCC of a heat pump system. }\end{array}$ \\
\hline
\end{tabular}

1. The heating design load varies considerably with the intended application. The industrial and agriculture shelter heating applications could range from freeze protection to rather hot tropical weather conditions. The winter outdoor weather for design is selected at ASHRAE 97-1/2 percent winter design conditions and the indoor design conditions are application dependent. 
$\underline{A I P H}-\underline{P A T H}$ DA
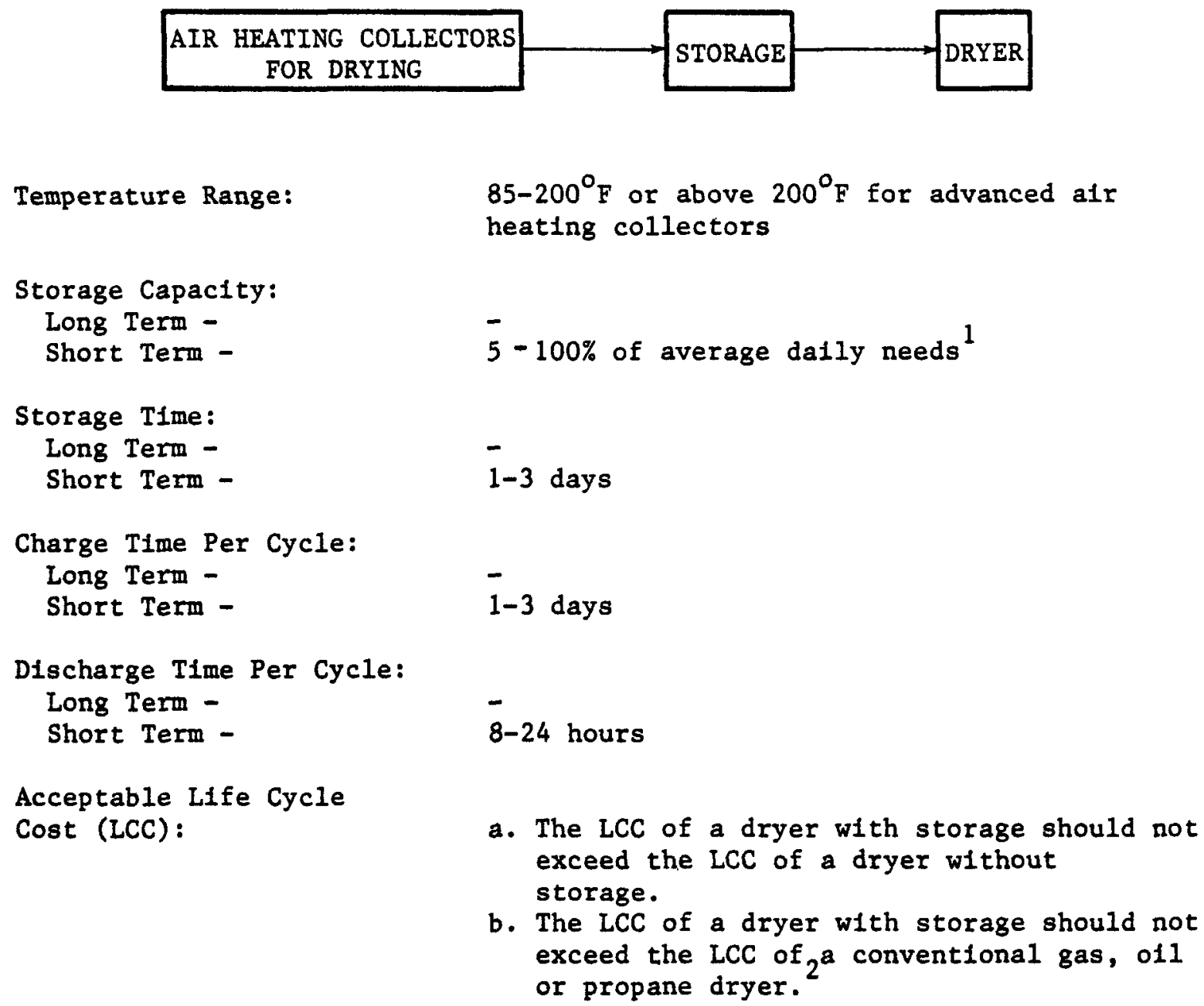

Acceptable Life Cycle Cost (LCC):

a. The LCC of a dryer with storage should not exceed the LCC of a dryer without storage.

b. The LCC of a dryer with storage should not

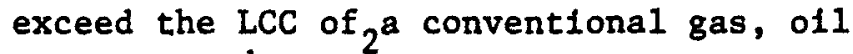
or propane dryer.

1. The range of industrial and agriculture drying applications can be very wide. To supply a small portion of energy for a large drying operation, the solar energy collected can be supplied directly from collectors to dryer without having a storage system. The air heating collectors and storage may be sized to supply 100 percent of average dally drying need. Depending on the design, a storage system capacity can vary from 5 percent to 100 percent of dally energy needs.

2. A solar thermal storage system for drying may not be cost effective for crop drying since the crop season is short. other non-drying applications assoctated with a drying system should be designed to offset the system cost. 
$\underline{A I P H}-\mathrm{PATH} D L$

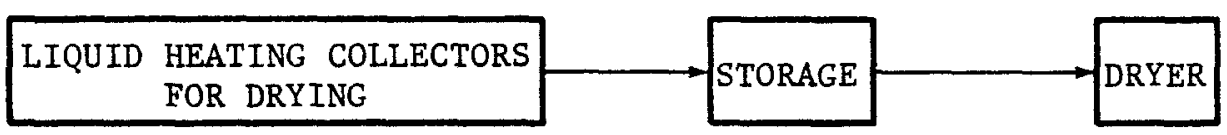

Temperature Range:

\section{Storage Capacity: \\ Long Term - \\ Short Term - \\ Storage Time: \\ Long Term -}

Short Term -

Charge Time Per Cycle:

Long Term

Short Term -

Discharge Time Per Cycle:

Long Term -

Short Term -

Acceptable Life Cycle

Cost (LCC):
85 to $200^{\circ} \mathrm{F}$ or 200 to $500^{\circ} \mathrm{F}$ for concentrating collectors

$80-100 \%$ of the total drying loag 1

5- $100 \%$ of the daily drying load

3-6 months

1-3 days

3-6 months

1-3 days

1-3 weeks

824 hours

a. The LCC of a dryer with storage should not exceed the LCC of a dryer without storage.

b. The LCC of a dryer with storage should not exceed the LCC of 3 conventional gas oil, or propane dryer.

1. The storage capacity for a long term storage system is selected to be 80100 percent of the total drying load. A long-term storage system for drying could mean that the thermal energy required for drying is collected and stored for a long period of time, however, the drying process may be completed in a very short period of 1-3 weeks since the crop season is short.

2. The short term storage capacity can have a very wide range depending on applications. One can have a storage system only supply a small portion of the total load with a complete standby system independent of solar energy. Or one may have a drying system heavily depending on solar energy.

3. A solar thermal storage system for crop drying alone may not be so cost effective. Since the crop season is short. Other non-drying applications associated with a drying system should be designed to offset the system cost. 


\section{AIPH - PATH SL}

$\begin{gathered}\text { ADVANCED LIQUID-HEATING } \\ \text { COLLECTORS FOR PROCESS } \\ \text { STEAM }\end{gathered}$
STORAGE

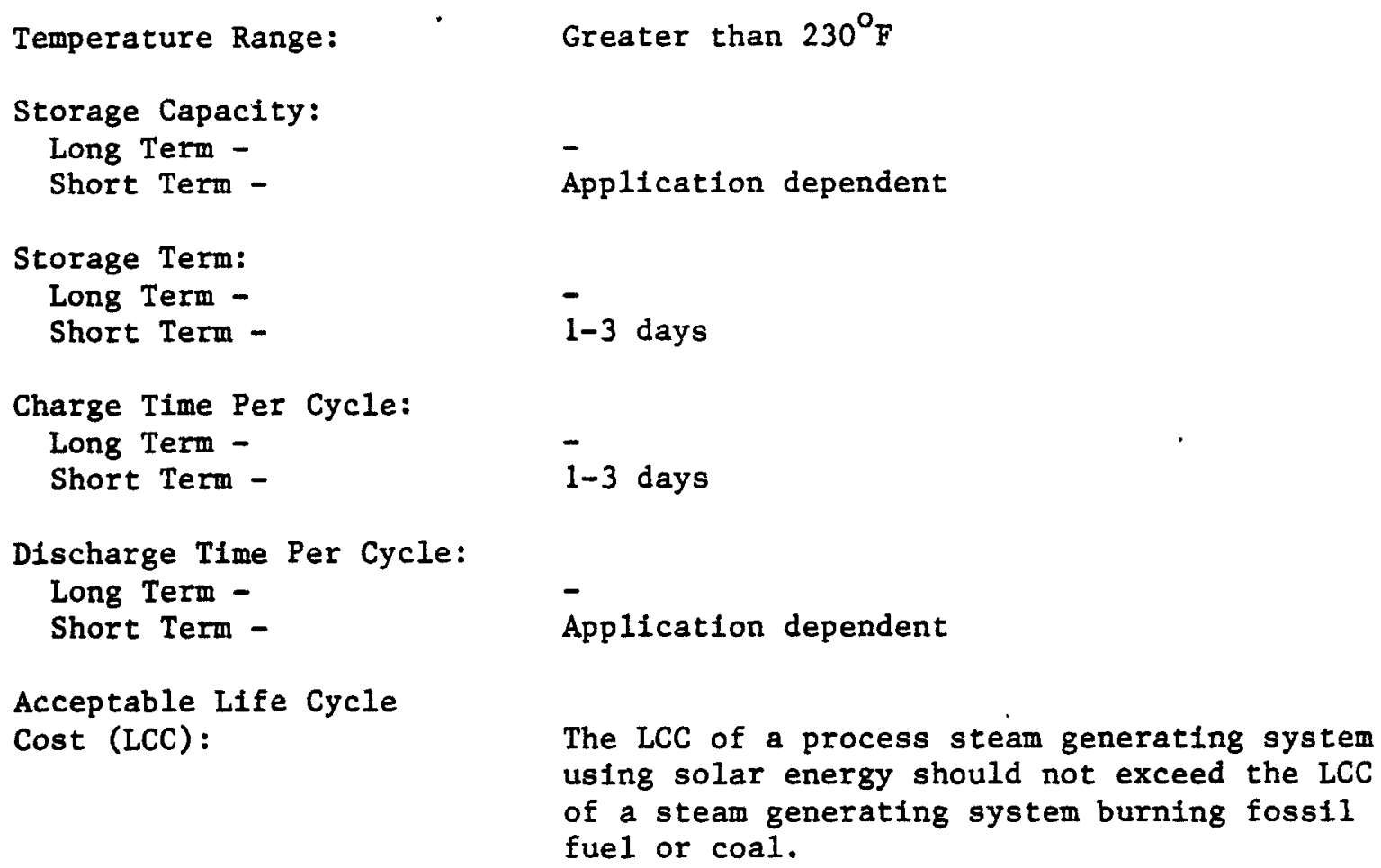

The LCC of a process steam generating system using solar energy should not exceed the LCC of a steam generating system burning fossil fuel or coal. 


\section{AIPH - PATH SA}

\begin{tabular}{|l|l|}
\hline $\begin{array}{c}\text { ADVANCED AIR HEATING } \\
\text { COLLECTORS FOR } \\
\text { PROCESS STEAM }\end{array}$ & PROCESS \\
STEAM & \\
\hline
\end{tabular}

Temperature Range:

Storage Capacity:

Long Term -

Short Term -

Storage Time:

Long Term -

Short Term -

Charge Time Per Cycle:

Long Term -

Short Term -

Discharge Time Per Cycle:

Long Term -

Short Term -

Acceptable Life Cycle

Cost (LCC):

\author{
Greater than $230^{\circ} \mathrm{F}$
}

Application dependent

$\overline{1-3}$ days

$\overline{1-3}$ days

-

Application dependent

The LCC of a process steam generating system using solar energy should not exceed the LCC of a steam generating system burning fossil fuel or coal. 


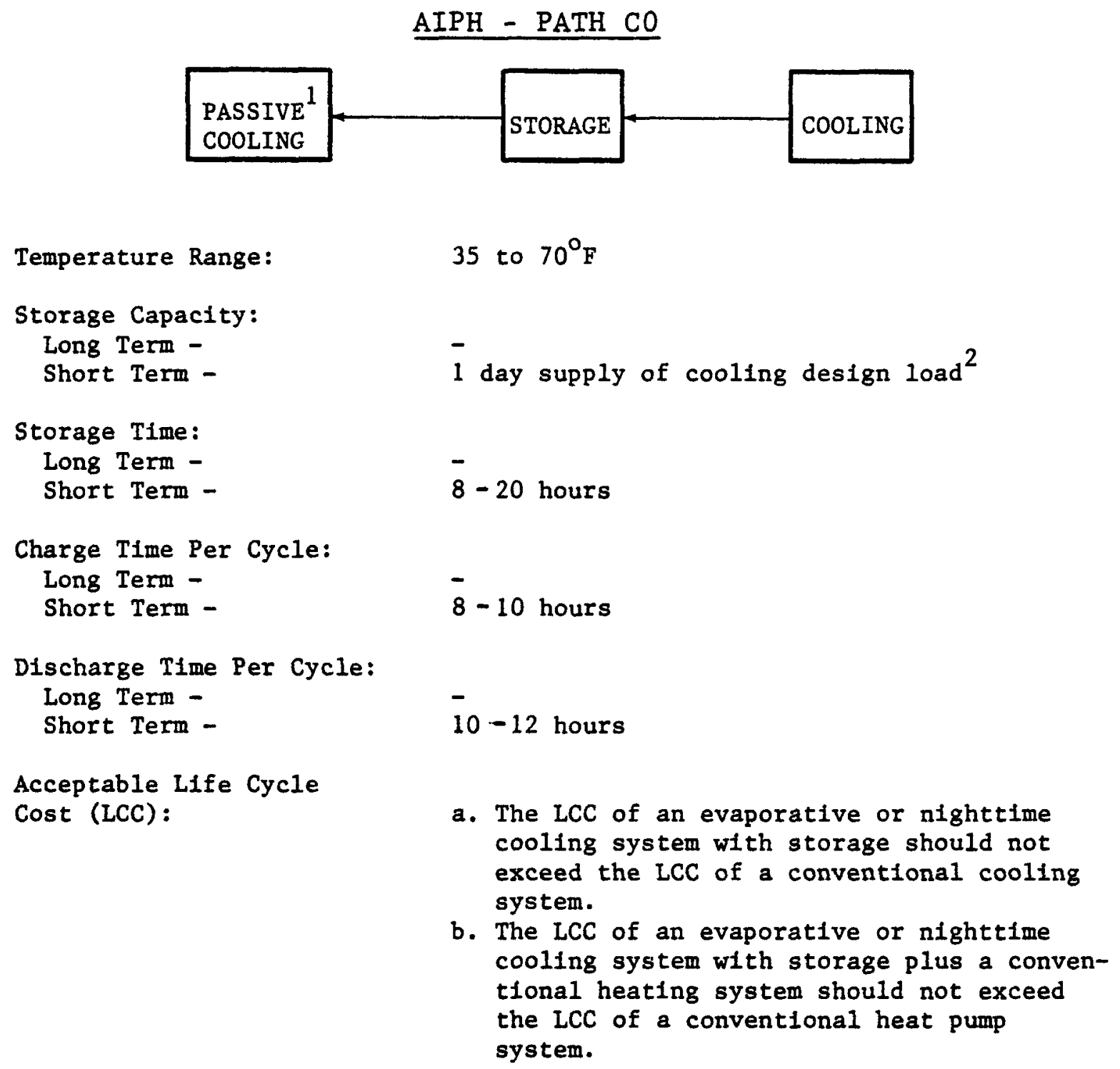

Temperature Range:

Storage Capacity:

Long Term -

Short Term -

Storage Time:

Long Term -

Short Term -

Charge Time Per Cycle:

Long Term -

Short Term -

Discharge Time Per Cycle:

Long Term -

Short Term -

Acceptable Life Cycle

Cost (LCC) :

35 to $70^{\circ} \mathrm{F}$

$\overline{1}$ day supply of cooling design load $^{2}$

$-$

$8-20$ hours

$8-10$ hours

$10-12$ hours

a. The LCC of an evaporative or nighttime cooling system with storage should not exceed the ICC of a conventional cooling system.

b. The LCC of an evaporative or nighttime cooling system with storage plus a conventional heating system should not exceed the LCC of a conventional heat pump system.

1. A passive cooling system may be an evaporative cooling system, a nighttime radiative cooling system, or a combination of both.

2. Cooling design load is selected at ASHRAE 5 percent sumer design conditions.

3. The weather conditions for effective evaporative and/or nighttime cooling are high dally outdoor temperature differentlal and low humidity. If the daytime humidity is low, an evaporative cooling system may work effectively. If the nighttime temperature is 10w, nighttime radiation combining with nighttime evaporation may be satisfactory. 


\begin{tabular}{|c|c|c|c|c|}
\hline \begin{tabular}{|c|} 
COLLECTOR \\
AND \\
HEAT \\
ENGINE/CHILLER
\end{tabular} & $\begin{array}{c}\text { HIGH } \\
\text { TEMPERATURE } \\
\text { STORAGE }\end{array}$ & $\begin{array}{c}\text { HEAT } \\
\text { ENGINE/CHILLER }\end{array}$ & $\begin{array}{c}\text { LOW } \\
\text { TEMPERATURE } \\
\text { STORAGE }\end{array}$ & $\begin{array}{c}\text { COOLING OR } \\
\text { REFRIGERATION }\end{array}$ \\
\hline
\end{tabular}

\section{AIPH - PATH CH}

$\begin{array}{lll} & \text { HIGH-TEMPERATURE STORAGE } & \text { LOW TEMPERATURE STORAGE } \\ \text { Temperature Range: } & 180^{\circ}-700^{\circ} \mathrm{F} & 0^{\circ} \text { to } 50^{\circ} \mathrm{F} \\ \text { Storage Capacity: } & \text { Depends on application } \\ \text { Storage Time: } & \text { Depends on application } \\ \text { Charge Time Per Cycle: } & \text { Depends on application } \\ \begin{array}{l}\text { Discharge Time Per } \\ \text { Cycle: }\end{array} & \text { Depends on application } \\ \begin{array}{l}\text { Acceptable Life Cycle } \\ \text { Cost (LCC): }\end{array} & \text { Depends on application }\end{array}$




\section{$\underline{A I P H}$ - PATH CP}

\begin{tabular}{|c|c|c|c|c|}
\hline & HIGH & & $\overline{\mathrm{LOW}}$ & \\
\hline HEAT & TEMPERATURE & & TEMPERATURE & \\
\hline COOLING & STORAGE & HEAT PUMP & STORAGE & COOLING \\
\hline
\end{tabular}

Similar to solar assisted heat pump paths Hla through Hle, except that:

- The process is reversed where the evaporator becomes the condenser and the condenser becomes the evaporator

- The high temperature storage becomes the low temperature storage, and the low temperature storage becomes the high temperature storage

- The heat pump may reject thermal energy directly to environment, or to storage and then dissipate the energy via collectors, fan-coil units or cooling towers. 